\title{
ANÁLISE DOS PADRÕES ESPACIAIS DE ÁRVORES EM QUATRO FORMAÇÕES FLORESTAIS DO ESTADO DE SÃO PAULO, ATRAVÉS DE ANÁLISES DE SEGUNDA ORDEM, COMO A FUNÇÃO K DE RIPLEY
}

\author{
ROBSON LOUIZ CAPRETZ
}

Dissertação apresentada à Escola Superior de Agricultura "Luiz de Queiroz", Universidade de São Paulo, para obtenção do título de Mestre em Ecologia de Agroecossistemas.

\author{
P I R A C I C A B A \\ Estado de São Paulo - Brasil \\ Outubro - 2004
}




\title{
ANÁLISE DOS PADRÕES ESPACIAIS DE ÁRVORES EM QUATRO FORMAÇÕES FLORESTAIS DO ESTADO DE SÃO PAULO, ATRAVÉS DE ANÁLISES DE SEGUNDA ORDEM, COMO A FUNÇÃO K DE RIPLEY
}

\author{
ROBSON LOUIZ CAPRETZ \\ Ecólogo
}

Orientador: Prof. Dr. JOÃO LUÍS FERREIRA BATISTA

Dissertação apresentada à Escola Superior de Agricultura "Luiz de Queiroz", Universidade de São Paulo, para a obtenção do título de Mestre em Ecologia de Agroecossistemas.

\author{
P I R A C I C A B A \\ Estado de São Paulo - Brasil \\ Outubro - 2004
}




\section{Dados Internacionais de Catalogação na Publicação (CIP) DIVISÃO DE BIBLIOTECA E DOCUMENTAÇÃO - ESALQ/USP}

\section{Capretz, Robson Louiz}

Análise dos padrões espacias de árvores em quatro formações florestais do Estado de São Paulo, através de análises de segunda ordem, como a função K de Ripley / Robson Louiz Capretz. - - Piracicaba, 2004.

$$
79 \text { p. : il. }
$$

Dissertação (Mestrado) - - Escola Superior de Agricultura Luiz de Queiroz, 2004.

Bibliografia.

1. Árvores florestais 2. Comunidades vegetais 3. Ecologia florestal 4. Estatística descritiva I. Título

CDD 634.94 


\section{DEDICATÓRIA}

a meus pais,

Emidio Capretz e Maria da Penha Matheus Capretz

(in memoriam) 


\section{AGRADECIMENTOS}

ao Prof. Dr. João Luis Ferreira Batista, pela orientação e exemplo.

a Fundação de Amparo à Pesquisa do Estado de São Paulo (FAPESP) pela bolsa de mestrado concedida (Processo 01/11825-3), e pelo suporte financeiro ao Projeto “Biota Parcelas Permanentes" (Processo 1999/09635-0).

a minha família.

a meus grandes amigos Décio Luis Semensatto Jr., Camila lotte Donatti e Ana Cláudia Mendes Malhado.

a Jefferson Lordelo Polizel, pela amizade e indispensável ajuda durante todo o mestrado.

a Ana Cristina Schling, pelo valoroso auxílio em Piracicaba.

a equipe do Biota Parcelas Permanentes.

a equipe do Laboratório de Métodos Quantitativos. 


\section{SUMÁRIO}

Página

LISTA DE FIGURAS . . . . . . . . . . . . . . . . . . . . . . . . . . . . . . . . . vi vi

LISTA DE TABELAS . . . . . . . . . . . . . . . . . . . . . . . . viii

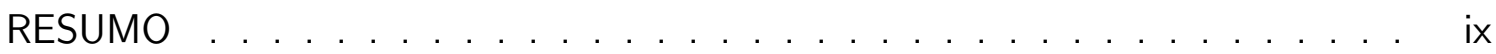

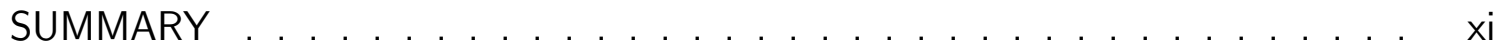

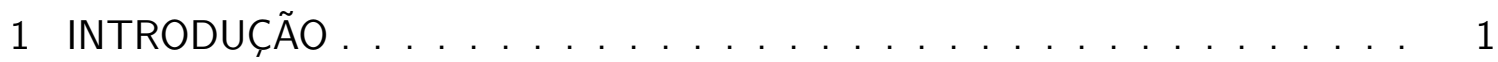

2 REVISÃO DA LITERATURA ........................ 4

2.1 Função K univariada . . . . . . . . . . . . . . . . . . . . . . . 5

2.2 Função K bivariada . . . . . . . . . . . . . . . . . . . . . . . . . . . . . 9

2.3 Aplicação da Função K de Ripley na literatura . . . . . . . . . . . . . . . . 13

3 PADRÃO ESPACIAL DAS ÁRVORES DE QUATRO FORMAÇÕES FLORESTAIS DO ESTADO DE SÃO PAULO . . . . . . . . . . . . . . . . . . . . 17

Resumo . . . . . . . . . . . . . . . . . . . . . . . . 17

Summary . . . . . . . . . . . . . . . . . . . . . . . . . . 18

3.1 Introdução . . . . . . . . . . . . . . . . . . . . . . . . . 18

3.2 Material e Métodos . . . . . . . . . . . . . . . . . . . . . . . . 20

3.3 Resultados . . . . . . . . . . . . . . . . . . . . . . . 23

3.4 Discussão . . . . . . . . . . . . . . . . . . . . . . . . . . . . . . . . . . . 36

3.5 Conclusões . . . . . . . . . . . . . . . . . . . . . . . . . . . . 38

4 PADRÃO ESPACIAL DAS ESPÉCIES ARBÓREAS EM QUATRO FORMAÇÕES FLORESTAIS DO ESTADO DE SÃO PAULO . . . . . . . . . . . . . 40

Resumo . . . . . . . . . . . . . . . . . . . . . . 40 
Summary . . . . . . . . . . . . . . . . . . . . . 41

4.1 Introdução . . . . . . . . . . . . . . . . . . . . . . 41

4.2 Material e Métodos . . . . . . . . . . . . . . . . . . . 43

4.3 Resultados . . . . . . . . . . . . . . . . . . . . . . . 46

4.4 Discussão . . . . . . . . . . . . . . . . . . . . . . . . . . 62

4.5 Conclusões . . . . . . . . . . . . . . . . . . . . . . . . . . . 68

5 CONCLUSÕES GERAIS . . . . . . . . . . . . . . . . . . . . . . 69

Referências Bibliográficas . . . . . . . . . . . . . . . . . . . . . . . . . . 72 


\section{LISTA DE FIGURAS}

Página

1 Comparação entre $K(s)$ e sua transformada $L(s)$, para um mesmo conjunto de dados. . . . . . . . . . . . . . . . . . . . . . . . . . . 10

2 Padrão espacial observado para as árvores em cada parcela permanente . . . 25

3 Histogramas para classes de diâmetro para as árvores de cada parcela perma-

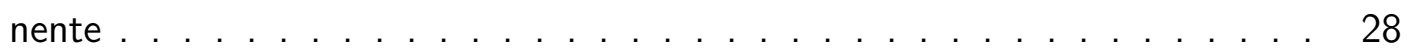

4 Análise do padrão espacial das árvores segundo classes de diâmetro no Cerradão 29

5 Análise do padrão espacial das árvores segundo classes de diâmetro na Floresta Estacional . . . . . . . . . . . . . . . . . . . . . . . . . . . . 31

6 Análise do padrão espacial das árvores segundo as classes de diâmetro na Floresta Ombrófila . . . . . . . . . . . . . . . . . . . . . . . . 32

7 Análise do padrão espacial das árvores segundo as classes de diâmetro na Restinga . . . . . . . . . . . . . . . . . 33

8 Função $\mathrm{K}$ bivariada calculada entre as classes de tamanho nas quatro parcelas

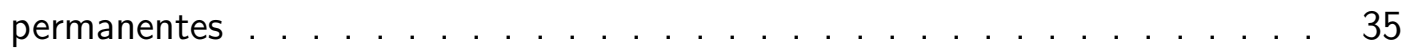

9 Padrão espacial observado para as espécies de maior abundância no Cerradão 49

10 Padrão espacial observado para as espécies de maior abundância na Floresta Estacional . . . . . . . . . . . . . . . . . . . . . . 52

11 Padrão espacial observado para as espécies de maior abundância na Floresta

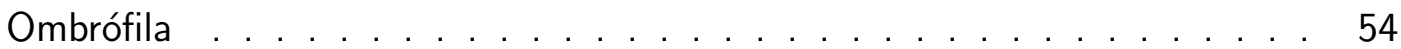

12 Padrão espacial observado para as espécies de maior abundância na Restinga 57

13 Função K bivariada calculada para as espécies estudadas nas quatro parcelas permanentes 
14 Padrão espacial observado para as espécies coincidentes entre as quatro parcelas permanentes ........................ 61 


\section{LISTA DE TABELAS}

Página

1 Classes de diâmetro para as árvores em cada área de estudo . . . . . . . . . 27

2 Espécies de maior densidade no Cerradão . . . . . . . . . . . . . . . . . . . 47

3 Espécies de maior densidade na Floresta Estacional . . . . . . . . . . . . . . . 50

$4 \quad$ Espécies de maior densidade na Floresta Ombrófila . . . . . . . . . . . . . . 53

5 Espécies de maior densidade na Restinga . . . . . . . . . . . . . . . . . . 55 


\title{
ANÁLISE DOS PADRÕES ESPACIAIS DE ÁRVORES EM QUATRO FORMAÇÕES FLORESTAIS DO ESTADO DE SÃO PAULO, ATRAVÉS DE ANÁLISES DE SEGUNDA ORDEM, COMO A FUNÇÃO K DE RIPLEY
}

\author{
Autor: ROBSON LOUIZ CAPRETZ \\ Orientador: Prof. Dr. JOÃO LUÍS FERREIRA BATISTA
}

RESUMO

O padrão espacial das árvores em uma floresta é influenciado por variáveis abióticas e bióticas. Entre as principais variáveis abióticas estão o relevo, a disponibilidade de luz, nutrientes e água, e a caracterização do solo. Entre as principais variáveis bióticas estão os processos dependentes da densidade, tais como a competição intraespecífica e interespecífica, a herbivoria, a ocorrência de doenças, a fenologia e dispersão de sementes. Desse modo, investigar o padrão espacial das árvores, segundo suas classes de tamanho, e segundo suas espécies mais abundantes, pode fornecer evidências sobre a estrutura da comunidade vegetal. A descrição do padrão espacial das árvores e das espécies mais abundantes em diferentes formações florestais foi realizada usando ferramentas estatísticas mais apropriadas para investigar mapas das árvores. A Função $\mathrm{K}$ de Ripley tem como principais vantagens a possibilidade de detectar o padrão espacial em diversas escalas 
de distâncias simultaneamente, e avaliar a dependência espacial entre grupos de árvores. Os padrões observados foram comparados com os modelos de Completa Aleatoriedade Espacial, para a função univariada, e de Completa Independência Espacial, para a função bivariada. Diferentes formações florestais, típicas da região sudeste do Brasil, foram comparadas neste estudo: Floresta Ombrófila Densa Submontana, Savana Florestada (Cerradão), Floresta Estacional Semidecidual e Formação Pioneira com Influência Marinha (Restinga). Esta dissertação de mestrado integra o Projeto "Diversidade, dinâmica e conservação em florestas do Estado de São Paulo: 40 ha de parcelas permanentes", do Programa Biota da FAPESP. Neste projeto, uma parcela de 10,24 ha foi montada em cada formação florestal, e todas as árvores com circunferência na altura do peito a partir de $15 \mathrm{~cm}$ foram medidas, mapeadas e identificadas. Os resultados obtidos neste estudo ressaltam o caráter agregado em florestas tropicais, uma vez que o padrão agregado foi observado em todas as florestas estudadas. As árvores do Cerradão e da Restinga apresentaram padrões muito próximos, com uma agregação definida até uma certa escala de distâncias. Para a Floresta Ombrófila, o padrão agregado foi significativo em toda a escala de distâncias. Na Floresta Estacional, tendência à aleatoriedade foi observada, embora uma agregação significativa tenha sido notada para curtas distâncias. A análise do padrão espacial segundo classes de tamanho mostrou que as primeiras classes possuem, em geral, padrões agregados significativos, enquanto para as classes seguintes o padrão aleatório foi predominante. Em linhas gerais, o padrão espacial das espécies acompanhou o padrão geral de cada formação florestal. O padrão das espécies dominantes é sempre muito semelhante ao padrão espacial da floresta como um todo. Como era esperado, as espécies dominantes desempenham importante papel na ocupação do espaço horizontal em tais florestas, contribuindo de modo decisivo para a caracterização do padrão espacial da comunidade. Espécies que ocorreram em diferentes florestas apresentaram pequenas diferenças no seu padrão espacial, ressaltando-se assim a importância da sua autoecologia e dos processos ecológicos intrínsecos a cada comunidade. 


\title{
SPATIAL PATTERN ANALYSIS OF TREES OF FOUR FOREST COMMUNITIES IN SOUTHEASTERN BRAZIL, USING RIPLEY'S K FUNCTION
}

\author{
Author: ROBSON LOUIZ CAPRETZ \\ Adviser: Prof. Dr. JOÃO LUÍS FERREIRA BATISTA
}

SUMMARY

Tree spatial patterns are influenced by abiotic and biotic environment. Among the main abiotic factors are topography, light, nutrients, soil and water availability. Among biotic factors are density-dependent processes, as intraespecific and interespecific competition, herbivory, pathogens, phenology and seed dispersion. Investigation of tree spatial patterns, patterns in size classes, and dominant species patterns can show evidences about the structure of plant communities. Description of trees spatial pattern was made using the most appropriate statistical tools for mapped data. Ripley's K Function has as its main attributes the power to detect the spatial patterns in different distance scales simultaneously, and to investigate spatial independence among groups of trees. Observed patterns were compared to Complete Spatial Randomness model, in univariate function, and to Complete Spatial Independence model, in bivariate function. 
Different forests, typical from Southeastern Brazil, were compared in this study: Forest Savanna (Cerradão), Dense Rain Forest, Seasonal Semideciduous Forest and Restinga. This mastership thesis is part of Project "Diversity, dynamics and conservation in forests in the State of São Paulo: 40 ha of permanent plots", from FAPESP Biota Program. In this project, one permanent plot of $10.24 \mathrm{ha}$ was located in each forest stand, and all its trees with circunference at breast height equals $15 \mathrm{~cm}$ or higher were measured, mapped and identified. The results obtained in this study shows the aggregated pattern as the most common pattern in tropical forests. The trees spatial pattern in Cerradão and Restinga were very similar, aggregation was observed in the same distance scales. For the Dense Rain Forest, the spatial pattern was significant for all the distance scales. In Semidecidous Forest, a tendency towards randomness was observed, but a significant aggregation appeared for short distances. The spatial analysis for size classes showed that the newer classes have aggregated patterns, while the following classes have random ones. The dominant species spatial patterns were close to the general patterns of its community. As expected, dominant species play important rules in characterizing the horizontal pattern of their forests. Common species between different forests showed small differences in its spatial pattern, indicating the importance of its autoecology and the intrinsic ecological processes of each community. 


\section{INTRODUÇÃO}

O padrão espacial de árvores é uma questão chave para estudos de ecologia florestal. O nível de organização espacial das árvores no ambiente depende de diversos processos ecológicos e características próprias de cada ambiente, de modo que a meIhor compreensão deste quadro fornece subsídios importantes para o conhecimento sobre formações florestais.

Conhecer o padrão espacial de espécies-chave é vital para entender como dada espécie usa os recursos disponíveis, de que forma este recurso é importante, e sua função no sucesso do estabelecimento e reprodução desta espécie (Condit et al. 2000). Especialmente em florestas tropicais, a questão espacial adquire caráter ainda mais relevante, uma vez que a alta diversidade de tais biomas tem estreita relação com suas densidades populacionais, e por conseqüência, com a proximidade entre seus indivíduos (John et al. 2002). Entre as teorias mais importantes em ecologia florestal, duas, em especial, merecem destaque, pois tratam da biodiversidade tropical com ênfase na questão espacial: os conceitos formulados por Janzen (1970) e Connell (1978), na chamada hipótese de fuga, e por Hubbell (1979).

Tais conceitos incorporam processos ecológicos da dinâmica de florestas tropicais, como dispersão de sementes, processos dependentes da densidade (especialmente competição intraespecífica e interespecífica), herbivoria, recrutamento e dinâmica de clareiras (Clark \& Clark 1984, Sterner et al. 1986, Kenkel et al. 1988, Condit et al. 1992, Collins \& Klahr 1991, Batista 1994, Barot et al. 1999, Grau 2000, Harms et al. 2001). Diversos aspectos abióticos também são freqüentemente discutidos ao explicar a biodiversidade de florestas tropicais, e como conseqüência, o arranjo espacial das árvores: são citados principalmente a disponibilidade de habitats, nutrientes e água no solo, relevo 
e incidência de luz (Getis \& Franklin 1986, Armesto et al. 1986, Harms et al. 2001, Day et al. 2003, Schwarz et al. 2003, Barot et al. 2003).

A descrição do padrão espacial da comunidade como um todo, incluindo todas as árvores e espécies, pode fornecer evidências sobre o impacto do meio abiótico sobre a floresta. Fatores limitantes acentuados ou barreiras geográficas, por exemplo, afetam toda a comunidade de modo semelhante. De modo complementar, o estudo do padrão espacial e da autoecologia de espécies-chave pode refinar o conhecimento sobre o funcionamento de uma formação florestal, especialmente sobre os processos ecológicos mais influentes.

Em linhas gerais, estudos sobre ecologia florestal têm como alicerces fitodemografia, composição e estrutura da comunidade, genética, fenologia e o padrão espacial propriamente dito (Rees et al. 2001). Estudos a longo prazo, especialmente aqueles envolvendo o monitoramento da vegetação ao longo do tempo, vêm sendo desenvolvidos recentemente em diferentes florestas tropicais (Armesto et al. 1986, Condit et al. 2000). Neste contexto, merece destaque o Projeto "Diversidade, dinâmica e conservação em florestas do Estado de São Paulo: 40 ha de parcelas permanentes", do Programa Biota da Fundação de Amparo à Pesquisa do Estado de São Paulo (FAPESP), que visa desenvolver estudos a médio e longo prazo em quatro das mais representativas formações florestais da região sudeste do Brasil: Floresta Ombrófila Densa Submontana, Formação Pioneira com Influência Marinha (Restinga), Savana Florestada (Cerradão) e Floresta Estacional Semidecidual.

O presente estudo insere-se no Projeto "Biota Parcelas Permanentes", e consiste na primeira análise do padrão espacial da vegetação em cada uma das formações florestais em questão. O estudo busca descrever a organização espacial das árvores em cada uma das parcelas permanentes, procurando observar indícios de como os processos ecológicos e a caracterização de cada ambiente influenciam o arranjo espacial das árvores nas florestas estudadas.

De modo geral, as questões que nortearam este estudo foram: (1) investigar o padrão espacial de quatro formações florestais do sudeste do Brasil, discutindo 
quais são os padrões predominantes, (2) analisar o padrão espacial segundo classes de diâmetro, (3) observar o padrão espacial das espécies dominantes em cada bioma, e verificar se o seu padrão é coerente com o padrão geral da floresta, e (4) investigar o padrão espacial das árvores das espécies comuns a formações florestais distintas, de modo a observar de que forma tais espécies respondem a diferentes ambientes.

Esta dissertação de mestrado segue o formato de artigos científicos. Em razão do potencial do uso de análises de segunda ordem, como a função K de Ripley, para analisar o padrão espacial de árvores (Armesto et al. 1986, Haase et al. 1995, Batista \& Maguire 1998, Grau 2000), atenção espacial foi concedida à apresentação de suas bases teóricas e sua aplicação em estudos recentes, no capítulo de Revisão Bibliográfica.

O primeiro artigo (capítulo 3) refere-se às análises do padrão espacial geral da comunidade. Neste capítulo, todas as árvores encontradas nas parcelas permanentes foram incluídas, sem distinção entre espécies. As principais questões abordadas foram a relação espacial entre as árvores segundo seu tamanho, e discussões a respeito do padrão espacial em cada formação florestal.

No segundo artigo (capítulo 4) são apresentadas análises do padrão espacial das quatro espécies de maior abundância em cada formação florestal, as relações de dependência espacial entre elas, e análises espaciais referentes às espécies comuns a mais de uma formação florestal. Tais análises devem contribuir para discutir a autoecologia das espécies, suas diferentes respostas a ambientes distintos e sua importância na caracterização da formação florestal como um todo. 


\section{REVISÃO DA LITERATURA}

A função K de Ripley (1977) é uma estatística descritiva do padrão espacial, também chamada de "análise de segunda ordem reduzida" pois ela se baseia em medidas de segunda ordem (Ripley 1981). É uma das ferramentas estatísticas mais apropriadas para análises do padrão espacial de florestas, sobretudo quando os dados são apresentados soba forma de mapas de vegetação, com todas suas árvores com suas coordenadas conhecidas.

As principais vantagens do método são ele permitir a detecção do padrão espacial em diferentes escalas de distâncias simultaneamente, permitir que o padrão espacial observado seja comparado com modelos conhecidos, investigar o padrão segundo altura, diâmetro ou identificação botânica, através da função K "marcada", e investigar o nível de independência espacial entre dois grupos quaisquer de árvores, como espécies diferentes ou árvores de diferentes tamanhos.

Se compararmos a função $\mathrm{K}$ com outros métodos freqüentemente utilizados na ecologia florestal, comprovamos seu potencial de uso e sua robustez estatística. Métodos baseados em distâncias ou área, que são os mais comuns, carregam em sua essência "simplificações" da realidade, uma vez que tratam apenas da simples contagem de indivíduos dentro de parcelas ou da procura pelo primeiro vizinho mais próximo da mesma espécie (Ripley 1978). Desse modo, muita informação é perdida nas análises espaciais, uma vez que tais métodos só conseguem detectar o padrão espacial naquela escala particular em que os dados foram coletados, comoo tamanho da parcela ou a distância entre os pontos (Sterner et al. 1986).

Ao se estudar o padrão espacial é necessário distingüir entre o padrão espacial observado, isto é, o mapa das árvores, e o processo espacial que gerou o padrão 
espacial. Um mapa de árvores específico deve ser entendido como uma única realização particular (o padrão espacial observado) de um processo espacial, resultante da interação de inúmeros processos ecológicos, que poderiam gerar infinitos padrões espaciais diferentes. Logicamente, todos os padrões gerados pelo mesmo processo possuirão características semelhantes. A função $\mathrm{K}$ é uma forma de descrever tais características.

A função K de Ripley computa todas as distâncias entre todas as árvores em um mapa para investigar seu padrão. De modo simplificado, o procedimento consiste em um círculo de raio $s$ centrado em cada árvore, e onde o número de vizinhos presentes dentro da área deste círculo é contado (Haase 1995, Anjos et al. 1998, Kuuluvainen \& Rouvinen 2000). Variando o raio $s$ é possível detectar o padrão espacial em diferentes escalas. Esta flexibilidade em relação à escala de distâncias é o que difere substancialmente a função $\mathrm{K}$ de outras ferramentas mais utilizadas.

A análise é feita graficamente, para facilitar a visualização dos desvios em relação à hipótese nula, através de um gráfico cujas abcissas representam $s$ e as ordenadas a função transformada $L(s)$ da função K (Ripley 1979, Getis \& Franklin 1987, Batista 1994, Kuuluvainen \& Rouvinen 2000, Pélissier \& Goreaud 2001).

\subsection{Função $\mathrm{K}$ univariada}

No presente estudo, a hipótese nula, para a função univariada, é a de Completa Aleatoriedade Espacial (CAE), testada através de inúmeras simulações Montecarlo, simulando padrões espaciais aleatórios, construindo assim envelopes de confiança, através dos maiores e menores valores calculados da função $\mathrm{K}$ para cada simulação e para cada escala de distâncias. Se os valores observados estiverem dentro de tais envelopes, que oscilam ao redor do valor zero da transformada $L(s)$, é possível dizer que o padrão espacial é aleatório. Para valores fora dos envelopes a hipótese nula é rejeitada: se os valores forem positivos o padrão é agregado, e se forem negativos o padrão é regular. 
Formalmente, a função $\mathrm{K}$ pode ser definida como:

$$
K(s)=\frac{2 \pi}{\lambda^{2}} \int_{0}^{s} \lambda_{2}(t) t d t
$$

A medida de primeira ordem é representada por uma função $\lambda_{1}(x)$, que é a função de intensidade de primeira ordem. Ela indica a intensidade do processo na localização $x$. No caso do plano $\left(\Re^{2}\right)$ uma localização é definida por um sistema de coordenadas simples: $x=\left(x_{1}, x_{2}\right)$.

Ao se gerar um padrão no plano, a intensidade de primeira ordem do processo pode ser interpretada como a densidade do padrão numa localização particular. Na definição da função K:

$$
\lambda_{1}(x) \equiv \lambda
$$

ou seja, assume-se que a intensidade de primeira ordem do processo que gerou o padrão espacial observado é constante (e igual a $\lambda$ ) em toda a área de estudo. Essa pressuposição é chamada de pressuposição da estacionaridade do processo.

A função $\mathrm{K}$, ao combinar as funções de intensidade de primeira e segunda ordem, resulta numa função descritiva do padrão espacial com interpretações mais diretas:

$\lambda K(s)$ é o número esperado de árvores a uma distância igual ou menor que $s$ de uma árvore arbitrária qualquer

$\lambda^{2} K(s)$ é o número esperado de pares de árvores cuja distância entre as árvores é no máximo $s$

Ambas as interpretações implicam que a função $K$ é uma função acumulada, o que deve ser considerado na interpretação das suas estimativas.

Quando se estuda o padrão espacial com base num mapa de árvores, a aleatoriedade do padrão é definida pela Completa Aleatoriedade Espacial (CAE), isto é, o processo que gerou o padrão é aleatório em qualquer escala espacial. 
Na CAE, também chamada de Processo Poisson, as funções de intensidade são constantes:

$$
\begin{aligned}
\lambda_{1}(x) & \equiv \lambda, \\
\lambda_{2}(x, y) & =\lambda_{2}(\|x-y\|)=\lambda_{2}(s) \equiv \lambda^{2}
\end{aligned}
$$

Como conseqüência, a função $K$ na CAE fica

$$
\begin{aligned}
K(s) & =\frac{2 \pi}{\lambda^{2}} \int_{0}^{s} \lambda_{2}(t) t d t=\frac{2 \pi}{\lambda^{2}} \int_{0}^{s} \lambda^{2} t d t \\
K(s) & =\pi s^{2}
\end{aligned}
$$

Assim a função $\mathrm{K}$ pode ser facilmente utilizada para se testar a hipótese de aleatoriedade (CAE).

\section{Estimativa da Função K de Ripley}

Uma questão tem merecido atenção na literatura pertinente ao uso de análises de segunda ordem para investigar o padrão espacial de pontos: os métodos de correção para as árvores próximas à borda do mapa. Uma vez que a função $\mathrm{K}$ é cumulativa e computa as distâncias entre todos os pontos, as árvores próximas à borda do mapa não podem ser interpretadas simplesmente como se não houvesse vizinhos ao seu lado. Estes pontos existem, mas não aparecem por estarem fora dos limites do mapa. Assim, o número de árvores vizinhas àquelas próximas dos limites do mapa (as bordas ou bordaduras) seria mais baixo do que para as demais, e este fato poderia causar um viés no cálculo do estimador da função (Haase 1995). Todo mapa de árvores é construído em uma região de estudo finita. A definição da função $K$, entretanto, é baseada no conceito geométrico do plano, que é ilimitado e infinito, designado por $\Re^{2}$. Evidentemente, quanto maior a escala, maior seria o viés do estimador.

Diversos autores, como Ripley (1977), Goreaud \& Pélissier (1999) e Stoyan

\& Stoyan (2000), mostraram-se preocupados com tal questão. Goreaud \& Pélissier (1999) revisaram com propriedade as fórmulas freqüentemente utilizadas para a correção 
do efeito da borda do mapa. O estimador da função $\mathrm{K}$ com a correção proposta por Ripley (1977), baseado em correção isotrópica de bordadura, é o método escolhido e utilizado nesta pesquisa:

$$
\widehat{K}(s)=\frac{1}{\widehat{\lambda} n} \sum_{i=1}^{n} \sum_{\substack{j=1 \\ i \neq j}}^{n} w_{I}^{-1}\left(\mathbf{x}_{i}, \mathbf{x}_{j}\right) I\left(\left\|\mathbf{x}_{i}-\mathbf{x}_{j}\right\|<s\right)
$$

onde

$n$ é o número de árvores na região de estudo

$\mathbf{x}_{i}$ e $\mathbf{x}_{j}$ são as coordenadas dos pontos no mapa

$\left\|\mathbf{x}_{i}-\mathbf{x}_{j}\right\|$ é a distância euclidiana entre as localizações $\mathbf{x}_{i}$ e $\mathbf{x}_{j}$

$s$ é um vetor arbitrário de distâncias

$\widehat{\lambda}=n /|A|$ é o número de árvores dividido pela área da região de estudos, sendo um estimador não viciado da intensidade do processo

$w_{I}\left(\mathbf{x}_{i}, \mathbf{x}_{j}\right)$ é a função de correção isotrópica de bordadura, a qual representa a proporção da circunferência com centro em $\mathbf{x}_{i}$ e com raio $\left\|\mathbf{x}_{i}-\mathbf{x}_{j}\right\|$ que está fora da região de estudo; essa função é definida para qualquer polígono convexo

$I(U)$ é uma função indicadora que assume o valor 1 (um) sempre que a condição $U$ for verdadeira, e zero quando a condição for falsa

Em regiões de estudo retangulares, o estimador de Ripley é um estimador não viciado da função K para distâncias inferiores à metade do menor lado do retângulo (Diggle 1983). Por este motivo, a escala de distâncias utilizada neste estudo vai de 1 a $160 \mathrm{~m}$, uma vez que cada parcela permanente tem $320 \times 320 \mathrm{~m}$. A correção da bordadura em qualquer estimador da função $K$ impõe uma restrição sobre a amplitude da escala espacial (ou distância $s$ máxima) em que a função pode ser adequadamente estimada. 
Para facilitar a visualização dos resultados, a função K é transformada para a função $L(s)$ :

$$
\widehat{L(s)}=\sqrt{\widehat{K(s)} / \pi}-s
$$

Para se testar a hipótese nas diversas escalas de distâncias $s$, um gráfico é construído tendo nas ordenadas a função $L(s)$ e nas abcissas as distâncias $s$ (figura 1 ). Importante notar a clareza que esta transformação propicia à análise gráfica, em relação à função $\mathrm{K}$ não transformada.

Se o padrão for completamente aleatório, a função $L(s)$ se apresentará como uma linha horizontal sobre o eixo das abcissas. A agregação num padrão espacial se refletirá em um número de árvores maior que o esperado pela CAE e, conseqüentemente, a função assumirá valores positivos, distanciando-se do eixo das abcissas. Se um padrão apresentar regularidade na localização das árvores, o número de árvores será menor do que o esperado pela CAE e a função $L(s)$ assumirá valores negativos.

Esta transformação é realizada tanto para a função univariada quanto para a bivariada.

\subsection{Função $\mathrm{K}$ bivariada}

A função $\mathrm{K}$ também pode ser aplicada para estudar a relação de dependência ou independência espacial entre dois processos (Diggle 1983, Batista 1994, Barot et al. 1999, Coomes et al. 1999). Também chamada de função K bivariada ou "cruzada", ela torna possível investigar a relação espacial entre dois grupos de árvores, como por exemplo duas espécies competidoras em potencial, ou as árvores de duas classes de tamanho distintas. Este teste avalia a independência entre grupos gerados por diferentes processos (Barot et al. 1999). Envelopes de confiança são gerados, e sua interpretação é análoga à função univariada. Valores positivos da função indicam tendências em direção à agregação ou associação, e valores negativos remetem à regularidade ou repulsão. Dentro dos envelopes de confiança aceita-se a hipótese nula, de Completa Independência Espacial (CIE). 
A função $\mathrm{K}$ cruzada é formalmente definida como:

$$
K_{12}(s)=\frac{2 \pi}{\lambda_{1} \lambda_{2}} \int_{0}^{s} \lambda_{12}(t) t d t
$$

onde

$\lambda_{1}$ é a intensidade de primeira ordem das árvores do primeiro conjunto (constante)

$\lambda_{2}$ é a intensidade de primeira ordem das árvores do segundo conjunto (constante)

$\lambda_{12}(s)$ é a função de intensidade de segunda ordem para o processo bivariado, centrada nas árvores do primeiro conjunto

A hipótese sendo testada nesse caso já não é a $C A E$, mas a hipótese da Completa Independência Espacial entre os processos. Não se fala mais em agregação versus regularidade, mas em atração versus repulsão entre os processos.
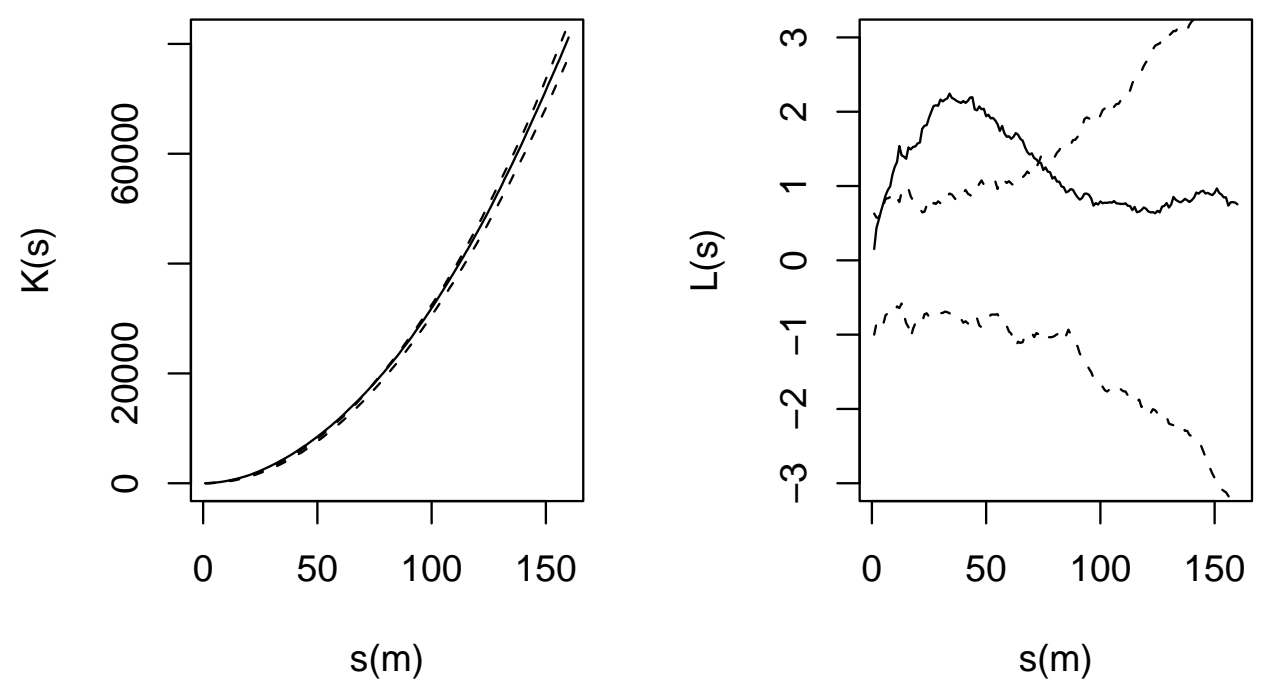

Figura 1 - Comparação entre $K(s)$ e sua transformada $L(s)$, para um mesmo conjunto de dados. 
Essa interpretação sugere que as funções $\mathrm{K}$ cruzadas $K_{12}(s)$ e $K_{21}(s)$ podem ser diferentes. Entretanto, num processo bivariado estacionário elas são iguais (Diggle 1983).

Quando o processo bivariado é composto de dois processos univariados completamente independentes a função de intensidade de segunda ordem do processo bivariado se torna:

$$
\lambda_{12}(s) \equiv \lambda_{1} \lambda_{2}
$$

e a função $\mathrm{K}$ cruzada se torna igual ao caso univariado: $K_{12}(s)=\pi s^{2}$.

Para estimar a função K cruzada utiliza-se o estimador de Ripley de modo análogo ao caso univariado:

$$
\tilde{K}_{12}(s)=\frac{1}{\widehat{\lambda}_{1} \widehat{\lambda}_{2}} \sum_{i=1}^{n_{1}} \sum_{j=1}^{n_{2}} w_{I}^{-1}\left(\mathbf{x}_{1 i}, \mathbf{x}_{2 j}\right) I\left(\left\|\mathbf{x}_{1 i}-\mathbf{x}_{2 j}\right\|<s\right)
$$

onde:

$\lambda_{1}=n_{1} /|A|$ é o estimador não viciado da intensidade do primeiro processo

$\lambda_{2}=n_{2} /|A|$ é o estimador não viciado da intensidade do segundo processo

$w_{I}\left(\mathbf{x}_{1 i}, \mathbf{x}_{2 j}\right)$ é a correção isotrópica de bordadura centrada nas árvores do primeiro processo

$I(U)$ é a função indicadora centrada nas árvores do primeiro processo

Para o caso de se assumir a pressuposição de um processo bivariado estacionário, Lotwick \& Silverman (1982) sugeriram o seguinte estimador para função K bivariada:

$$
\widehat{K}_{12}(s)=\frac{n_{1} \tilde{K}_{12}(s)+n_{2} \tilde{K}_{21}(s)}{n_{1}+n_{2}}
$$

É importante salientar que a observação de uma atração entre dois grupos de árvores não implica diretamente em qualquer relação entre causa e efeito, tampouco relações mutualísticas ou alelopáticas entre as espécies arbóreas; portanto, observar, 
através da função $\mathrm{K}$ bivariada, que dois grupos possuem dependência espacial não significa necessariamente que a presença de um grupo influencia ecologicamente o outro. É possível, a partir desse ponto, investigar então se há uma afinidade entre os nichos ecológicos, ou mesmo se uma dada espécie fornece condições de sombreamento, proteção contra herbívoros ou qualquer outra relação de cooperação. Mas a simples observação não basta para definir, sem informações ecológicas como complemento, que a afinidade ecológica exista (Legendre 1993).

\section{Envelopes de Confiança}

Para comparar o padrão espacial observado com modelos, faz-se necessário construir envelopes de confiança. Os modelos testados neste estudo são os de Completa Aleatoriedade Espacial (CAE), para o caso univariado, e de Completa Independência Espacial (CIE), para o caso bivariado.

Na função K univariada, os envelopes de confiança são construídos através de simulações Montecarlo. Um padrão espacial completamente aleatório é simulado com base no número de árvores verificadas no campo. Para cada mapa resultante, calcula-se a função K. Após mil simulações do padrão espacial segundo o modelo de CAE, e após o cálculo da função K para cada simulação, os valores máximos e mínimos de cada cálculo são armazenados para cada distância $s$. Tais valores são utilizados para obter os limites inferior e superior do envelope.

Para a função $\mathrm{K}$ bivariada, utilizou-se a técnica de toroidal shifts usada por Barot et al. (1999). A hipótese de independência espacial da função K bivariada é testada convertendo o mapa de estudo em um toróide, e então aleatoriamente traduzindo um dos padrões na direção dos eixos em relação um ao outro. Maiores informações sobre este método para construção de envelopes de confiança para a função K bivariada são encontradas em Ripley (1981) e Cunha (2003). 


\subsection{Aplicação da Função K de Ripley na literatura}

A utilização da função K de Ripley vem aumentando em estudos em ecologia florestal nos últimos anos. O crescente interesse na sua utilização é conseqüência das suas vantagens em relação a outros métodos. Ainda que a maioria dos estudos aplicando a análise seja em florestas temperadas, novos artigos na literatura empregando a função $\mathrm{K}$ de Ripley em florestas tropicais começam a tornar-se mais freqüentes.

Dale \& Powell (2001) realizaram um estudo teórico sobre métodos de segunda ordem e suas variações, e propuseram um novo método para detecção do padrão espacial muito semelhante à função K: tal análise é calculada com o número de pontos em círculos de raios definidos, mas tal método difere do método de Ripley (1977) pelo fato de que os círculos não são centrados em cada planta, e sim através de uma triangulação entre as árvores. Os autores aplicaram o método a diversos conjuntos de dados, e ressaltaram por fim a sua utilidade, especialmente para investigar as relações entre plântulas e adultos.

Haase (2001) estudou os efeitos de isotropia e anisotropia (presença ou ausência de simetria espacial, efeitos de direção no padrão espacial) quando ocorre associação ou repulsão entre espécies. O autor propôs algumas mudanças no cálculo da função K, e usou seu método modificado para os dados da vegetação da região de Andaluzia, na Espanha (Haase et al. 1996, Haase et al. 1997).

Mudanças em análises de segunda ordem também foram propostas e testadas por Getis \& Franklin (1987), estudando o arranjo espacial de Pinus ponderosa no norte da Califórnia, Estados Unidos.

Ainda em florestas temperadas, Kenkel (1988) testou a mortalidade ao acaso verificando se a distribuição dos sobreviventes de Pinus baskiana divergia daquela esperada em processos aleatórios. Indicações da ocorrência de mortalidade dependente da densidade foram observadas a partir do padrão regular dos sobreviventes e do padrão agregado das árvores mortas. Em estudo posterior, Kenkel (1993) estudou a dependência markoviana em matas ciliares canadenses, também aplicando a função K.

He \& Duncan investigaram a dependência em relação à densidade em floresta dominada por Pseudotsuga menziesii no Canadá. Assim como bem observou Kenkel 
(1988), fortes indícios de competição intraespecífica e interespecífica foram observados, uma vez que a sobrevivência era significativamente maior em grupos menos densos, dando origem a padrões regulares para os sobreviventes.

Leemans (1991) estudou o padrão espacial de plântulas, juvenis e adultos em duas florestas dominadas por Picea abies na Suécia. Para o autor, a abertura de clareiras no dossel da floresta favorecia o desenvolvimento de estágios intermediários, explicando o padrão agregado para árvores de tamanhos intermediários, enquanto padrões aleatórios foram observados para plântulas e adultos. Resultados semelhantes foram observados por Edman \& Jonsson (2001), também em florestas boreais na Suécia.

Kuuluvainen \& Rouvinen (2000) estudaram a regeneração de uma floresta boreal de Pinus sylvestris na Finlândia, em duas áreas com histórias diferentes de exposição ao fogo. Indícios fortes de competição intraespecífica foram observados através da função $\mathrm{K}$ bivariada, e padrões agregados reforçaram a idéia de que a regeneração em tais florestas aproveita-se das clareiras abertas pelos incêndios na floresta.

Busing (1988), aplicando a função K para estudar o padrão espacial das árvores segundo seu tamanho, em uma floresta montana temperada na América do Norte, encontrou padrões regulares para adultos e agregados para jovens. A função bivariada salientou efeitos de inibição entre jovens e adultos, fortalecendo as evidências da competição intraespecífica e da síndrome de dispersão das espécies encontradas.

Miyadokoro et al. (2003) estudaram o padrão espacial de uma floresta subalpina de coníferas no Japão. Seu objetivo era verificar as diferentes estratégias de crescimento das grandes árvores refletiam-se na sua distribuição e na estrutura das espécies. Os autores salientaram a importância das condições microclimáticas, do solo e da presença de clareiras para o padrão espacial observado.

Pélissier \& Goreaud (2001), comparando o padrão de uma floresta temperada submetida a manejo florestal na França, e de uma floresta úmida sempre verde na Índia, destacaram que a heterogeneidade ambiental é característica da maioria dos ecossistenas, sugerindo que trabalhar com padrão espacial nestes casos seria mais efetivo se este ambiente pudesse ser subdividido em regiões mais homogêneas. 
Camarero et al. (2000) aplicaram a função K em um estudo sobre a vegetação dos Pirineus Centrais na Espanha, a fim de descrever inicialmente seu padrão espacial e buscar evidências dos processos ecológicos mais atuantes. Suas observações permitiram destacar que perturbações freqüentes, sobretudo avalanches e ventos fortes, atuavam como elementos reguladores da vegetação.

Barot et al. (1999) concentraram-se no estudo da ecologia de uma palmeira típica das savanas úmidas da Costa do Marfim (Borassus aethiopium). Seu objetivo foi verificar quão limitada era esta espécie em razão da disponibilidade de nutrientes no solo, bem como observar a influência de competição intraespecífica sobre a população. Foi possível relacionar a escala de seu estudo com as variáveis abióticas, sobretudo solos, através da propriedade da função K de Ripley em fornecer uma análise mais minuciosa do padrão espacial em relação às escalas de distâncias.

A competição intraespecífica e a relação entre a regeneração de Cedrela lilloi, e a dinâmica de clareiras na floresta subtropical montana do noroeste da Argentina, foram os objetivos do estudo de Grau (2000). O padrão espacial observado, através da função K de Ripley, em diferentes classes de tamanho e os padrões de crescimento confirmaram, para o autor, a importância da presença de clareiras na estrutura daquela população.

Nicotra (1998) investigou o padrão espacial e a estrutura sexual de Siparuna grandiflora em uma floresta tropical da Costa Rica. O autor, utilizando-se da função K bivariada, não encontrou evidências de inibição ou segregação entre os sexos, apenas padrões gerais agregados para a população como um todo.

Anjos et al. (1998) utilizaram a função K de Ripley para avaliar o impacto do manejo sustentável do palmiteiro (Euterpe edulis) em Blumenau, Santa Catarina. Procuraram observar mudanças no padrão espacial após o corte seletivo. Em suas conclusões, os autores argumentaram que o manejo proposto não acarretaria em impactos severos para a espécie, uma vez que os padrões pré e pós-corte foram semelhantes.

Pélissier (1998) estudou o padrão espacial das árvores no sul da Índia. Diferenças de topografia e de cobertura do dossel foram apontadas como as principais 
causas dos padrões agregados observados.

Batista \& Maguire (1998) também utilizaram a função K de Ripley para investigar o padrão espacial das árvores de uma mata de tabuleiro em Linhares, no Espírito Santo, com o objetivo de modelar a estrutura espacial desta floresta, submetida a diferentes condições de manejo. 


\section{PADRÃO ESPACIAL DAS ÁRVORES DE QUA- TRO FORMAÇÕES FLORESTAIS DO ESTADO DE SÃO PAULO.}

\section{Resumo}

Padrões espaciais de árvores são influenciados principalmente por variáveis físicas, como relevo, disponibilidade de nutrientes e água, e por variáveis bióticas, como dispersão de sementes, e processos dependentes da densidade, como competição e herbivoria. As formações florestais são caracterizadas pela interação entre todos estes fatores, e estudar o padrão espacial das árvores em diferentes florestas implica em estudar a ecologia de cada comunidade. A descrição do padrão espacial em cada formação florestal e segundo classes de diâmetro foi realizada usando estatísticas descritivas apropriadas para mapas de vegetação, como a função $K$ de Ripley. O padrão agregado foi o mais comum: as árvores na Savana Florestada (Cerradão) e na Floresta Pioneira com Influência Marinha (Restinga) mostraram padrões muito semelhantes; as árvores da Floresta Ombrófila Densa Submontana mostraram níveis de agregação muito pronunciados, e as árvores da Floresta Estacional Semidecidual apresentaram certa tendência à aleatoriedade, sobretudo para distâncias maiores, embora tenha sido observado um padrão agregado para curtas distâncias. O padrão espacial por classes de diâmetro foi, em linhas gerais, agregado para as duas primeiras classes (árvores menores que $10 \mathrm{~cm}$ de diâmetro, e entre 10 e $20 \mathrm{~cm}$ ), e aleatório para as demais, evidenciando uma tendência de que árvores jovens são mais agregadas do que árvores adultas.

Palavras-chave: função K de Ripley, análises de segunda ordem, parcelas permanentes, 
floresta ombrófila densa submontana, cerradão, restinga, floresta estacional semidecidual

\section{Summary}

Tree spatial patterns are influenced mainly by physical environment, as topography, nutrients and water availability, and biotic environment, as seed dispersion and density-dependent processes, as competition and herbivory. Forest comunnities are characterized by interactions between those factors. Spatial pattern studies in diferent forest communities can support inferences about forest ecology. Description of the spatial pattern in each forest stand and the spatial pattern in diameter classes were made using reduced second order analysis, as Ripley's K function. The agreggated pattern was the most common one: the spatial patterns of trees from Forest Savanna and Restinga were very close; Dense Rain Forest trees showed strong agreggation levels, while Seasonal Semideciduous Forest trees showed tendecies towards random pattern, specially for long distances, and a clumped pattern for short distances. The spatial pattern for diameter classes was aggregated for the first two classes $(d<10 \mathrm{~cm}$ and $10 \leq d<20 \mathrm{~cm})$, and random for the other ones, showing a tendecy where small and young trees usually have more agreggated patterns than adult ones.

Key words: Ripley's K function, permanent plots, dense rain forest, forest savanna, restinga, seasonal semideciduous forest.

\subsection{Introdução}

Estudar o padrão espacial das árvores permite analisar a estrutura da comunidade em si, de processos ecológicos importantes, como competição, herbivoria e dispersão de sementes (Barot et al. 1999, Schwarz et al. 2003), e observar a influência de recursos limitantes. Variáveis abióticas, a história de perturbações, a dinâmica do dossel e a complexidade da estrutura vertical também refletem-se no padrão espacial das árvores de uma floresta (Armesto et al. 1986, Haase et al. 1997, Batista \& Maguire 
1998, Anjos et al. 1998, Coomes et al. 1999, Kuuluvainen \& Rouvinen 2000). A análise espacial de uma floresta, embora não possa identificar diretamente os processos ecológicos que atuam na comunidade, pode levar a inferências sobre quais processos são mais importantes (Kenkel 1988, Coomes et al. 1999).

A dinâmica de aberturas freqüentes no dossel está intimamente ligada com a estrutura vertical da floresta, ou seja, a composição dos seus diferentes estratos. Mudanças constantes no dossel, em razão de aberturas freqüentes de clareiras (Leemans 1991, Armesto et al. 1986, Grau 2000), e o aparecimento de condições microclimáticas distintas (Augspurger 1983) acentuam o mosaico sucessional que caractariza a maioria das florestas tropicais (Hubbell 1979).

Estudar o padrão espacial das árvores que constituem o sub-bosque e dossel, assim como as relações espaciais entre árvores adultas e jovens, ao lado de estudos abordando a escala de perturbações e a heterogeneidade ambiental (Hubbell 1979, Schwarz et al. 2003), pode auxiliar a caracterizar a dinâmica de regeneração das florestas tropicais (Grau 2000), oferecendo subsídios importantes para a compreensão da estrutura horizontal e vertical da floresta, e avaliar como os processos ecológicos de cada bioma interferem nos estágios de vida das árvores.

A estrutura da comunidade, sobretudo no que se refere à estrutura etária e ao padrão espacial, reflete os acontecimentos da história natural das populações que a compõem (Sterner et al. 1986, Haase 1995). Outros processos ecológicos, como a competição interespecífica e intraespecífica (Kenkel 1988), a herbivoria e presença de patógenos, limitação na dispersão de sementes, a disponibilidade de nutrientes, água e luz definem o sucesso no recrutamento e na colonização do sub-bosque e dossel da floresta, a densidade das populações e, por fim, o seu padrão espacial (Hubbell 1979, Batista 1994).

Algumas das teorias mais influentes em ecologia florestal envolvem a questão espacial. Entre as principais, estão as teorias de Janzen (1970), Connell (1978) e Hubbell (1979). Resumidamente, as idéias dos dois primeiros relacionam o padrão espacial das árvores com processos ecológicos atuantes ao longo do ciclo de vida de cada 
árvore. Quanto mais distante de adultos, segundo tal teoria, maiores seriam as chances de sobrevivência dos jovens. A dispersão de sementes seria, assim, questão-chave no sucesso do estabelecimento e crescimento das novas plantas, na medida que lança os propágulos a locais mais favoráveis. Tal teoria é comumente chamada de hipótese de fuga de Janzen e Connell. Hubbell (1979), por sua vez, argumenta que padrões agregados, sobretudo em função da concentração de árvores jovens, são mais comuns em florestas tropicais do que padrões aleatórios, como seria esperado segundo a hipótese de fuga. Segundo este autor, a própria caracterização ambiental da floresta pode levar à formação de manchas e grupos de árvores bem definidos.

Diante de tais questões de relevante interesse em ecologia florestal, este estudo teve como objetivos: (1) a descrição do padrão espacial de cada comunidade, ou seja, o arranjo espacial de todas as árvores em cada área deste estudo, (2) e a descrição do padrão espacial por classes de tamanho. Este estudo pretende, em linhas gerais, descrever o padrão espacial geral das árvores de quatro formações florestais do Estado de São Paulo, a saber: Floresta Ombrófila Densa Submontana, Floresta Pioneira com Influência Marinha (Restinga), Floresta Estacional Semidecidual e Savana Florestada (Cerradão).

\subsection{Material e Métodos}

Este estudo foi desenvolvido em quatro Unidades de Conservação do Estado de São Paulo, em parcelas permanentes, dentro do Projeto "Diversidade, dinâmica e conservação em florestas do Estado de São Paulo: 40 ha de parcelas permanentes", do programa Biota da FAPESP. Em cada Unidade de Conservação foi montada uma parcela permanente de 10,24 ha $(320 \times 320 \mathrm{~m})$, subdividida em 256 subparcelas contíguas de $400 \mathrm{~m}^{2}$, onde todas as árvores com circunferência na altura do peito igual ou superior a $15 \mathrm{~cm}$ foram medidas, georreferenciadas e identificadas. 


\section{Áreas de Estudo}

O cerne do projeto consiste em parcelas permanentes instaladas em quatro formações florestais importantes da região sudeste do Brasil, dentro de Unidades de Conservação, descritas a seguir.

O Parque Estadual da Ilha do Cardoso, no litoral sul do Estado de São Paulo, faz parte do Complexo Estuarino Lagunar de Iguape-Cananéia-Paranaguá. Com uma área de 22500 ha, a ilha, que é a maior do estado, constitui um dos principais remanescentes de Mata Atlântica da região. A ilha possui uma grande porção central, montanhosa, com altitudes de até $800 \mathrm{~m}$, onde predomina Floresta Ombrófila Densa Submontana, e uma faixa estreita na proção sul, onde predominam planícies de sedimentação recente, como solos do tipo podzol hidromórfico, onde predomina Formação Pioneira com Influência Marinha, conhecida por Restinga (Sampaio 2004). A leste, a Ilha do Cardoso é banhada pelo Oceano Atlântico, e a oeste é separada do continente

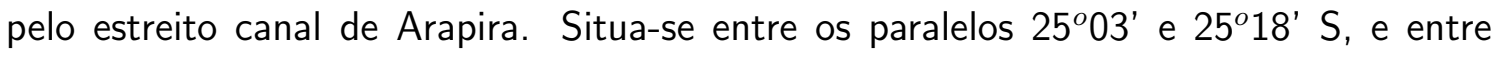
os meridianos $47^{\circ} 53^{\prime}$ e $48^{\circ} 05^{\prime} \mathrm{W}$. A temperatura varia de $19^{\circ} \mathrm{C}$ a $27^{\circ} \mathrm{C}$, e aprecipitação anual é de 1800 a $2000 \mathrm{~mm}$ (Melo 2000). O clima, assim, é classificado no sistema de Koeppen como Cfa (mesotérmico úmido sem estação seca).

O Parque Estadual de Carlos Botelho, com uma área superior a 37 mil ha, faz parte das bacias do Rio Paranapanema e Rio Ribeira de Iguape, na região sul do estado, entre as latitudes $24^{\circ} 00^{\prime}$ e $24^{\circ} 15^{\prime} \mathrm{S}$ e longitude entre $47^{\circ} 45^{\prime}$ e $48^{\circ} 10^{\prime} \mathrm{W}$. Tratase de um remanescente bem preservado de Floresta Ombrófila Densa Submontana (Dias 1993). Possui relevo extremamente acidentado, em razão da predominância de rochas graníticas. A altitude varia de 30 a 1003 m, uma vez que a Unidade de Conservação encontra-se exatamente na vertente atlântica da Serra de Paranapiacaba. A parcela permanente encontra-se em uma região com aproximadamente $150 \mathrm{~m}$ acima do nível do mar.

Segundo Negreiros et al. (1995), a temperatura média do mês mais quente é superior a $22^{\circ} \mathrm{C}$, e a temperatura do mês mais frio é menor que $18^{\circ} \mathrm{C}$. A precipitação média anual atinge aproximadamente $1600 \mathrm{~mm}$. Tais dados caracterizam o clima como 
mesotérmico úmido, do tipo Cfa na classificação de Koeppen. Elevados teores de matéria orgânica e alumínio, baixos teores de cálcio, magnésio, fósforo e potásio, e acidez elevada caracterizam os solos nesta Unidade de Conservação (Negreiros et al. 1995), classificados como latossolos vermelho-amarelos e litossolos, em grande parte da sua área (Dias 1993). A vegetação é classificada dentro dos domínios da Mata Atlântica, caracterizada pela grande precipitação e também pelo seu relevo acidentado, cobrindo originalmente desde o Rio Grande do Norte, no nordeste do Brasil, até o Rio Grande do Sul (Negreiros et al. 1995).

A Estação Ecológica de Assis, com uma área de aproximadamente 1300 $h a$, localiza-se na região oeste de São Paulo, entre as coordenadas $22^{\circ} 33^{\prime}$ e $22^{\circ} 36^{\prime}$ S, e $50^{\circ} 23^{\prime}$ e $50^{\circ} 22^{\prime} \mathrm{W}$, com altitude variando entre 520 e $590 \mathrm{~m}$, e latossolo vermelho escuro como solo predominante (Brando \& Durigan 2004). A precipitação anual fica em torno de $1400 \mathrm{~mm}$ anuais, concentrada no verão. O clima é classificado como Cwa na classificação de Koeppen. Geadas são freqüentes na região (Brando \& Durigan 2004). A Unidade de Conservação possui remanescentes de cerrado "stricu sensu" e "lato sensu", sendo esta última a fisionomia abordada nesta pesquisa.

Próximo a Assis está a Estação Ecológica dos Caetetus, com aproximadamente 21000 ha, dentro da Bacia do Médio Paranapanema (22 $41^{\prime}$ e $22^{\circ} 46^{\prime} \mathrm{S}$ e $49^{\circ} 10^{\prime}$ e 4916'W), com altitude entre 500 e $680 \mathrm{~m}$. A Estação Ecológica de Caetetus constitui uma das maiores áreas contínuas representativas de Floresta Estacional Semidecidual, com trechos em excelente estado de conservação (Franco 2002). Os solos são classificados como latossolos de textura média nos topos e podzólicos abruptos nas vertentes. A precipitação média anual é de $1400 \mathrm{~mm}$, e o clima é definido como Cwa (mesotérmico com inverno seco) na classificação de Koeppen (Franco 2002, Rocha 2003). A Floresta Estacional Semidecidual é assim chamada uma vez que grande parte de suas espécies perdem parte de suas folhas na estação seca (Ivanauskas \& Rodrigues 2000). Tal fisionomia ocupava originalmente grande parte da região sudeste do Brasil. 


\section{Função K de Ripley}

Para analisar o padrão espacial em cada área foi escolhida a Função $\mathrm{K}$ de Ripley (1977). Trata-se de uma ferramenta estatística apropriada para estudos sobre mapas de árvores, cujas principais vantagens são a possibilidade de detectar o padrão espacial em diferentes escalas simultaneamente (Getis \& Franklin 1987, Batista \& Maguire 1998) e testar a independência espacial entre grupos de árvores quaisquer (Ripley 1977, Batista 1994, Anjos et al. 1998).

São testados os desvios em relação à Completa Aleatoriedade Espacial (CAE), para a função univariada (Batista 1994), e à Completa Independência Espacial (CIE), para a função bivariada (Diggle 1983, Batista 1994, Barot et al. 1999, Coomes et al. 1999). Para este estudo, a CAE foi testada através de envelopes de confiança construídos através 1000 simulações Montecarlo, produzindo envelopes de confiança de 99,9\%. A independência entre dois conjuntos de árvores ( $\mathrm{CIE}$ ) foi analisada através de 100 "mudanças toroidais" (toroidal shifts, segundo Barot et al. 1999), produzindo envelopes de confiança de $99 \%$.

\subsection{Resultados}

A distribuição das árvores em cada parcela permanente foi analisado através da função K de Ripley. Foram levantadas 22917 árvores em Assis, 12781 em Caetetus, 10629 em Carlos Botelho e 16949 na Ilha do Cardoso.

A função K de Ripley calculada para cada formação florestal, seus respectivos envelopes de confiança, bem como os mapas das árvores em cada parcela permanente, são mostrados na figura 2. Os mapas estão em coordenadas UTM e seguem a orientação norte-sul. Nos gráficos da função K de Ripley, a linha horizontal a partir do valor $L(s)=0$ serve como referência também para os envelopes de confiança (linhas tracejadas) para os modelos de Completa Aleatoriedade Espacial (CAE) e Completa Independência Espacial (CIE).

A CAE foi rejeitada em todas as quatro áreas de estudo, embora o padrão 
espacial seja distinto entre elas (figura 2). Níveis de agregação foram observados ao longo da escala de distâncias nos quatro casos, mas em algumas áreas, sobretudo na Floresta Estacional, este comportamento foi restrito a uma escala determinada.

Quando colocadas no mesmo gráfico as curvas do padrão espacial observado nas quatro áreas (figura 2), as diferenças entre elas tornam-se ainda mais evidentes. O padrão observado na Floresta Ombrófila é bem diferente dos demais, por exemplo. Foi a única área onde o padrão agregado foi detectado para todas as distâncias. Fica evidente também, neste gráfico, a semelhança entre o padrão espacial do Cerradão e da Restinga.

Para as árvores do Cerradão, a hipótese de Completa Aleatoriedade Espacial foi rejeitada a partir de distâncias menores, até aproximadamente $120 \mathrm{~m}$. Os valores de $L(s)$ foram crescentes até $90 \mathrm{~m}$, a partir de onde a curva assume um comportamento decrescente. Isto significa que o tamanho dos agrupamentos dentro da parcela permanente variam até aproximadamente $90 \mathrm{~m}$, e que após esta escala os agrupamentos são muito menos nítidos, mas somente após a marca de $120 \mathrm{~m}$ é que pode-se dizer que não há agrupamentos observados.

Um comportamento muito semelhante foi observado para as árvores da Restinga. Embora não seja tão evidente quanto no caso do Cerradão, a curva da função $\mathrm{K}$ de Ripley também mostrou agrupamentos até $120 \mathrm{~m}$, a partir de onde a CAE foi aceita. Neste caso, porém, não é possível identificar com clareza em quais escalas de distâncias os agrupamentos são mais pronunciados, resultando em um padrão complexo de agregação.

Na Floresta Estacional a CAE foi rejeitada apenas até $45 m$ de distância. O padrão espacial predominante na Floresta Estacional foi, portanto, o padrão aleatório. Uma certa tendência em direção à regularidade foi observada, embora não tenha sido significativa, uma vez que a curva manteve-se dentro dos envelopes de confiança.

Como foi descrito anteriormente, o padrão agregado foi observado em todas as escalas na parcela permanente na Floresta Ombrófila. Não é possível diferenciar claramente em quais escalas os agrupamentos foram mais nítidos, resultando em um padrão de agregação complexo. 
a)
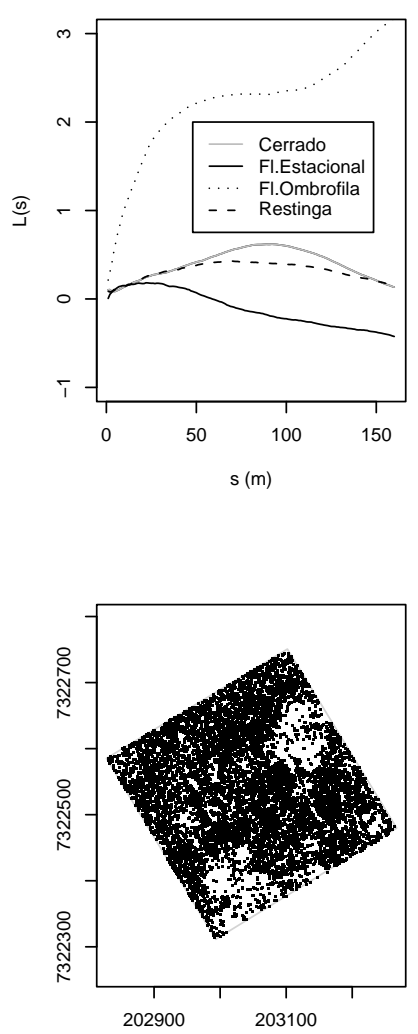

Floresta Ombrofila

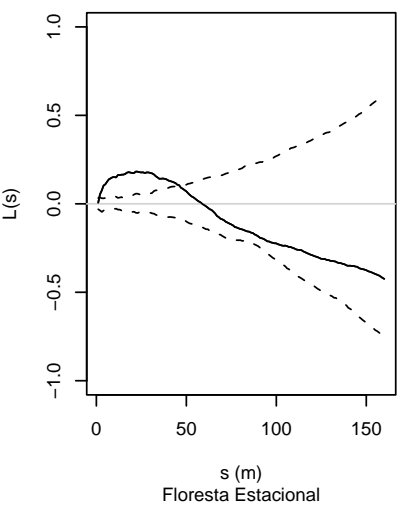

b)

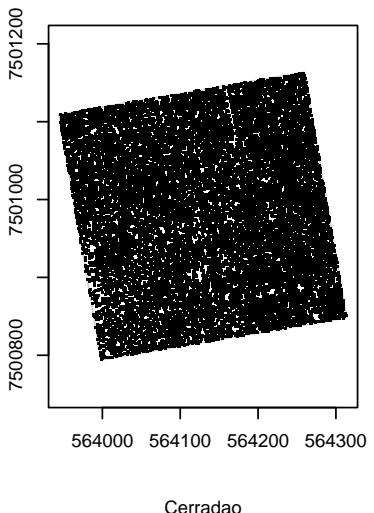

Cerradao

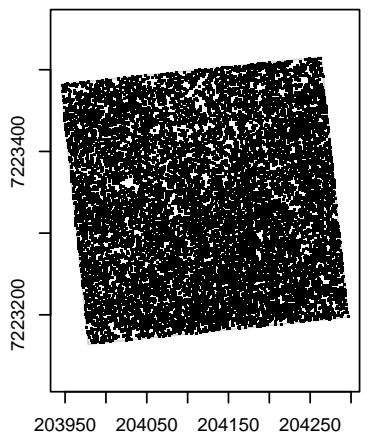

Restinga

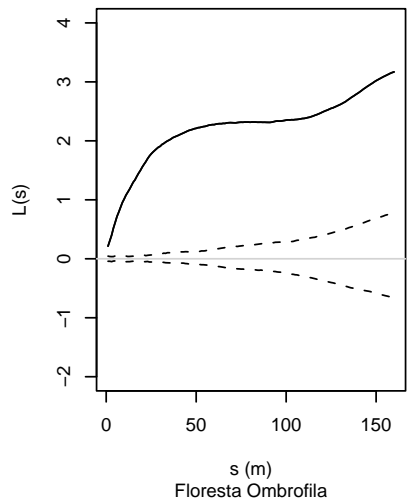

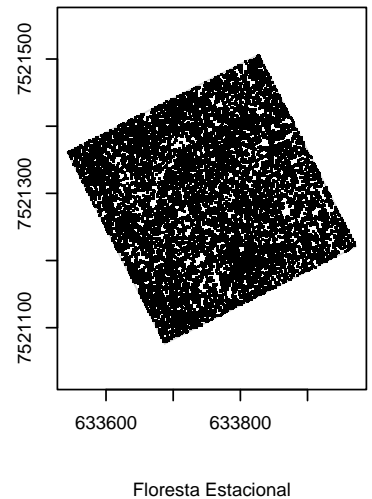

c)
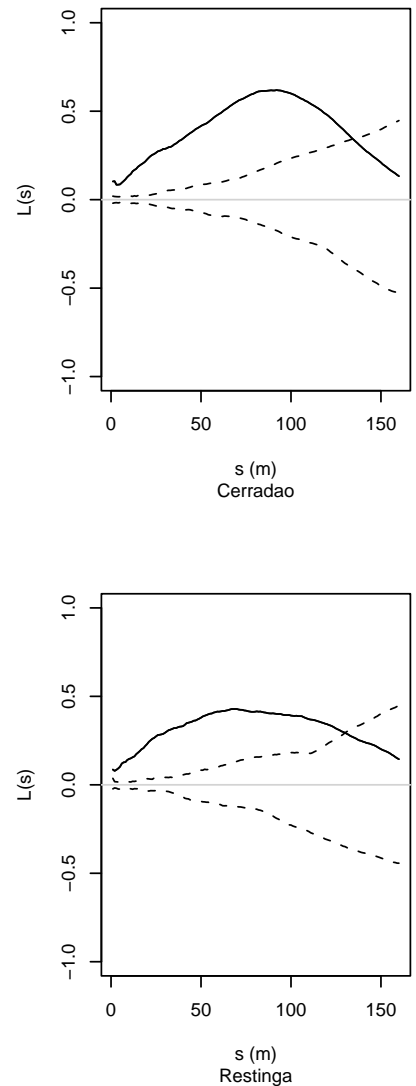

Figura 2 - Padrão espacial observado para as árvores em cada parcela permanente; a) Comparação entre o padrão das quatro áreas. b) Mapas das árvores; c) Padrão espacial observado; as linhas tracejadas indicam os envelopes de confiança de $99,9 \%$, dentro dos quais se aceita a CAE 
As árvores em cada parcela permanente foram divididas em classes de tamanho, como mostra a tabela 1. A amplitude das classes foi a mesma para as quatro áreas, de modo a facilitar a análise e a comparação entre elas. Apenas no Cerradão, em razão do número reduzido de árvores maiores que $40 \mathrm{~cm}$ em comparação com as outras áreas, é que foram definidas cinco classes, e não seis como nas demais.

Uma comparação entre a estrutura diamétrica das quatro parcelas permanentes fica mais clara através da figura 3, onde estão representadas as suas classes definidas na tabela 1 . Os quatro histogramas foram muito semelhantes, mostrando uma progressiva diminuição do número de indivíduos conforme o aumento do tamanho. Vale ressaltar que a primeira classe dos histogramas apresentados não inclui plântulas e indivíduos com menos de 1,3 $\mathrm{m}$ de altura, uma vez que o critério de inclusão foi de $C A P \geq 15 \mathrm{~cm}$.

\section{Função K univariada}

Assim, uma análise mais minuciosa do padrão espacial em cada parcela permanente foi feita tomando como base as classes de diâmetro. O padrão em cada classe foi analisado, bem como a independência espacial entre diferentes classes. Os dois itens fornecem informações ecológicas importantes, uma vez que fornecem informações sobre como evolui o padrão espacial ao longo do ciclo de vida das árvores, bem como avalia a influência do padrão das árvores adultas e senescentes com o padrão dos indivíduos mais jovens. Tais análises são descritas a seguir.

Os mapas das árvores do Cerradão, divididas segundo seu tamanho, e as análises do padrão espacial em cada classe são mostrados na figura 4.

No Cerradão, padrões agregados foram observados para as classes 1 e 2 (árvores com $d<10 \mathrm{~cm}$ e $10 \leq d<20 \mathrm{~cm}$ ), em distâncias próximas a $130 \mathrm{~m}$. Para todas as demais classes a CAE foi aceita. Na classe 5 (árvores a partir de $40 \mathrm{~cm}$ ) houve um pequeno desvio em relação à CAE em uma escala de aproximadamente $105 \mathrm{~m}$. De fato, há uma tendência de agregação para esta última classe a partir de $75 \mathrm{~m}$.

O padrão espacial observado para as árvores em cada classe de tamanho 
Tabela 1. Classes de diâmetro para as árvores em cada área de estudo

\begin{tabular}{|c|c|c|}
\hline classe & diâmetro & $\mathrm{n}^{o}$ de indivíduos \\
\hline \multicolumn{3}{|c|}{ Cerradão } \\
\hline 1 & $d<10 \mathrm{~cm}$ & 12390 \\
\hline 2 & $10 \leq d<20 \mathrm{~cm}$ & 6604 \\
\hline 3 & $20 \leq d<30 \mathrm{~cm}$ & 996 \\
\hline 4 & $30 \leq d<40 \mathrm{~cm}$ & 262 \\
\hline 5 & $d \geq 40 \mathrm{~cm}$ & 182 \\
\hline \multicolumn{3}{|c|}{ Floresta Estacional } \\
\hline 1 & $d<10 \mathrm{~cm}$ & 6063 \\
\hline 2 & $10 \leq d<20 \mathrm{~cm}$ & 3352 \\
\hline 3 & $20 \leq d<30 \mathrm{~cm}$ & 1061 \\
\hline 4 & $30 \leq d<40 \mathrm{~cm}$ & 354 \\
\hline 5 & $40 \leq d<50 \mathrm{~cm}$ & 194 \\
\hline 6 & $d \geq 50 \mathrm{~cm}$ & 259 \\
\hline \multicolumn{3}{|c|}{ Floresta Ombrófila } \\
\hline 1 & $d<10 \mathrm{~cm}$ & 4822 \\
\hline 2 & $10 \leq d<20 \mathrm{~cm}$ & 3358 \\
\hline 3 & $20 \leq d<30 \mathrm{~cm}$ & 720 \\
\hline 4 & $30 \leq d<40 \mathrm{~cm}$ & 285 \\
\hline 5 & $40 \leq d<50 \mathrm{~cm}$ & 171 \\
\hline 6 & $d \geq 50 \mathrm{~cm}$ & 231 \\
\hline \multicolumn{3}{|c|}{ Restinga } \\
\hline 1 & $d<10 \mathrm{~cm}$ & 8331 \\
\hline 2 & $10 \leq d<20 \mathrm{~cm}$ & 4111 \\
\hline 3 & $20 \leq d<30 \mathrm{~cm}$ & 1560 \\
\hline 4 & $30 \leq d<40 \mathrm{~cm}$ & 541 \\
\hline 5 & $40 \leq d<50 \mathrm{~cm}$ & 228 \\
\hline 6 & $d \geq 50 \mathrm{~cm}$ & 190 \\
\hline
\end{tabular}




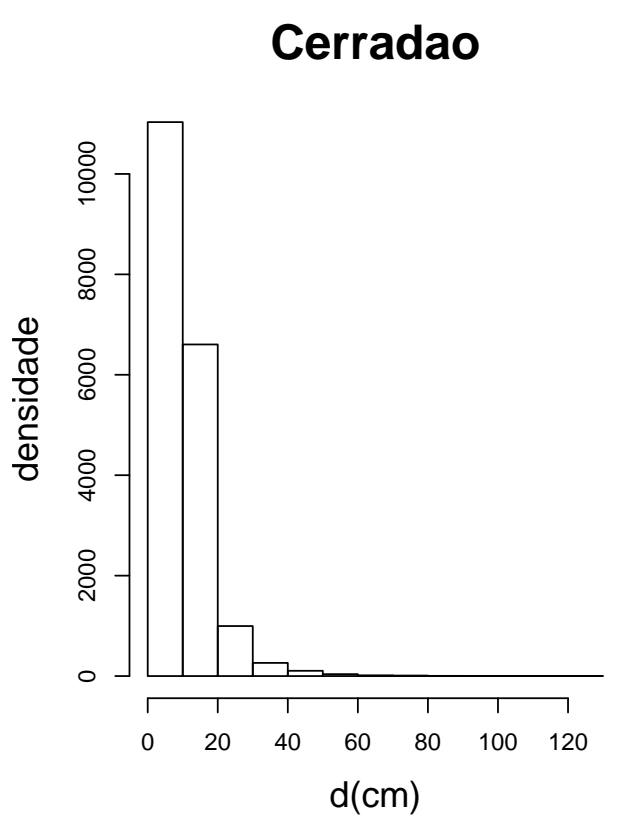

Floresta Ombrofila

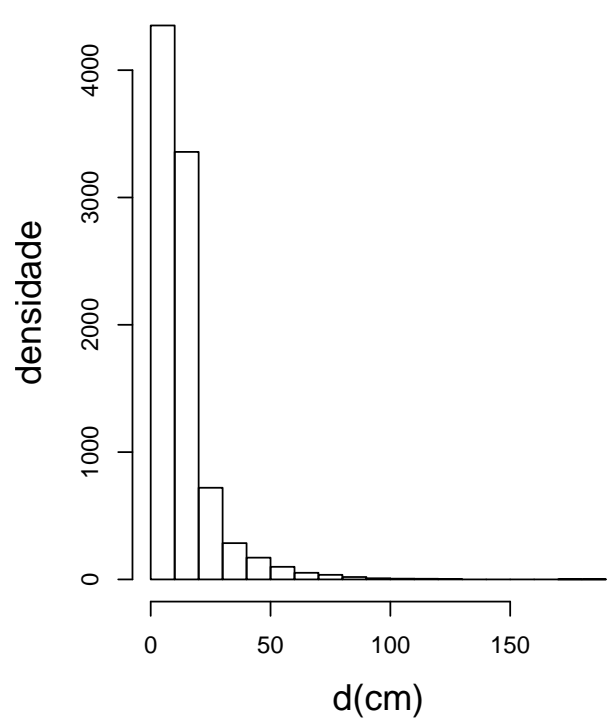

Floresta Estacional

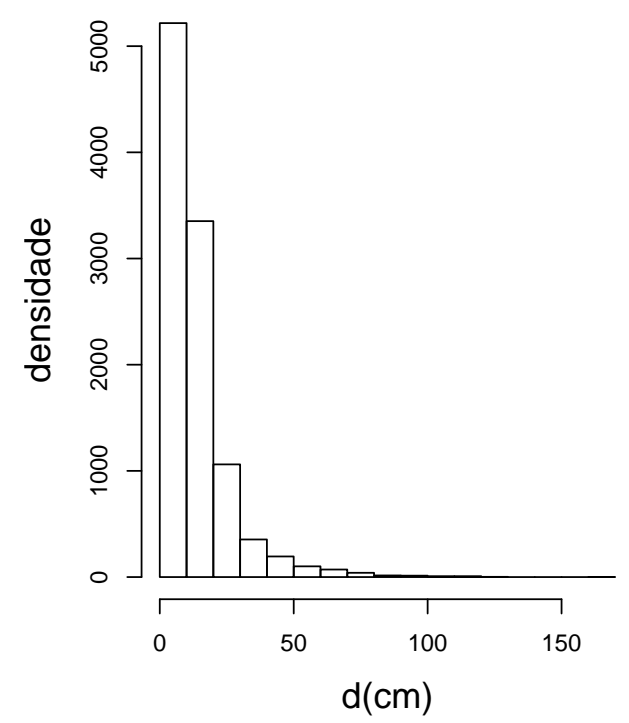

Restinga

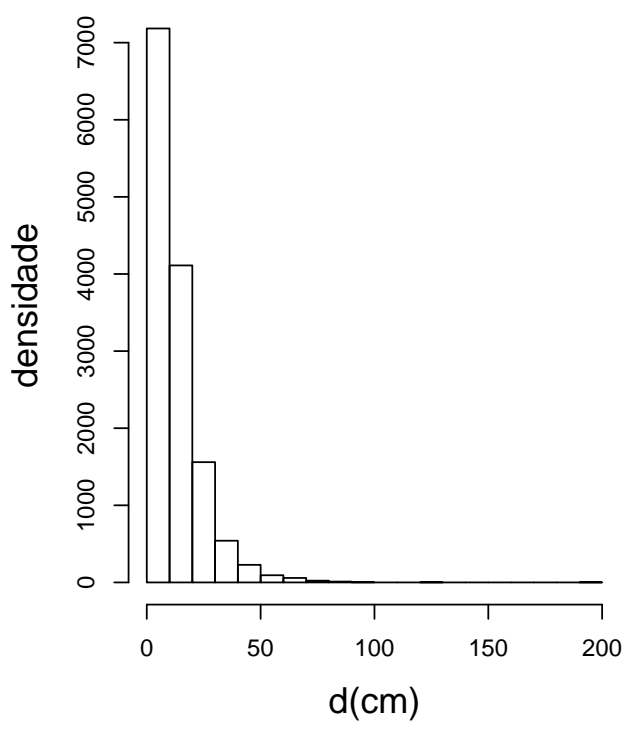

Figura 3 - Histogramas para classes de diâmetro para as árvores de cada parcela permanente 
a)

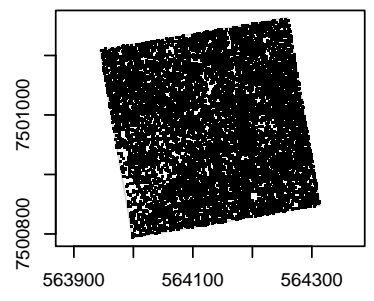

classe 1

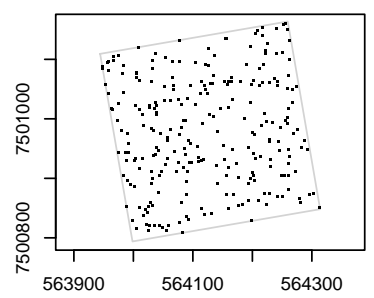

classe 4
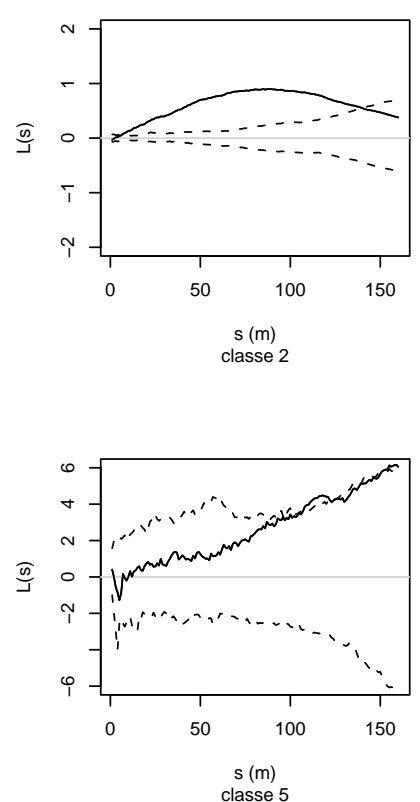

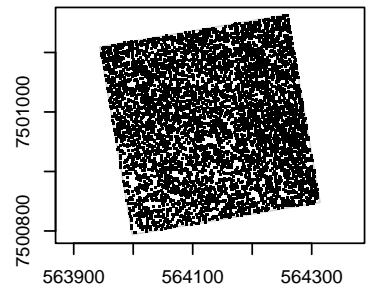

classe 2

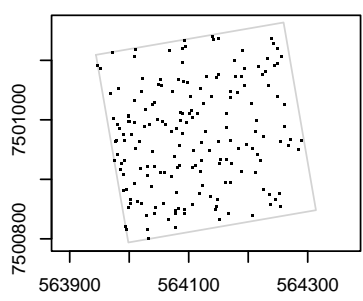

classe 5

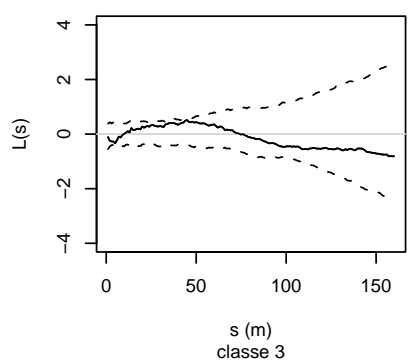

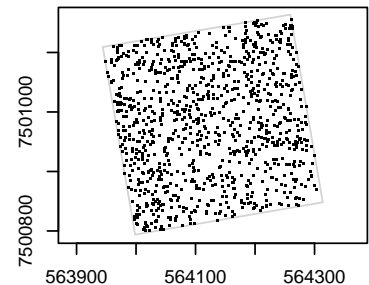

classe 3

b)
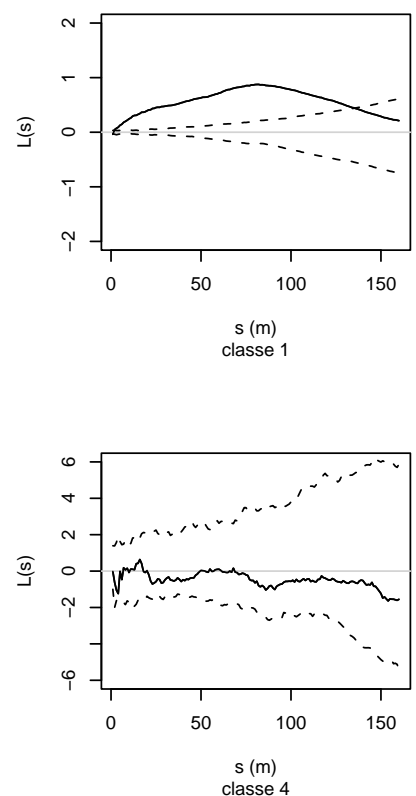

Figura 4 - Análise do padrão espacial das árvores segundo classes de diâmetro no Cerradão: a) Mapas das árvores; b) Padrão espacial observado; As linhas tracejadas indicam os envelopes de confiança de 99,9\%, dentro dos quais se aceita a $\mathrm{CAE}$ 
na Floresta Estacional é apresentado na figura 5.

O padrão espacial observado para a primeira classe (árvores com diâmetro menor que $10 \mathrm{~cm}$ ) foi agregado até $50 \mathrm{~m}$, aleatório de $50 \mathrm{~m}$ a $110 \mathrm{~m}$ e regular a partir deste ponto. Para as demais classes, o padrão predominante foi o aleatório. Apenas em duas classes houve pequenos desvios em relação à CAE: na classe 2 , até $50 \mathrm{~m}$, e na classe 6 , entre 30 e $50 \mathrm{~m}$. O formato da curva na classe 6 permite supor que as árvores maiores tenham grande tendência à agregação, embora sem significância estatística.

O mapa das árvores na Floresta Ombrófila, divididas segundo seu diâmetro

e o padrão espacial correspondente, são mostrados na figura 6. É possível identificar pelo menos duas grandes clareiras na parcela permanente, visíveis nos mapas de todas as classes. É bastante razoável supor que os efeitos destas duas áreas com poucas árvores sejam importantes para o seu padrão espacial.

Um padrão predominantemente agregado foi observado para as três primeiras classes na parcela permanente na Floresta Ombrófila, enquanto as três últimas apresentaram também padrão aleatório. O padrão da primeira classe de diâmetro foi muito semelhante ao padrão geral na área (figura 2), e a agregação foi significativa em todas as escalas para as duas primeiras classes. As três últimas classes apresentaram desvios em relação ao modelo de Completa Aleatoriedade Espacial em distâncias entre 30 e $100 \mathrm{~m}$.

O padrão espacial observado para cada classe de diâmetro na Restinga (figura 7) foi similar ao encontrado nas outras áreas de estudo: padrão agregado para as primeiras classes, e padrão aleatório para as últimas. O modelo de Completa Aleatoriedade Espacial foi rejeitado em todas as distâncias para as classes 1 e 2, e aceito para as demais, também ao longo de toda a escala de distâncias.

\section{Função K Bivariada}

Através da Função K bivariada (Ripley 1977, Batista 1994, Barot et al 1999), a independência espacial foi calculada entre todas as classes de diâmetro, em cada área de estudo. Todas as combinações possíveis foram testadas. Os resultados 
a)

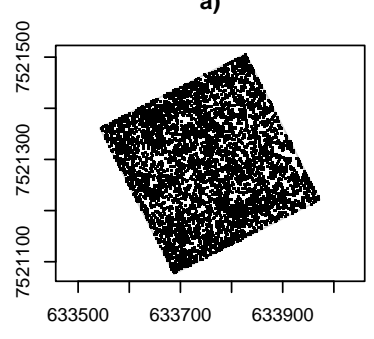

classe 1

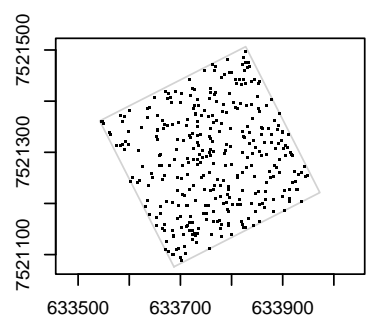

classe 4

b)
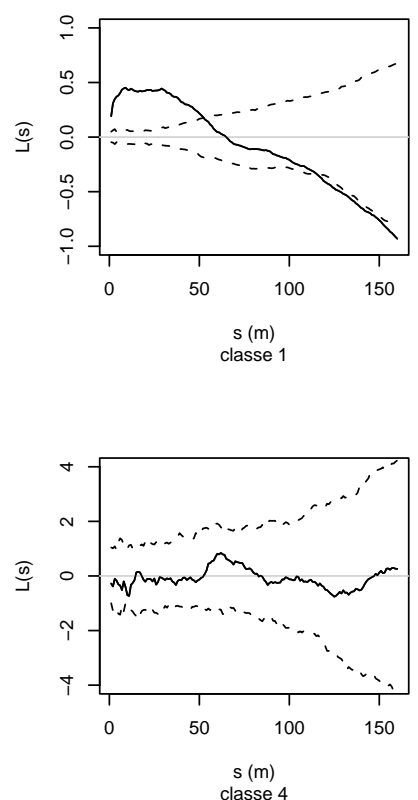

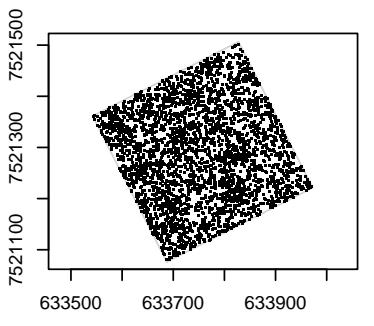

classe 2

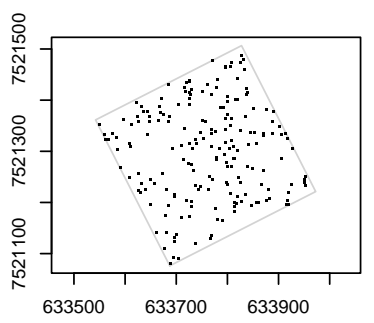

classe 5
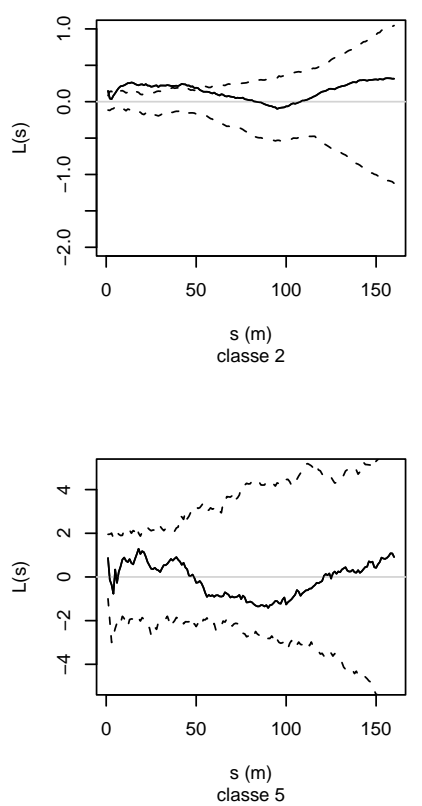

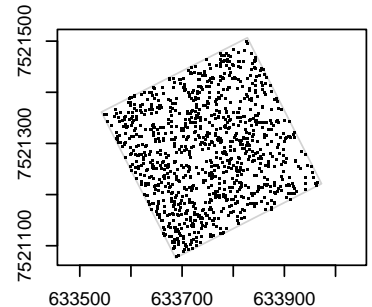

classe 3

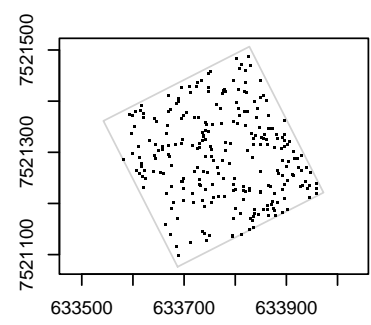

classe 6
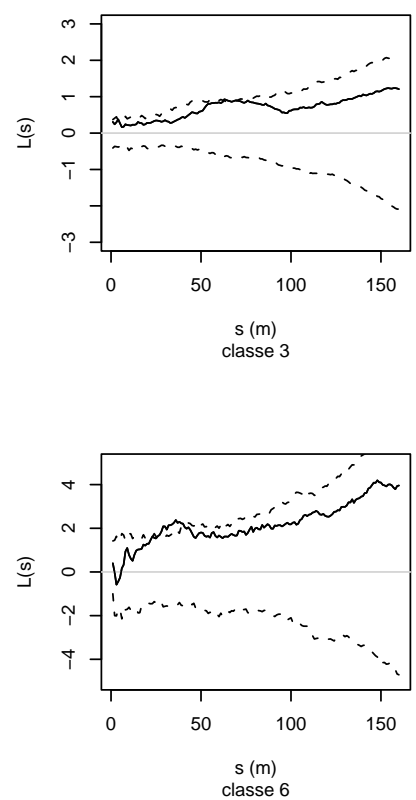

Figura 5 - Análise do padrão espacial das árvores segundo as classes de diâmetro na Floresta Estacional: a) Mapas das árvores; b) Padrão espacial observado; As linhas tracejadas indicam os envelopes de confiança de $99,9 \%$, dentro dos quais se aceita a CAE 
a)
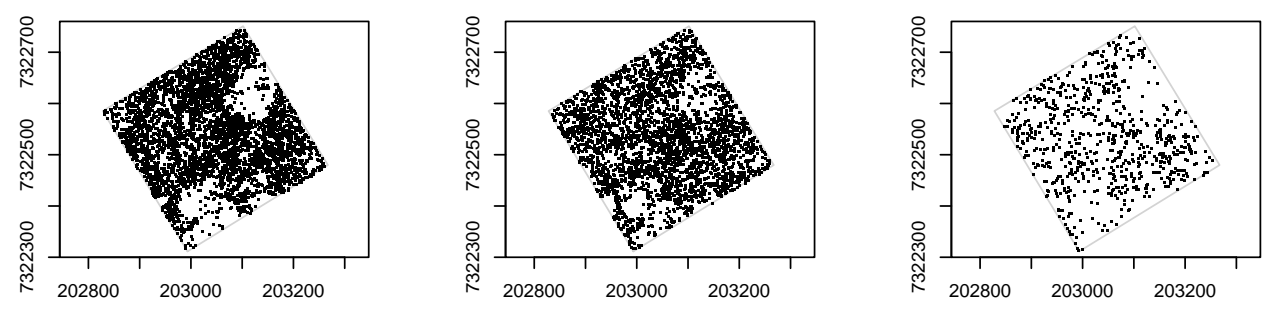

classe 1

classe 2

classe 3
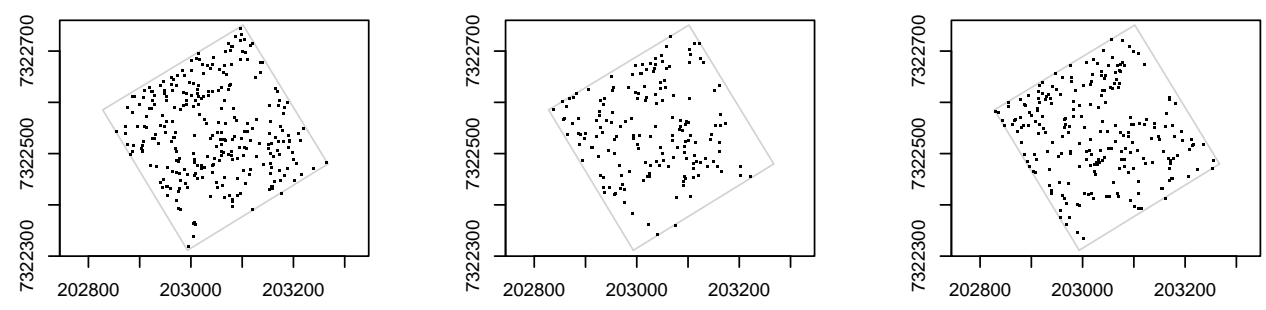

classe 4

classe 5

classe 6

b)
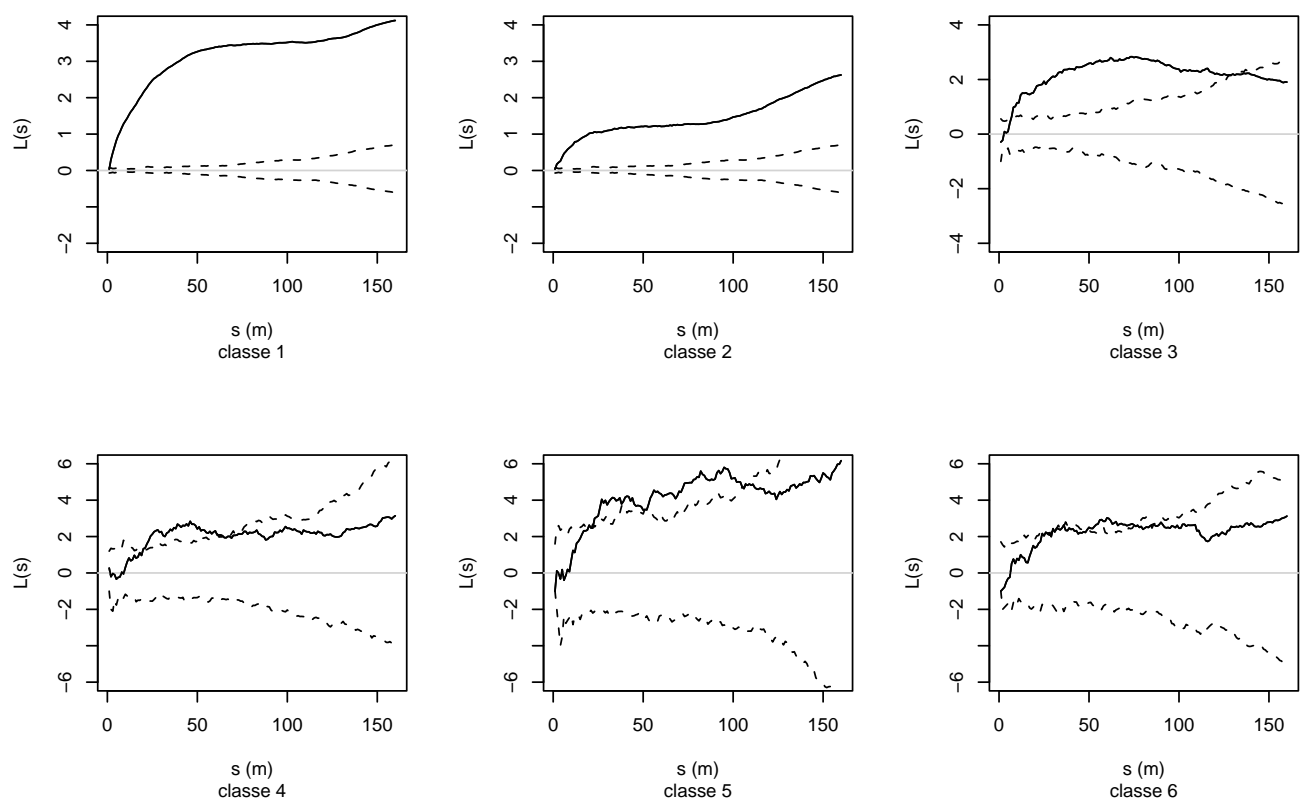

Figura 6 - Análise do padrão espacial das árvores segundo as classes de diâmetro na Floresta Ombrófila: a) Mapas das árvores; b) Padrão espacial observado; As linhas tracejadas indicam os envelopes de confiança de $99,9 \%$, dentro dos quais se aceita a CAE 
a)
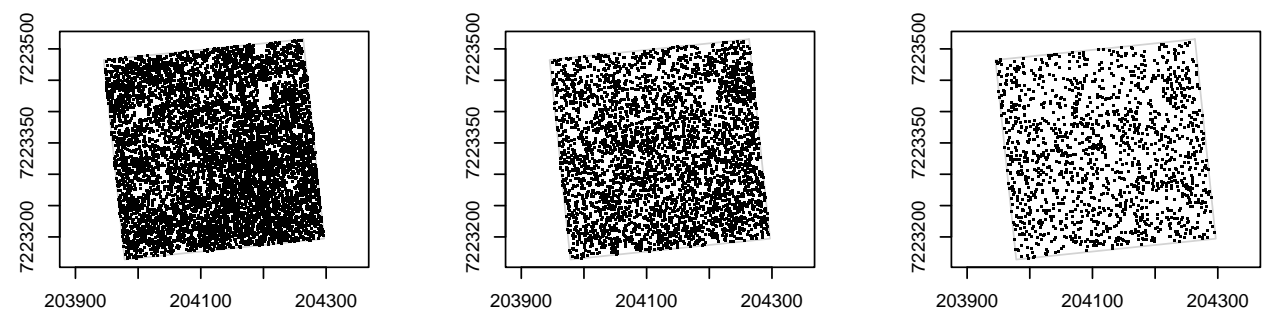

classe 1

classe 2

classe 3
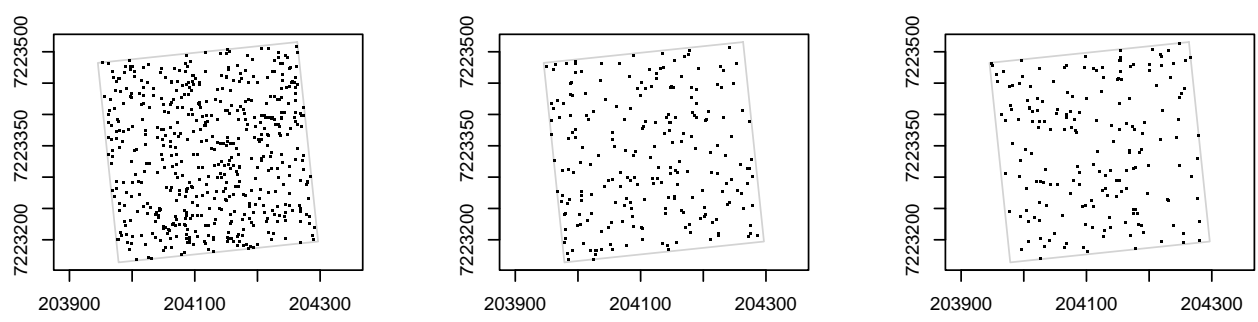

classe 4

classe 5

classe 6

b)
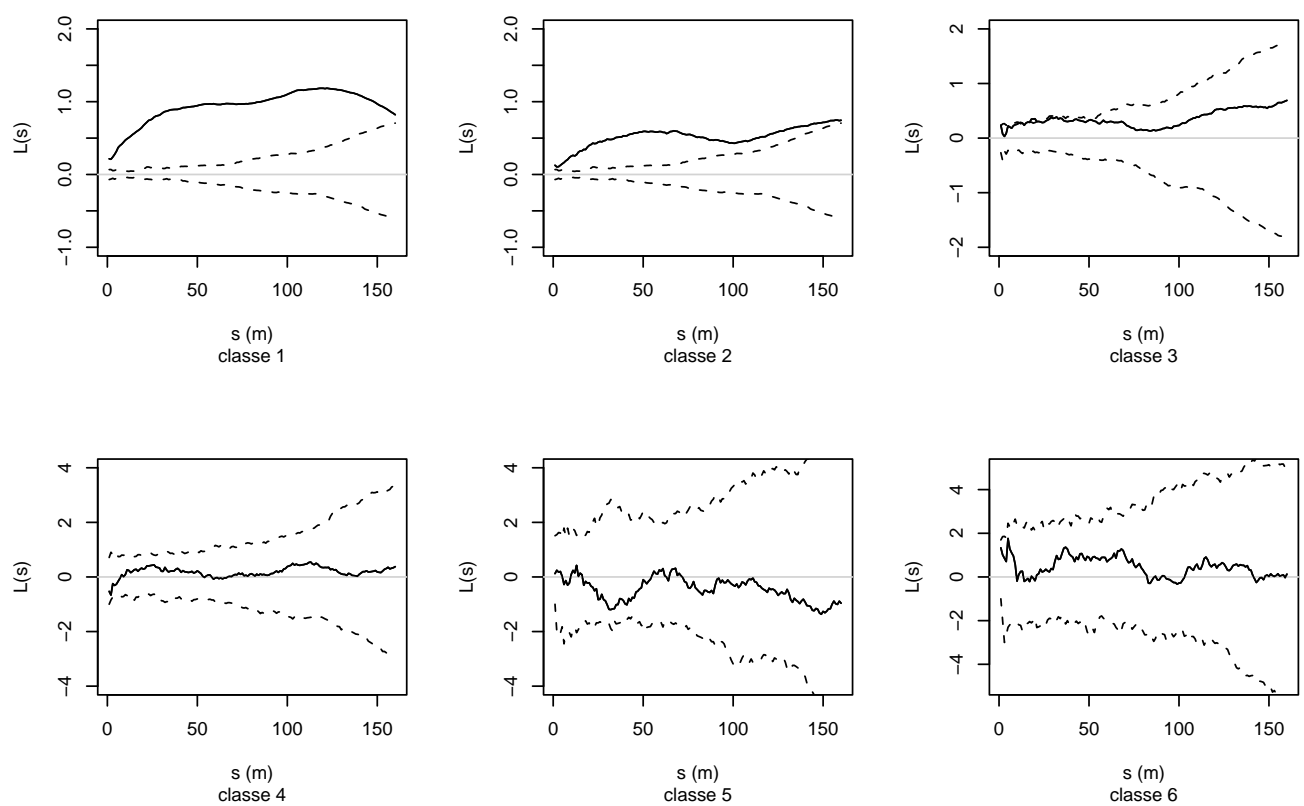

Figura 7 - Análise do padrão espacial das árvores segundo as classes de diâmetro na Restinga: a) Mapas das árvores; b) Padrão espacial observado; As linhas tracejadas indicam os envelopes de confiança de $99,9 \%$, dentro dos quais se aceita a CAE 
mostrados a seguir são aqueles onde o modelo de Completa Independência Espacial (CIE) foi rejeitado em alguma escala. Para todos os demais casos, a hipótese de CIE foi aceita.

Os resultados dos casos onde foi encontrada alguma dependência espacial, seja atração ou repulsão, são mostrados na figura 8. As classes de diâmetro seguem os códigos mostrados na tabela 1 .

No Cerradão, a função K bivariada salientou a dependência espacial entre as classes de $1(d<10 \mathrm{~cm})$ e $2(10 \leq d<20 \mathrm{~cm})$, até $110 m$ de distâncias, e entre as classes $4(30 \leq d<40 \mathrm{~cm})$ e $5(d \geq 40 \mathrm{~cm})$, a partir de $40 \mathrm{~m}$ de distâncias. Ou seja, as árvores das duas primeiras e das duas últimas classes no Cerradão mostraram certo nível de atração.

Na Floresta Estacional, a função K bivariada destacou a influência da primeira classe de diâmetro (árvores com $d<10 \mathrm{~cm}$ ), que mostraram dependência espacial (atração) com as demais classes, sobretudo com as classes 2 e 5, nas escalas de 1 a $120 \mathrm{~m}$ e de 1 a $50 \mathrm{~m}$ respectivamente. Relações de dependência espacial também foram observadas entre as classes 2 e 5,3 e 4 e entre as classes 3 e 5 , em geral em escalas de 1 a $50 \mathrm{~m}$. Assim, relações de atração espacial foram observadas tanto entre as classes mais distantes quanto para as classes intermediárias.

Na Floresta Ombrófila, a importância das duas primeiras classes, já observada no padrão espacial correspondente, é confirmada pelo fato de que ambas mostraram clara dependência espacial entre si como também com classes de diâmetro maior: a CIE foi rejeitada entre as classes 1 e 2,1 e 4,1 e 5,2 e 4 , 2 e 5 e também entre as classes 2 e 6. Na maioria das vezes o desvio em relação ao modelo, delimitado pelos envelopes de confiança, ocorreu em distâncais entre 1 e $70 \mathrm{~m}$. Destaque para a rejeição da CIE em praticamente toda a escala de distâncias entre as árvores das classes $2(10 \leq d<20 \mathrm{~cm})$ e $5(40 \leq d<50 \mathrm{~cm})$

$\mathrm{Na}$ Restinga, foram encontrados desvios em relação ao modelo de $\mathrm{CIE}$ entre as duas primeiras classes, assim como em quase todas as áreas deste estudo, e entre classes intermediárias (classes 2, 3 e 4). Em todos os casos os desvios foram 

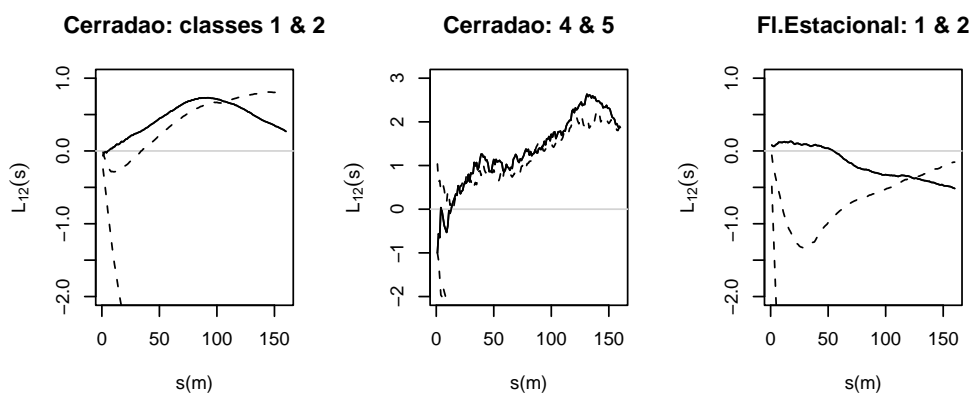

FI.Estacional: $1 \& 5$

FI.Estacional: 3 \& 4

FI.Estacional: $2 \& 5$

FI.Estacional: 3 \& 5
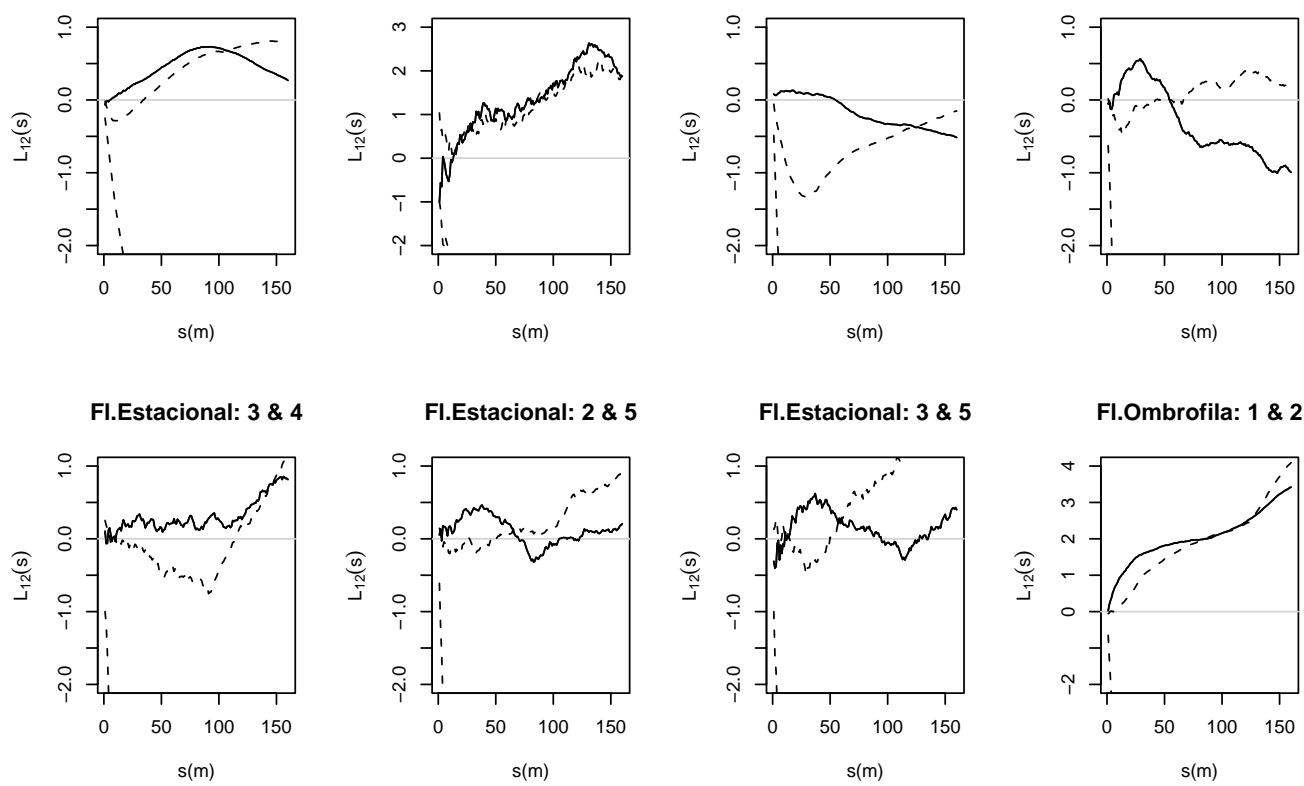

FI.Ombrofila: 1 \& 2

Fl.Ombrofila: 1 \& 4

Fl.Ombrofila: $1 \& 5$

Fl.Ombrofila: 2 \& 4
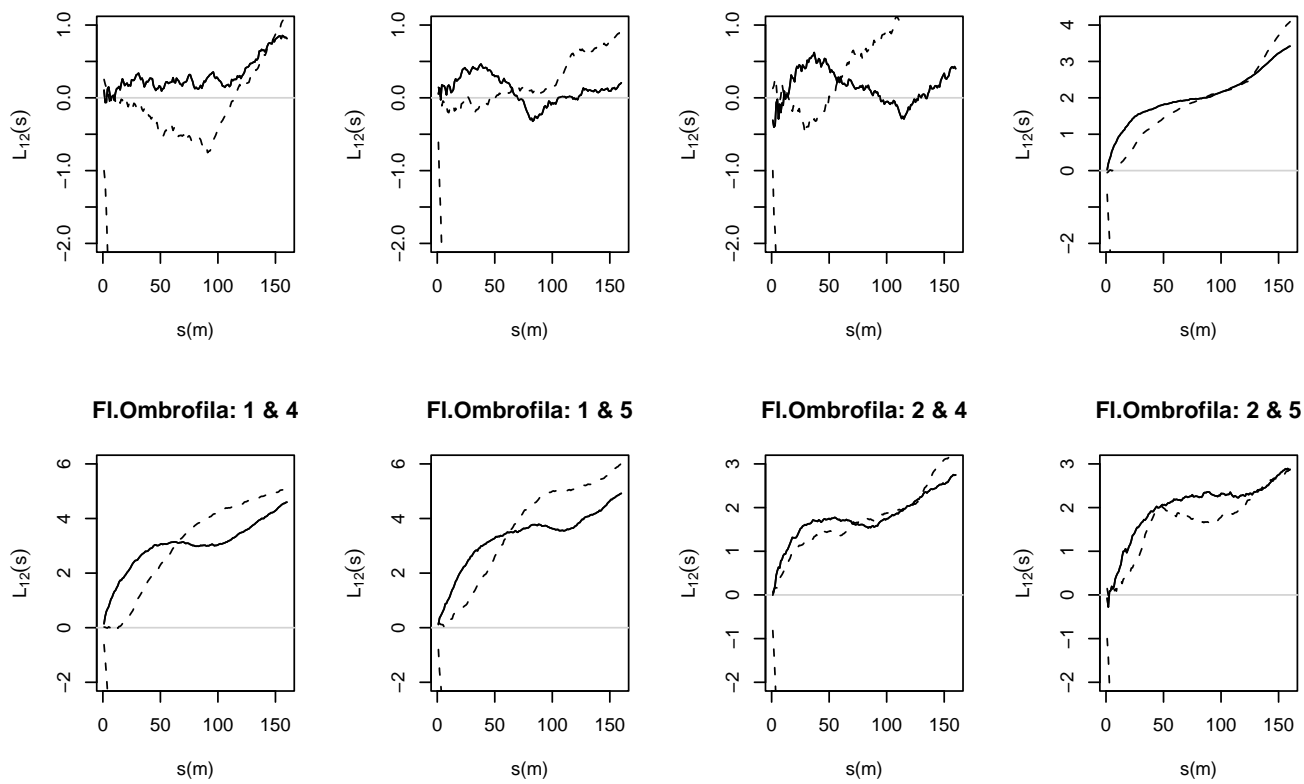

Fl.Ombrofila: $2 \& 5$

Fl.Ombrofila: 2 \& 6
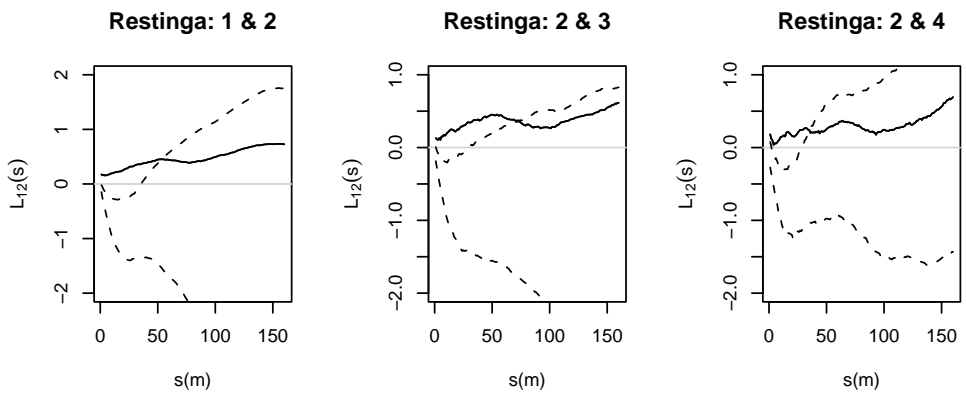

Figura 8 - Função K bivariada calculada entre as classes de tamanho nas quatro parcelas permanentes. Apenas os casos onde foi observada alguma dependência espacial são mostrados aqui. As linhas tracejadas indicam os envelopes de confiança de $99 \%$, dentro dos quais se aceita a $\mathrm{CIE}$ 
observados na escala entre 1 e $50 \mathrm{~m}$ aproximadamente.

\subsection{Discussão}

Como foi descrito anteriormente, o padrão agregado foi o predominante nas quatro áreas de estudo, mas visíveis diferenças foram notadas entre elas (figura 2). Hubbell (1979) argumenta que o padrão agregado é comum em florestas tropicais, especialmente em razão do grande de número de árvores conspecíficas na sua vizinhança. Condit et al. (1992) encontraram padrões agregados das árvores ao estudar a vegetação da Ilha de Barro Colorado, no Panamá, especialmente em função de um elevado recrutamento na vizinhança das árvores parentais. Sterner et al. (1986) encontraram padrões agregados para as quatro espécies arbóreas estudadas na Costa Rica.

Barot et al. (1999) observaram padrões agregados para as árvores de uma floresta pluvial na Costa do Marfim, especialmente árvores jovens e plântulas. Os autores apontaram diversos aspectos, sobretudo a riqueza de nutrientes no solo e a freqüência de perturbações (especialmente o fogo) na dinâmica da floresta estudada, como fatores condicionantes do padrão espacial observado.

Armesto et al. (1986), comparando o padrão espacial de florestas tropicais e temperadas, observaram que padrões agregados são mais comuns para as florestas tropicais, enquanto padrões aleatórios são comuns em florestas temperadas. Outros trabalhos científicos, entretanto, encontraram padrões agregados também em florestas temperadas (Leemans 1991, Collins \& Klahr 1991, Camarero et al. 2000, Edman \& Jonsson 2001).

Embora seja possível afirmar que as árvores nas quatro formações florestais estudadas apresentam padrão agregado, diferenças no comportamento da curva da Função K merecem maior atenção.

Para a Floresta Ombrófila, o padrão agregado foi observado ao longo de toda a escala de distâncias. O desvio em relação ao modelo de Completa Aleatoriedade Espacial (CAE) se acentua conforme as distâncias maiores. O padrão de agregação é complexo, sugerindo grupos bem definidos em inúmeras escalas distintas. 
Em contrapartida, o padrão agregado do Cerradão e da Restinga foi observado até uma mesma escala, para os dois casos ao redor de $130 \mathrm{~m}$. No Cerradão, é possível identificar um pico de agregação ao redor de $90 \mathrm{~m}$, o que sugere que a agregação é mais pronunciada nesta escala. Na Restinga, estas mesmas tendências foram observadas.

Na Floresta Estacional, o padrão agregado foi restrito a pequenas escalas, caracterizando um menor nível de agregação. Para distâncias maiores, inclusive, certa tendência à regularidade foi notada. Padrões agregados até $50 \mathrm{~m}$ podem indicar que fatores ambientais condicionantes são mais pronunciados exatamente nesta escala. Tais fatores devem atuar de modo mais forte em árvores menores que $20 \mathrm{~cm}$ de diâmetro, segundo os resultados apresentados nas análises univariada e bivariada, para as árvores da Floresta Estacional.

Condit et al. (2000) argumentam que ambientes heterogêneos correspondem a níveis elevados de agregação, enquanto áreas mais homogêneas apresentariam níveis mais baixos. Níveis de agregação são atribuídos principalmente a disponibilidade de recursos (Collins \& Klahr 1991, Grau 2000), condições microclimáticas específicas e reduzida capacidade de dispersão. De modo oposto, a intensa competição por recursos pode levar a padrões regulares (Haase et al. 1996). A disponibilidade de recursos refere-se principalmente a nutrientes e água no solo (Collins \& Klahr 1991). Condições microclimáticas favoráveis surgem principalmente em razão da estrutura do dossel da floresta, propiciando filtragem de luz e maior influência do vento (Leemans 1991, Houlle 1992), ou mesmo devido a um relevo acidentado (Condit et al. 2000, Schwarz et al. 2003).

Padrões agregados foram encontrados nas classes de diâmetro menor, e padrões aleatórios para as classes de diâmetro maior, em todas as áreas deste estudo. Observações semelhantes foram feitas em estudos de Haase et al. (1997), Busing (1998), Barot et al. (1999), Grau (2000) e Edman \& Jonsson (2001).

Para Barot et al. (1999) e Condit et al. (2000), uma das formas de se testar a hipótese de fuga de Janzen (1970) e Connell (1978) é avaliar o padrão espacial 
das árvores jovens, adultas e senescentes, e a relação de independência espacial entre as classes. Ainda segundo os autores, a passagem de um padrão agregado de jovens para um padrão aleatório de adultos ocorre principalmente em função da mortalidade dependende da densidade.

Ainda segundo Grau (2000), padrões agregados de árvores jovens em escalas menores que $15 \mathrm{~m}$ são fortes indícios da influência de clareiras produzidas pela queda de árvores do dossel na regeneração da floresta. Segundo Batista (1994) e Barot et al. (1999), plantas em diferentes estágios de vida possuem diferentes necessidades, e em função disso apresentam padrões espaciais distintos. Condições de sombreamento e filtragem de luz, assim como espaços disponíveis no dossel da floresta, são algumas características ambientais importantes para o desenvolvimento de árvores jovens.

O padrão espacial da primeira classe de diâmetro é responsável pelo padrão geral observado na Floresta Estacional: padrão agregado bem definido em escalas menores, e uma forte tendência em direção à regularidade conforme aumentam as distâcias (figura 5). Fato semelhante ocorre na Floresta Ombrófila (figura 6), onde a primeira classe de diâmetro mostrou um padrão muito semelhante ao padrão geral da floresta. Apenas no Cerradão que as árvores maiores (com diâmetro a partir de $40 \mathrm{~cm}$ ) mostraram um padrão agregado.

A função K bivariada mostrou, sobretudo na Floresta Estacional e na Floresta Ombrófila, relações de atração entre árvores de classes menores (1 e 2) com as árvores de classes maiores (5 e 6) (figura 8). Relações de atração entre as árvores menores, e também entre as árvores maiores, foram observadas no Cerradão e na Restinga. A hipótese de fuga de Janzen (1970) e Connell (1978) defende que árvores jovens e adultas tendem a repelir-se, em razão da eficiência dos métodos de dispersão de sementes e propágulos, e da mortalidade dependente da densidade.

\subsection{Conclusões}

Os resultados encontrados no presente estudo, especialmente quando foi observado que padrões agregados são comuns, são coerentes com a hipótese formulada 
por Hubbell (1979). Segundo o autor, as árvores em florestas tropicais têm padrão geral agregado, conferindo à vegetação uma fisionomia de mosaico, com grupos bem definidos, dominados por certo grupo de espécies. Este padrão é mais evidente para as árvores mais jovens, em função da limitada capacidade de dispersão. A questão da dispersão de sementes pode ser observada quando se detecta atração espacial entre estes dois grupos, o de árvores pequenas e o de árvores maiores. Segundo Janzen (1970) e Connell (1979), este padrão agregado cede espaço a um padrão agregado para árvores maiores, em razão da competição e herbivoria. Os agrupamentos de árvores jovens seriam atrativos para herbívoros e patógenos, da mesma forma que a densidade entre tais plantas jovens promoveria uma acentuada competição entre elas.

Os resultados encontrados neste trabalho salientam que diferentes processos ecológicos em cada formação florestal, bem como as características ambientais de cada Unidade de Conservação, produziram padrões espaciais distintos em cada floresta. Embora tenha sido observado que as árvores em geral tendem a agrupar-se, da mesma forma que árvores de tamanho menor tendem a formar grupos mais definidos do que árvores de tamanho maior, o tamanho dos grupos e a escala de distâncias em que tais grupos ocorreram em cada formação florestal indicam sutilezas na estrutura de cada comunidade estudada. 


\section{PADRÃO ESPACIAL DAS ESPÉCIES ARBÓREAS EM QUATRO FORMAÇÕES FLORESTAIS DO ESTADO DE SÃO PAULO}

\section{Resumo}

A descrição do padrão espacial das espécies mais abundantes em parcelas permanentes em remanescentes de quatro formações florestais do sudeste do Brasil foi realizada através da Função K de Ripley. Foram escolhidas as quatro espécies dominantes em cada parcela, bem como as espécies comuns a mais de uma formação florestal. O estudo do padrão espacial das espécies mais abundantes de uma floresta pode fornecer indícios sobre a estrutura da comunidade, bem como sobre quais os processos ecológicos e variáveis abióticas são mais importantes para a ecologia da floresta. Da mesma forma, observar o padrão espacial de uma dada espécie em diferentes ambientes pode tornar mais claro algumas características ecológicas importantes desta espécie. O padrão predominante para as espécies foi o agregado, com raras exceções. Diferentes níveis de agregação foram encontrados entre as espécies, em razão do tamanho dos grupos e da escala em que tais agrupamentos aparecem. Da mesma forma, diferenças entre o padrão espacial de duas das três espécies coincidentes entre as formações florestais indicam que seu padrão espacial é influenciado por cada ambiente diferente. O padrão espacial observado para as espécies reflete suas características ecológicas, seja em relação à tolerância à luz, deciduidade, classificação sucessional ou síndromes de dispersão de sementes. O modo com que tais espécies respondem a variáveis abióticas, como disponibilidade de nutrientes, água no solo e o relevo podem ajudar também a explicar os padrões observados. 
Palavras-chave: função K de Ripley, análises de segunda ordem, parcelas permanentes, floresta ombrófila densa, savana florestada, restinga, floresta estacional semidecidual

\section{Summary}

Description of the spatial pattern of trees from the most abundant species in permanent plots, in four tropical forest remants of southeastern Brazil, was made using Ripley's K Function. We choose the first four species in number of trees, and the common species between different forest remants. The study of most abundant species can show strong evidences about the structure of community, so as evidences about which ecological processes and abiotic factors are the most important in the ecology of each forest. Analysing the spatial pattern of a singular species in diferent environments can reveal relevant ecological features from that species. The predominant pattern was clumped, with few exceptions. Different levels of clumping were found between species, what reflects the size of clumps and its distance scales. In the same way, differences in two of three common species between differente forest remants show inherent aspects of distinct forests. The observed spatial pattern of species reveal its own ecological needs, as light tolerance, deciduousness, successional status and seed dispersion ways, and the way of responding to environmental features, as nutrients availability in soil and topography. Identifying the main aspects between many environmental features, specially in tropical forests, becames difficult.

Key words: Ripley's K function, permanent plots, dense rain forest, forest savanna, restinga, seasonal semideciduous forest.

\subsection{Introdução}

Uma espécie pode apresentar padrões espaciais diferentes segundo o ambiente onde ocorre (Armesto et al. 1986), principalmente em razão da disponibilidade de nutrientes (Collins \& Klahr 1991), da presença de potenciais competidores (Janzen 1970, 
Hubbell 1979, Sterner et al. 1986), herbívoros e patógenos (Augspurger 1983, Getis \& Franklin 1987, Barot et al. 1999, Coomes et al. 1999), do clima e da heterogeneidade deste ambiente (Getis \& Franklin 1986, Armesto et al. 1986, Condit et al. 2000).

A observação do padrão espacial de uma dada espécie em ambientes tão diferentes pode colaborar para a compreensão dos principais processos influentes em cada formação florestal. Investigar o padrão espacial das árvores é aspecto crucial para entender como as espécies usam os recursos da floresta (Condit et al. 2000).

Compreender a biodiversidade tropical é buscar nas similaridades e peculiaridades dos processos ecológicos a explicação para o grande número de espécies vegetais existentes em tais florestas (Armesto et al. 1986, Condit et al. 2000, Goreaud et al. 2002). A alta diversidade em florestas tropicais está intimamente relacionada a baixas densidades da maioria de suas espécies, refletindo diretamente no nível de agregação da vegetação. O número de árvores vizinhas da mesma espécie é, em geral, menor do que o número de árvores de outras espécies (Condit et al. 2000). Da mesma forma, é comum encontrar na floresta manchas ou grupos de árvores onde há predominância de algumas espécies, em razão de fatores ambientais, dando à floresta uma fisionomia de mosaico vegetacional (Armesto et al. 1986) e caracterizando, até mesmo intuitivamente, um padrão espacial agregado em certas escalas de distâncias.

Se uma floresta é dominada por mais de uma espécie, o padrão observado pode ser influenciado pelas interações entre as diferentes espécies (Haase et al. 1996).

Em razão da especificidade do seu nicho, espécies raras ou com nichos bem definidos podem apresentar níveis maiores de agregação que espécies comuns (Condit et al. 2000), pois podem tender a agrupar-se naquelas regiões onde as condições microclimáticas específicas Ihes favorecem. Espécies oportunistas, pioneiras ou com elevado potencial competitivo formam agrupamentos em novos habitats, definidos sobre manchas de determinados tipos de solo, áreas com incidência direta de luz ou áreas de topografia favorável (Augspurger 1984, Armesto et al. 1986, Condit et al. 2000). Espécies com reduzida capacidade de dispersão de sementes tendem a apresentar padrões espaciais com certa agregação a pequenas distâncias (Batista 1994), uma vez que locais próximos 
aos centros de dispersão terão grande possibilidade de ser ocupados por plântulas desta espécie (Condit et al. 1992, Haase et al 1997, Edman \& Jonsson 2001). A mortalidade em função da densidade (especialmente competição) contribui para alterar esse padrão, em direção a um padrão aleatório para árvores maduras, ou mesmo a um padrão regular (Janzen 1970, Kenkel 1988, Batista 1994, Haase et al. 1997) para árvores emergentes.

A relação entre árvores de mesma espécie ou de árvores de espécies diferentes também é elemento importante para seu padrão espacial (Sterner et al. 1986). Se mais de uma espécie for dominante na comunidade, o padrão espacial observado da floresta pode ser influenciado decisivamente pelas interações entre as espécies de maior densidade (Haase et al. 1997). Se a competição entre espécies é mais forte do que dentro de uma mesma população, pode se esperar uma associação negativa entre elas, com efeitos de inibição espacial (Haase et al. 1997). Se os nichos das espécies estiverem relacionados (se uma fornecer sombra à outra, por exemplo) é razoável esperar níveis de associação entre elas.

Neste artigo são descritos o padrão espacial das espécies com maior densidade em cada uma das quatro formações florestais do sudeste do Brasil abordadas neste estudo, as relações espaciais encontradas entre elas e, por fim, as similaridades e diferenças entre o padrão espacial de espécies comuns a mais de uma formação florestal serão utilizadas para iniciar uma discussão a respeito da auto-ecologia de tais espécies e da floresta.

\subsection{Material e Métodos}

Este estudo foi desenvolvido em quatro Unidades de Conservação do Estado de São Paulo, em parcelas permanentes, dentro do Projeto "Diversidade, dinâmica e conservação em florestas do Estado de São Paulo: 40 ha de parcelas permanentes", do programa Biota da FAPESP. Em cada Unidade de Conservação foi montada uma parcela permanente de 10,24 ha $(320 \times 320 \mathrm{~m})$, subdividida em 256 subparcelas contíguas de $400 \mathrm{~m}^{2}$, onde todas as árvores com circunferência na altura do peito igual ou superior a $15 \mathrm{~cm}$ foram medidas, georreferenciadas e identificadas. 


\section{Áreas de Estudo}

O cerne do projeto consiste em parcelas permanentes instaladas em quatro formações florestais importantes da região sudeste do Brasil, dentro de Unidades de Conservação, descritas a seguir.

O Parque Estadual da Ilha do Cardoso, no litoral sul do Estado de São Paulo, faz parte do Complexo Estuarino Lagunar de Iguape-Cananéia-Paranaguá. Com uma área de 22500 ha, a ilha, que é a maior do estado, constitui um dos principais remanescentes de Mata Atlântica da região. A ilha possui uma grande porção central, montanhosa, com altitudes de até $800 \mathrm{~m}$, onde predomina Floresta Ombrófila Densa Submontana, e uma faixa estreita na proção sul, onde predominam planícies de sedimentação recente, como solos do tipo podzol hidromórfico, onde predomina Formação Pioneira com Influência Marinha, conhecida por Restinga (Sampaio 2004). A leste, a Ilha do Cardoso é banhada pelo Oceano Atlântico, e a oeste é separada do continente

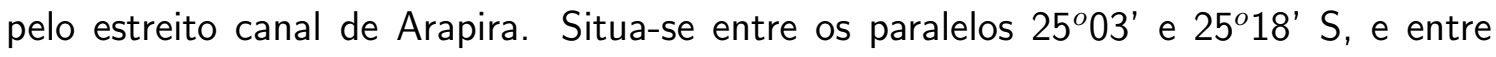
os meridianos $47^{\circ} 53^{\prime}$ e $48^{\circ} 05^{\prime} \mathrm{W}$. A temperatura varia de $19^{\circ} \mathrm{C}$ a $27^{\circ} \mathrm{C}$, e aprecipitação anual é de 1800 a $2000 \mathrm{~mm}$ (Melo 2000). O clima, assim, é classificado no sistema de Koeppen como Cfa (mesotérmico úmido sem estação seca).

O Parque Estadual de Carlos Botelho, com uma área superior a 37 mil ha, faz parte das bacias do Rio Paranapanema e Rio Ribeira de Iguape, na região sul do estado, entre as latitudes $24^{\circ} 00^{\prime}$ e $24^{\circ} 15^{\prime} \mathrm{S}$ e longitude entre $47^{\circ} 45^{\prime}$ e $48^{\circ} 10^{\prime} \mathrm{W}$. Tratase de um remanescente bem preservado de Floresta Ombrófila Densa Submontana (Dias 1993). Possui relevo extremamente acidentado, em razão da predominância de rochas graníticas. A altitude varia de 30 a 1003 m, uma vez que a Unidade de Conservação encontra-se exatamente na vertente atlântica da Serra de Paranapiacaba. A parcela permanente encontra-se em uma região com aproximadamente $150 \mathrm{~m}$ acima do nível do mar.

Segundo Negreiros et al. (1995), a temperatura média do mês mais quente é superior a $22^{\circ} \mathrm{C}$, e a temperatura do mês mais frio é menor que $18^{\circ} \mathrm{C}$. A precipitação média anual atinge aproximadamente $1600 \mathrm{~mm}$. Tais dados caracterizam o clima como 
mesotérmico úmido, do tipo Cfa na classificação de Koeppen. Elevados teores de matéria orgânica e alumínio, baixos teores de cálcio, magnésio, fósforo e potásio, e acidez elevada caracterizam os solos nesta Unidade de Conservação (Negreiros et al. 1995), classificados como latossolos vermelho-amarelos e litossolos, em grande parte da sua área (Dias 1993). A vegetação é classificada dentro dos domínios da Mata Atlântica, caracterizada pela grande precipitação e também pelo seu relevo acidentado, cobrindo originalmente desde o Rio Grande do Norte, no nordeste do Brasil, até o Rio Grande do Sul (Negreiros et al. 1995).

A Estação Ecológica de Assis, com uma área de aproximadamente 1300

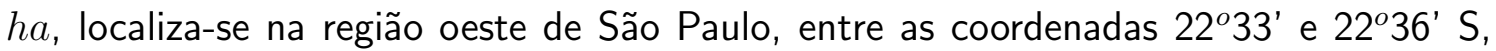
e $50^{\circ} 23^{\prime}$ e $50^{\circ} 22^{\prime} \mathrm{W}$, com altitude variando entre 520 e $590 \mathrm{~m}$, e latossolo vermelho escuro como solo predominante (Brando \& Durigan 2004). A precipitação anual fica em torno de $1400 \mathrm{~mm}$ anuais, concentrada no verão. O clima é classificado como Cwa na classificação de Koeppen. Geadas são freqüentes na região (Brando \& Durigan 2004). A Unidade de Conservação possui remanescentes de cerrado "stricu sensu" e "lato sensu", sendo esta última a fisionomia abordada nesta pesquisa.

Próximo a Assis está a Estação Ecológica dos Caetetus, com aproximada-

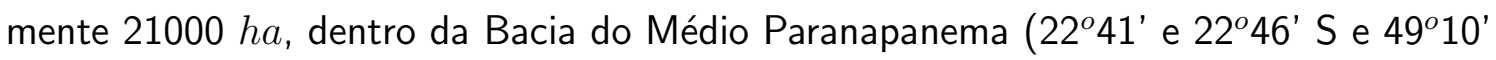
e 49 $16^{\prime} \mathrm{W}$ ), com altitude entre 500 e $680 \mathrm{~m}$. A Estação Ecológica de Caetetus constitui uma das maiores áreas contínuas representativas de Floresta Estacional Semidecidual, com trechos em excelente estado de conservação (Franco 2002). Os solos são classificados como latossolos de textura média nos topos e podzólicos abruptos nas vertentes. A precipitação média anual é de $1400 \mathrm{~mm}$, e o clima é definido como Cwa (mesotérmico com inverno seco) na classificação de Koeppen (Franco 2002, Rocha 2003). A Floresta Estacional Semidecidual é assim chamada uma vez que grande parte de suas espécies perdem parte de suas folhas na estação seca (Ivanauskas \& Rodrigues 2000). Tal fisionomia ocupava originalmente grande parte da região sudeste do Brasil. 


\section{Função K de Ripley}

Para analisar o padrão espacial em cada área foi escolhida a Função $\mathrm{K}$ de Ripley (1977). Trata-se de uma ferramenta estatística apropriada para estudos sobre mapas de árvores, cujas principais vantagens são a possibilidade de detectar o padrão espacial em diferentes escalas simultaneamente (Getis \& Franklin 1987, Batista \& Maguire 1998) e testar a independência espacial entre grupos de árvores quaisquer (Ripley 1977, Batista 1994, Anjos et al. 1998).

São testados os desvios em relação à Completa Aleatoriedade Espacial (CAE), para a função univariada (Batista 1994), e à Completa Independência Espacial (CIE), para a função bivariada (Diggle 1983, Batista 1994, Barot et al. 1999, Coomes et al. 1999). Para este estudo, a CAE foi testada através de envelopes de confiança construídos através 1000 simulações Montecarlo, produzindo envelopes de confiança de 99,9\%. A independência entre dois conjuntos de árvores ( $\mathrm{CIE}$ ) foi analisada através de 100 "mudanças toroidais" (toroidal shifts, segundo Barot et al. 1999), produzindo envelopes de confiança de $99 \%$.

\subsection{Resultados}

\section{Savana Florestada (Cerradão)}

As dez espécies de maior abundância no Cerradão são apresentadas na tabela 2. É relevante ressaltar que as quatro espécies mais abundantes, Copaifera langsdorffi, Vochysia tucanorum, Xylopia aromatica e Ocotea corymbosa, destacam-se das demais de modo que a soma dos seus indivíduos corresponde a aproximadamente $38 \%$ das árvores da parcela permanente.

A espécie com maior número de indivíduos encontrados no Cerradão foi Copaifera langsdorfii (Fabaceae). Conhecida popularmente como copaíba, esta espécie integra o dossel em florestas do Estado de São Paulo, não somente do cerrado, embora neste estudo ela tenha se sobressaído exatamente nesta formação florestal. É uma espécie decídua ou semidecídua, heliófita, secundária tardia, polinizada por abelhas, e 
cujas sementes são dispersas por pássaros, com flexibilidade de ocorrência em relação às condições de solos (Lorenzi 1992, Resende et al. 2003).

Assim como a copaíba, Vochysia tucanorum (Vochysiaceae) tem importante papel na constituição do dossel do Cerradão, em razão também da sua abundância (Barbosa et al. 1999). É uma espécie pioneira, perenifólia, heliófita e anemocórica, relativamente indiferente às condições físicas e químicas de solo, como é próprio dos solos de cerrado (Lorenzi 1992).

A espécie Ocotea corymbosa (Lauraceae) é descrita como semidecídua e heliófita, sendo comum no dossel de florestas de transição entre Cerradão e Floresta Estacional. Uma afinidade com solos bem drenados e arenosos é relatada na literatura (Lorenzi 1992).

Xylopia aromatica (Annonaceae) é uma espécie de sub-bosque, com indivíduos com altura inferior a $6 \mathrm{~m}$, de crescimento lento. Segundo Lorenzi (1992), é uma

Tabela 2. Espécies de maior densidade no Cerradão. As espécies estudadas são mostradas em negrito

\begin{tabular}{lc}
\hline Espécie & Número de indivíduos \\
\hline Copaifera langsdorffii & 3541 \\
Vochysia tucanorum & 2141 \\
Xylopia aromatica & 1602 \\
Ocotea corymbosa & 1482 \\
Machaerium acutifolium & 930 \\
Tapirira guianensis & 894 \\
Rapanea umbellata & 885 \\
Symplocos celastrinea & 738 \\
Myrcia multiflora & 662 \\
Myrcia guianensis & 649 \\
\hline
\end{tabular}


espécie pioneira e heliófita, típica do Cerrado.

Níveis de agregação foram observados para as quatro espécies, em todas as escalas, como apresentado na figura 9. Desvios em relação à Completa Aleatoriedade Espacial (CAE) foram observados para todas as populações estudadas, embora sejam evidentes diferenças entre elas.

A função K de Ripley salientou a semelhança entre o padrão espacial de Copaifera langsdorffii e Ocotea corymbosa, que pôde ser observada através do mapa das árvores (figura 9). Nos dois casos a curva da função $K$ mostrou um comportamento bem semelhante, com um pico evidente na marca de $100 m$ de distância. Esse padrão de agregação pode ser interpretado como um perfil de agrupamentos evidentes até distâncias de $100 \mathrm{~m}$, uma vez que a função, que é cumulativa, encontra cada vez mais indivíduos até esta escala. Após esta marca, a relativa ausência de indivíduos produz a queda na curva.

Comportamento semelhante também foi observado para Vochysia tucanorum, embora em outra escala e com outra intensidade. Com relação a Xylopia aromatica, embora o padrão agrupado esteja claro, o perfil de distribuição desta espécie é mais complexo. Como não há picos evidentes, e a curva da função tem um comportamento visivelmente crescente até o fim da escala adotada no estudo, não é possível identificar em quais escalas os grupos são mais evidentes. Não há registro de árvores desta espécie na região noroeste do mapa (figura 9).

\section{Floresta Estacional Semidecidual}

A tabela 3 mostra as dez espécies mais abundantes na Floresta Estacional. Metrodorea nigra concentra sozinha cerca de $33 \%$ das árvores encontradas nesta parcela permanente. A dominância dessa espécie fica ainda mais evidente quando compara-se o número de indivíduos encontrados dela com a das demais espécies selecionadas neste estudo.

A seguir são relatadas algumas informações encontradas a respeito das quatro espécies de presença mais marcante no Cerradão. 

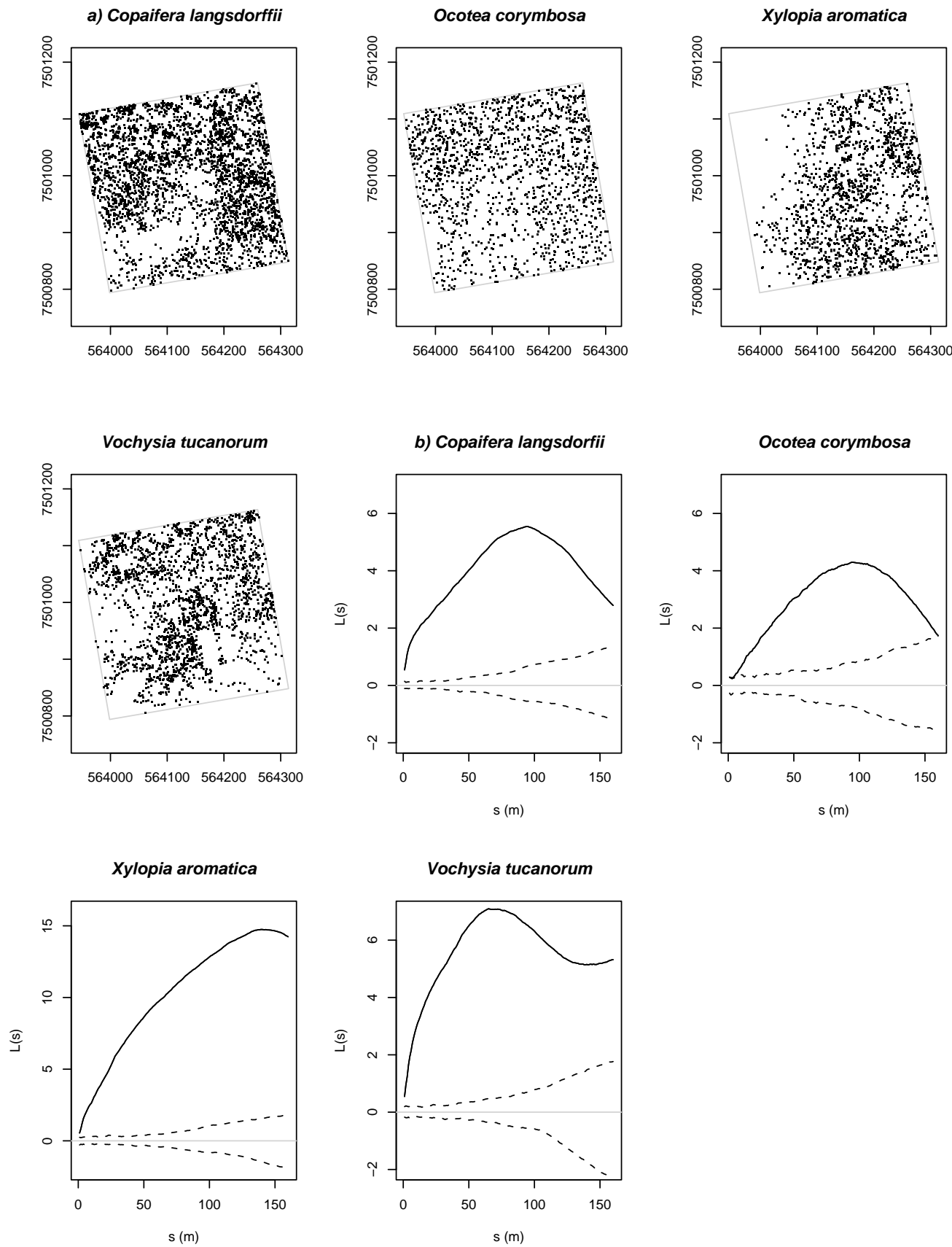

Figura 9 - Padrão espacial observado para as espécies de maior abundância no Cerradão. a) Mapas das quatro espécies; b) Padrão espacial observado para as quatro espécies; as linhas tracejadas indicam os envelopes de confiança de 99,9\%, dentro dos quais se aceita a CAE 
A espécie Metrodorea nigra (Rutaceae) é típica de sub-bosque, perenifólia, esciófita, comum na Mata Atlântica e Florestas Estacionais da Bacia do Paraná (Lorenzi 1992).

Constituinte do dossel, Trichilia claussenii (Meliaceae) busca sombra de outras árvores do dossel e tem preferência por luz difusa (Lorenzi 1992). A espécie é dispersa por pássaros e prefere solos úmidos.

A espécie Aspidosperma polyneuron (Apocynaceae) também compõe o dossel da floresta, podendo a chegar a $30 \mathrm{~m}$ de altura. É descrita como perenifólia, esciófita, e assim como Metrodorea nigra, é típica de florestas da Bacia do Paraná. Possui certa afinidade com solos profundos e férteis (Lorenzi 1992).

Entre setenta e seis espécies encontradas em um levantamento florístico na própria Estação Ecológica dos Caetetus, Ocotea indecora (Lauraceae) apresentou-se como a terceira mais abundante (Durigan et al. 2000), em relação ao Índice de Valor de

Tabela 3. Espécies de maior densidade na Floresta Estacional. As espécies estudadas são mostradas em negrito

\begin{tabular}{lc}
\hline Espécie & Número de indivíduos \\
\hline Metrodorea nigra & 4033 \\
Trichilia claussenii & 590 \\
Aspidosperma polyneuron & 587 \\
Ocotea indecora & 582 \\
Trichilia catigua & 468 \\
Centrolobium tomentosum & 374 \\
Croton floribundus & 359 \\
Balfourodendron riedelianum & 320 \\
Syagrus romanzoffiana & 305 \\
Chrysophyllum gonocarpum & 204 \\
\hline
\end{tabular}


Importância (IVI).

O padrão espacial observado para as quatro espécies em Caetetus é apresentado na figura 10 .

O padrão espacial de Metrodorea nigra foi predominantemente aleatório, sobretudo a partir de uma escala de distâncias de $50 m$ (figura 10). A espécie, portanto, apresentou tendência de agrupamento apenas em distâncias menores. Em contrapartida, o padrão de Trichilia claussenii foi agregado, sendo que a Completa Aleatoriedade Espacial foi rejeitada para todas as escalas. Para esta espécie, a função K de Ripley apontou grupos bem definidos, especialmente até a escala de $50 \mathrm{~m}$.

A CAE foi rejeitada na escala entre 5 e $75 \mathrm{~m}$ para Aspidosperma polyneuron. Nas demais escalas o padrão predominante foi o aleatório. Um comportamento ligeiramente semelhante foi observado para Ocotea indecora, entre as escalas de 5 e 110 $m$.

\section{Floresta Ombrófila Densa Submontana}

As espécies de maior densidade na Floresta Ombrófila são mostradas na tabela 4. O palmiteiro Euterpe edulis foi a espécie de maior densidade, com 2085 árvores, cerca de $20 \%$ do número total de árvores encontradas.

O palmiteiro Euterpe edulis (Arecaceae) é uma palmeira de até $20 m$ de altura, extremamente abundante na Mata Atlântica, dominante no seu sub-bosque e dossel, também em razão da sua grande produção de sementes e do elevado número de indivíduos jovens no interior da mata. É espécie perenifóila e esciófita (Lorenzi 1992), de elevado interesse comercial.

Comum na Mata Atlântica e na Restinga, Guapira opposita (Nyctaginaceae) é uma espécie perenifólia, com flexibilidade quanto às condições de luz e sombra (Lorenzi 1998), podendo chegar até a $20 m$ de altura.

Em um levantamento florístico em floresta ripária, cercado por Floresta Estacional na região sudeste do Brasil, Garcinia gardneriana (Clusiaceae) apresentou-se entre as cinqüenta espécies de maior abundância (Vilela et al. 2000). 

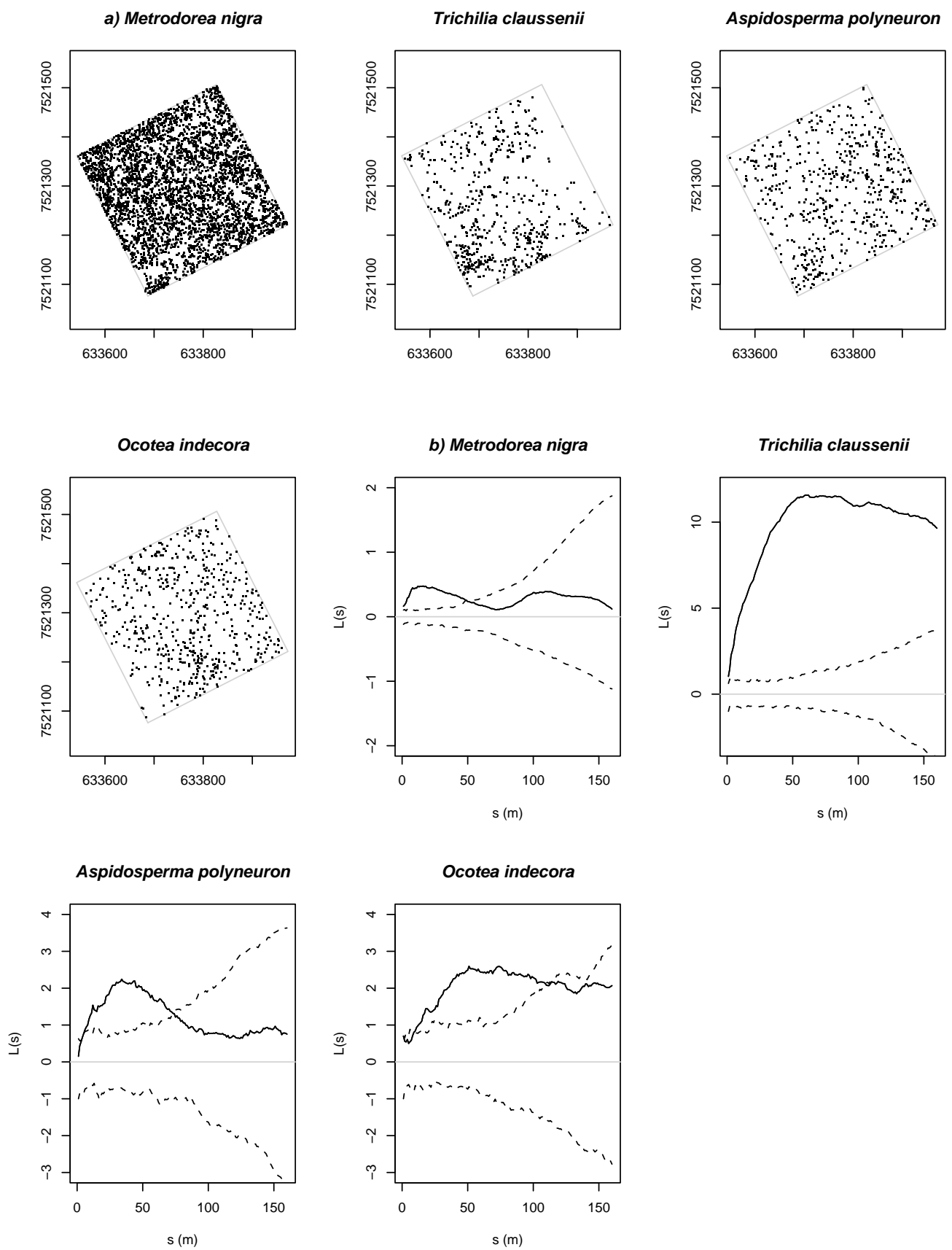

Figura 10 - Padrão espacial observado para as espécies de maior abundância na Floresta Estacional. a) Mapas das quatro espécies; b) Padrão espacial observado para as quatro espécies; as linhas tracejadas indicam os envelopes de confiança de $99,9 \%$, dentro dos quais se aceita a CAE 
Os mapas das árvores e o padrão espacial observado para as quatro espécies na Floresta Ombrófila são mostrados na figura 11.

O padrão espacial de Euterpe edulis foi agregado em todas as escalas (figura 11). Agrupamentos definidos de até $25 \mathrm{~m}$ são identificados, embora agrupamentos de diversos outros tamanhos ocorram em todas as escalas restantes.

Tanto para Bathysa merdionalis quanto para Garcinia gardneriana a Completa Aleatoriedade Espacial foi rejeitada em todas as escalas (figura 11). De fato, o padrão observado para ambas é muito semelhante, onde as curvas apresentam picos evidentes ao redor de $40 \mathrm{~m}$, para em seguida experimentar certa queda. Novamente, a interpretação destes dados sugere a presença de grupos de tamanho correspondente a esta distância. Para as demais escalas os grupos ainda existem, mas em densidade menor.

Rejeição à CAE foi observada até $90 m$ de distâncias para Guapira opposita, de modo que a partir desta escala o padrão espacial foi significativamente

Tabela 4. Espécies de maior densidade na Floresta Ombrófila. As espécies estudadas são mostradas em negrito

\begin{tabular}{lc}
\hline Espécie & Número de indivíduos \\
\hline Euterpe edulis & 2085 \\
Guapira opposita & 349 \\
Garcinia gardneriana & 248 \\
Bathysa meridionalis & 198 \\
Tetrastylidium grandiflora & 186 \\
Alsophila sternbergii & 172 \\
Rudgea jasminioides & 153 \\
Virola bicuhyba & 143 \\
Eugenia cuprea & 130 \\
Marlierea suaveolens & 120 \\
\hline
\end{tabular}



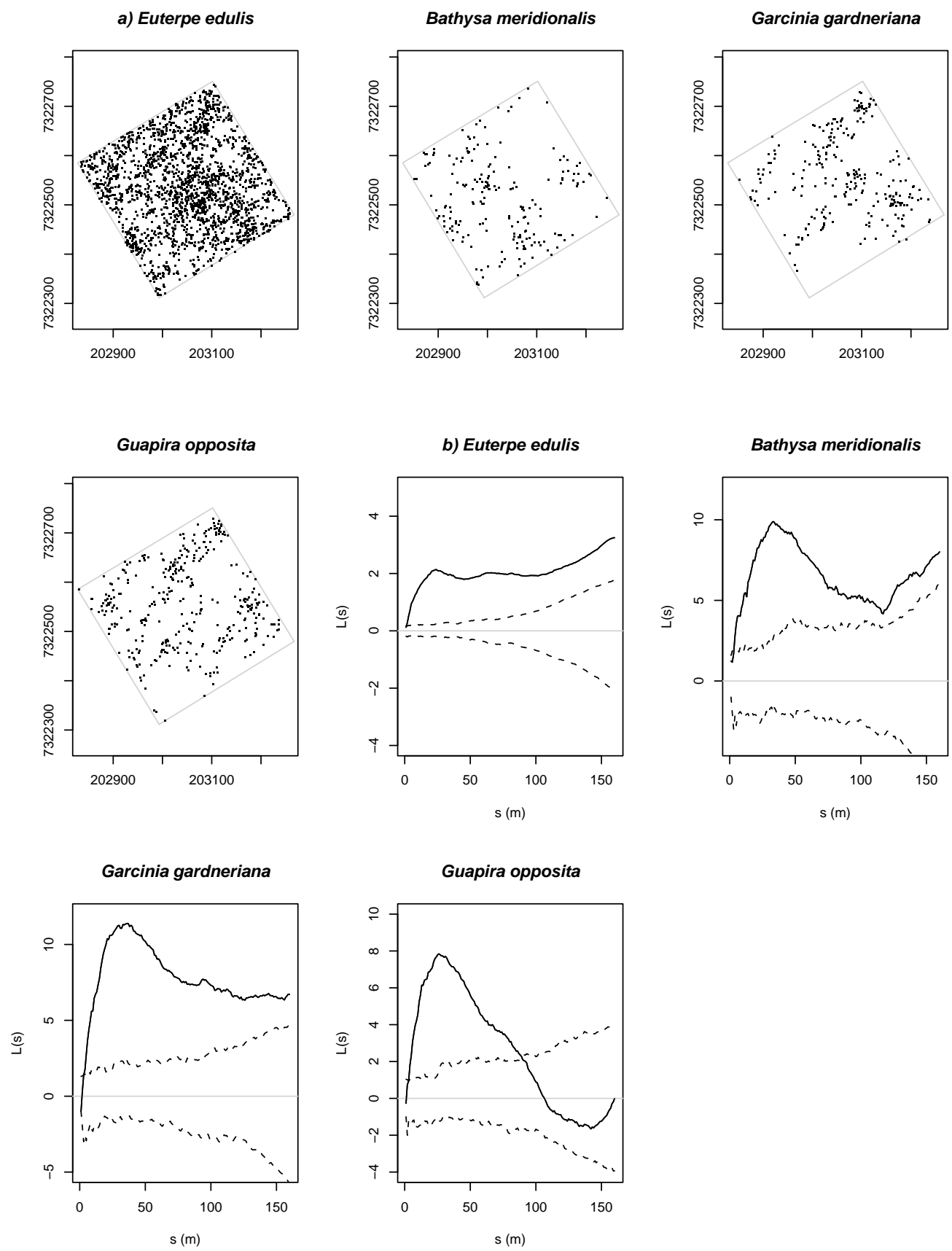

Figura 11 - Padrão espacial observado para as espécies de maior abundância na Floresta Ombrófila. a) Mapas das quatro espécies; b) Padrão espacial observado para as quatro espécies; as linhas tracejadas indicam os envelopes de confiança de $99,9 \%$, dentro dos quais se aceita a CAE 
aleatório. De fato, seu padrão assemelha-se até ao das duas espécies anteriores, não fosse pelo ajuste ao modelo de Completa Aleatoriedade Espacial em escalas maiores. A observação dos mapas destas três espécies (figura 11) já salienta esta semelhança.

\section{Floresta Pioneira com Influência Marinha (Restinga)}

A espécie de maior abundância na Floresta Ombrófila também teve o mesmo papel na Restinga: Euterpe edulis (tabela 5), com 2721 indivíduos. Novamente, a espécie dominante se sobressai quando comparado seu número de indivíduos com as espécies em seguida.

Tabela 5. Espécies de maior densidade na Restinga. As espécies estudadas são mostradas em negrito

\begin{tabular}{lc}
\hline Espécie & Número de indivíduos \\
\hline Euterpe edulis & 2721 \\
Xylopia langsdorffiana & 857 \\
Amaioua intermedia & 697 \\
Andira anthelmia & 511 \\
Ternstroemia brasiliensis & 465 \\
Ocotea pulchella & 452 \\
Pera glabrata & 407 \\
Tapirira guianensis & 403 \\
Didymopanax angustissimum & 389 \\
Myrcia racemosa & 379 \\
\hline
\end{tabular}

Uma breve descrição de Euterpe edulis foi feita anteriormente, na descrição dos resultados da Floresta Ombrófila.

A espécie Amaioua intermedia (Rubiaceae) compõe o sub-bosque das matas da Bacia do Paraná, e é descrita como perenifólia e com preferências por luz 
difusa e indiferente às condições de solo (Lorenzi 1998).

A espécie Xylopia langsdorffiana (Annonnaceae) é descrita como uma arvoreta, de até $7 \mathrm{~m}$ de altura, comum a matas da região sudeste, especialmente em São Paulo e no Rio de Janeiro (Maas et al. 2001).

Em um levantamento florístico realizado em um remanescente de Cerrado no sudeste do Brasil, em três fisionomias distintas (campo cerrado, cerado sensu strictu e cerradão), Andira anthelmia (Fabaceae) apareceu entre as principais espécies da família

encontradas (Batalha \& Mantovani 2001). É, assim, uma espécie de ampla distribuição, encontrada em diversas formações florestais, presente no presente estudo em grande densidade na Restinga.

O padrão espacial para as quatro espécies de destaque na Ilha do Cardoso é descrito na figura 12 , a seguir.

A Completa Aleatoriedade Espacial foi rejeitada em todas as escalas para Euterpe edulis, Amaioua intermedia e Xylopia langsdorffiana (figura 12). A observação do mapa destas duas últimas espécies mostra um trecho dentro da parcela permanente onde ambas não ocorrem (uma faixa na direção oeste-nordeste na porção central), salientando a semelhança entre o padrão de ambas.

Padrão agregado entre 10 e $120 m$ de distâncias foi observado para Andira anthelmia. Para as demais escalas o padrão observado foi coerente com o modelo de CAE.

\section{Dependência espacial entre as populações (Função K Bivariada)}

A Função K Bivariada (Ripley 1977, Batista 1994, Barot et al 1999) foi calculada em todas as combinações possíveis entre as quatro espécies mais abundantes em cada formação florestal estudada aqui. Na maioria dos casos não foi observado qualquer dependência espacial. Os gráficos da Função $\mathrm{K}$ bivariada para estes casos não são mostrados neste artigo. Os casos onde desvios significativos em relação à Completa Independência Espacial são mostrados na figura 13.

Conforme relatado anteriormente, foi observada grande semelhança entre o 
a) Euterpe edulis

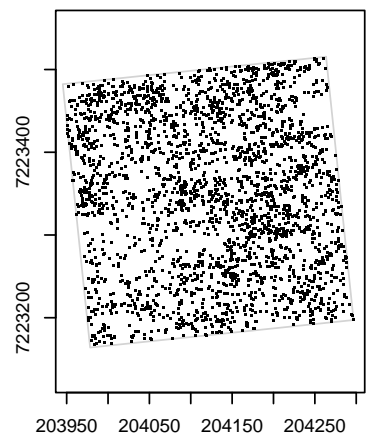

Xylopia langsdorffiana

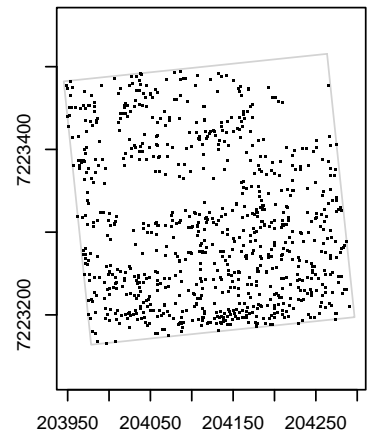

Amaioua intermedia

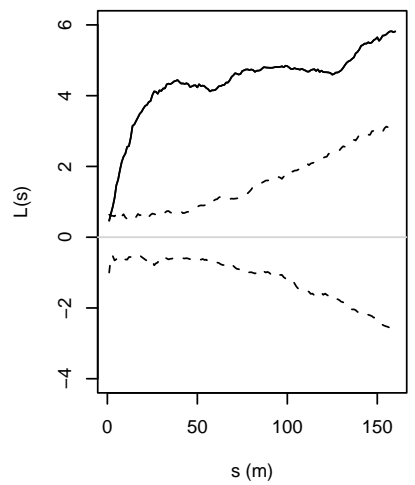

Andira anthelmia

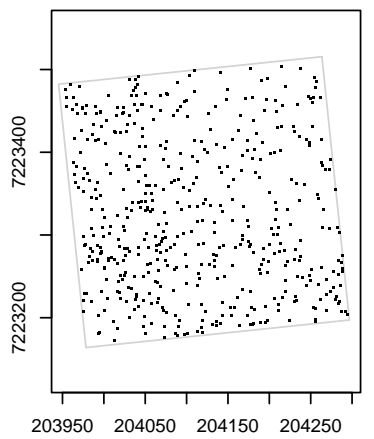

b) Euterpe edulis

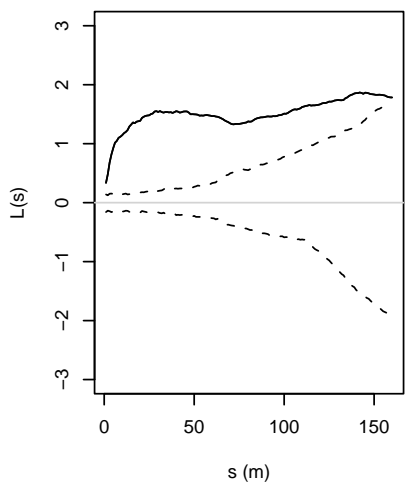

Xylopia langsdorffiana

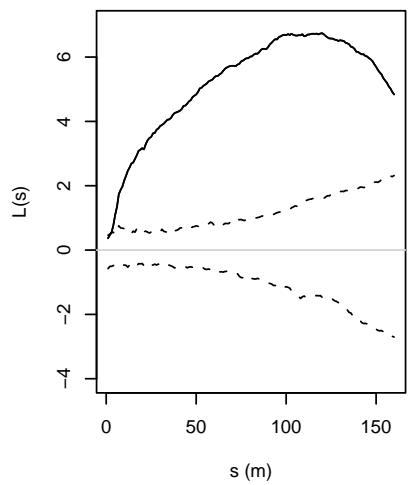

Amaioua intermedia

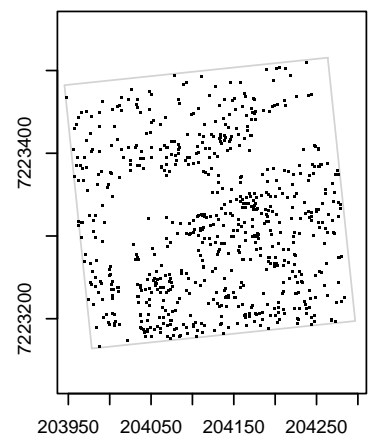

Andira anthelmia

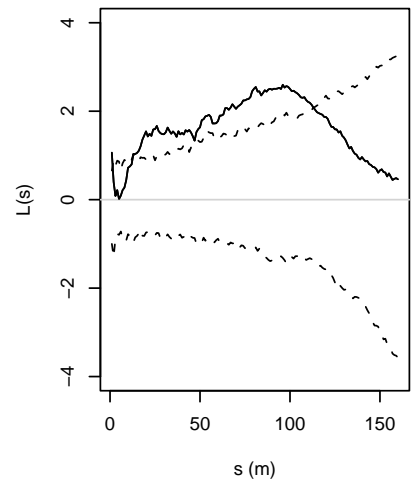

Figura 12 - Padrão espacial observado para as espécies de maior abundância na Restinga. a) Mapas das quatro espécies; b) Padrão espacial observado para as quatro espécies; as linhas tracejadas indicam os envelopes de confiança de 99,9\%, dentro dos quais se aceita a CAE 

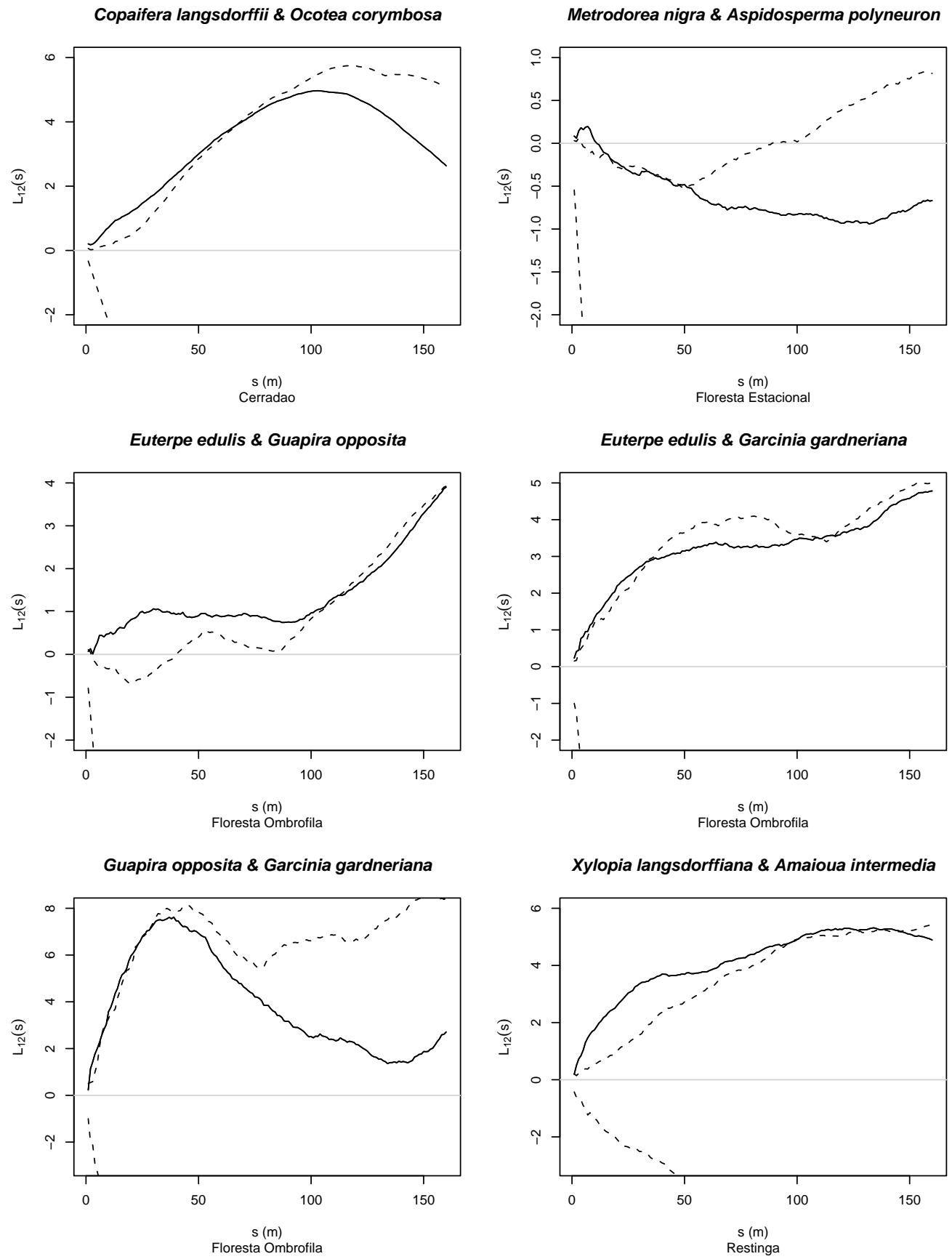

Figura 13 - Função K bivariada calculada para as espécies estudadas nas quatro parcelas permanentes. São apresentados apenas os casos onde houve dependência espacial 
padrão espacial observado no Cerradão para Copaifera langsdorffii e Ocotea corymbosa. A função $\mathrm{K}$ bivariada mostrou que ocorre certa atração entre as árvores destas duas espécies até uma escala de $60 \mathrm{~m}$.

Na Floresta Estacional, uma tímida atração foi observada entre Metrodorea nigra e Aspidosperma polyneuron até uma escala de $25 \mathrm{~m}$ de distâncias. De fato, a função K bivariada não apresentou, para as demais escalas, qualquer desvio em relação ao modelo de Completa Independência Espacial.

Na Floresta Ombrófila, ficou evidente que Euterpe edulis, Garcinia gardneriana e Guapira opposita possuem entre si certo grau de atração. Sinais claros de dependência espacial foram observados entre Euterpe edulis e Guapira opposita até 120 $m$ de distâncias.

Para a função K bivariada entre Euterpe edulis e Garcinia gardneriana foram observados desvios na escala até $45 \mathrm{~m}$ e próximo a $110 \mathrm{~m}$. Entre Guapira opposita e Garcinia gardneriana a atração foi observada até $30 \mathrm{~m}$. Para as demais distâncias foi aceita a Completa Independência Espacial.

Na Restinga, níveis claros de atração espacial entre Xylopia langsdorffiana e Amaioua intermedia foram encontrados em praticamente toda a escala de distâncias.

\section{Espécies comuns entre as formações florestais}

O palmiteiro Euterpe edulis foi a espécie mais abundante tanto na parcela permanente de Floresta Ombrófila quanto na parcela permanente da Restinga, com 2085 e 2721 árvores respectivamente. A espécie Syagrus romanzoffiana apareceu na lista das espécies mais abundantes no Cerradão (265 árvores) e na Floresta Estacional (305 árvores). De fato, em razão da proximidade geográfica entre as áreas, bem como de sua similaridade florística, era esperado que houvessem espécies em comum entre a Floresta Ombrófila e a Restinga (vale lembrar que boa parte da llha do Cardoso é coberta por Floresta Ombrófila, ainda que tenha sido a Restinga a formação florestal estudada nesta Unidade de Conservação), e entre o Cerradão e a Floresta Estacional.

A espécie Tapirira guianensis apareceu na Restinga (403 árvores) e no 
Cerradão (894 árvores). Em razão da sua densidade em cada área, e também de algumas características ecológicas relevantes entre os biomas em que ocorre, a espécie foi incluída nas análises deste artigo.

Outras espécies também marcaram presença em mais de uma formação florestal, como Garcinia gardneriana e Jacaranda puberula (presentes na Restinga e na Floresta Ombrófila), e Rapanea umbellata e Syagrus romanzoffiana (presentes na Restinga e no Cerradão). Entretanto, a diferença de abundância destas espécies nas áreas (Syagrus romanzoffiana teve 15 indivíduos na Restinga, e 265 no Cerradão) inviabiliza análises mais criteriosas. Com menos de 50 pontos aproximadamente no mapa, a Função $\mathrm{K}$ de Ripley perde definição, apresentando muita oscilação da sua curva em distâncias muito próximas. Desse modo, apenas as três espécies citadas acima foram incluídas neste estudo.

Os mapas das espécies e a função $\mathrm{K}$ de Ripley para cada uma delas, em cada área de ocorrência comum, são mostrados na figura 14.

O padrão espacial de Euterpe edulis foi bem semelhante entre a Floresta Ombrófila e a Restinga (figura 14). Nos dois casos rejeitou-se a Completa Aleatoriedade Espacial em todas as escalas.

Para Syagrus romanzoffiana (Arecaceae) o padrão foi ligeiramente diferente nas suas duas áreas de ocorrência. Na Floresta Estacional, o padrão espacial foi significativamente agregado em uma escala de 25 a $75 \mathrm{~m}$. No Cerradão, a espécie apresentou padrão aleatório para todas as escalas. Segundo Lorenzi (1992), a espécie é pioneira, típica do dossel de Florestas Estacionais e Cerradão. É uma planta perenifólia e heliófita, dispersa por animais, especialmente roedores.

A espécie Tapirira guianensis apresentou padrão agregado para todas as escalas tanto no Cerradão quanto na Restinga. Entretanto, o comportamento das curvas foi bem distinto. A função $K$ de Ripley para a espécie em Assis apresentou um pico de agregação ao redor de $100 \mathrm{~m}$, enquanto a função $\mathrm{K}$ estabilizou-se após poucos metros na Restinga, praticamente acompanhando horizontalmente o envelope de confiança da CAE. O padrão espacial da espécie no Cerradão é complexo, com grupos definidos em diversas 

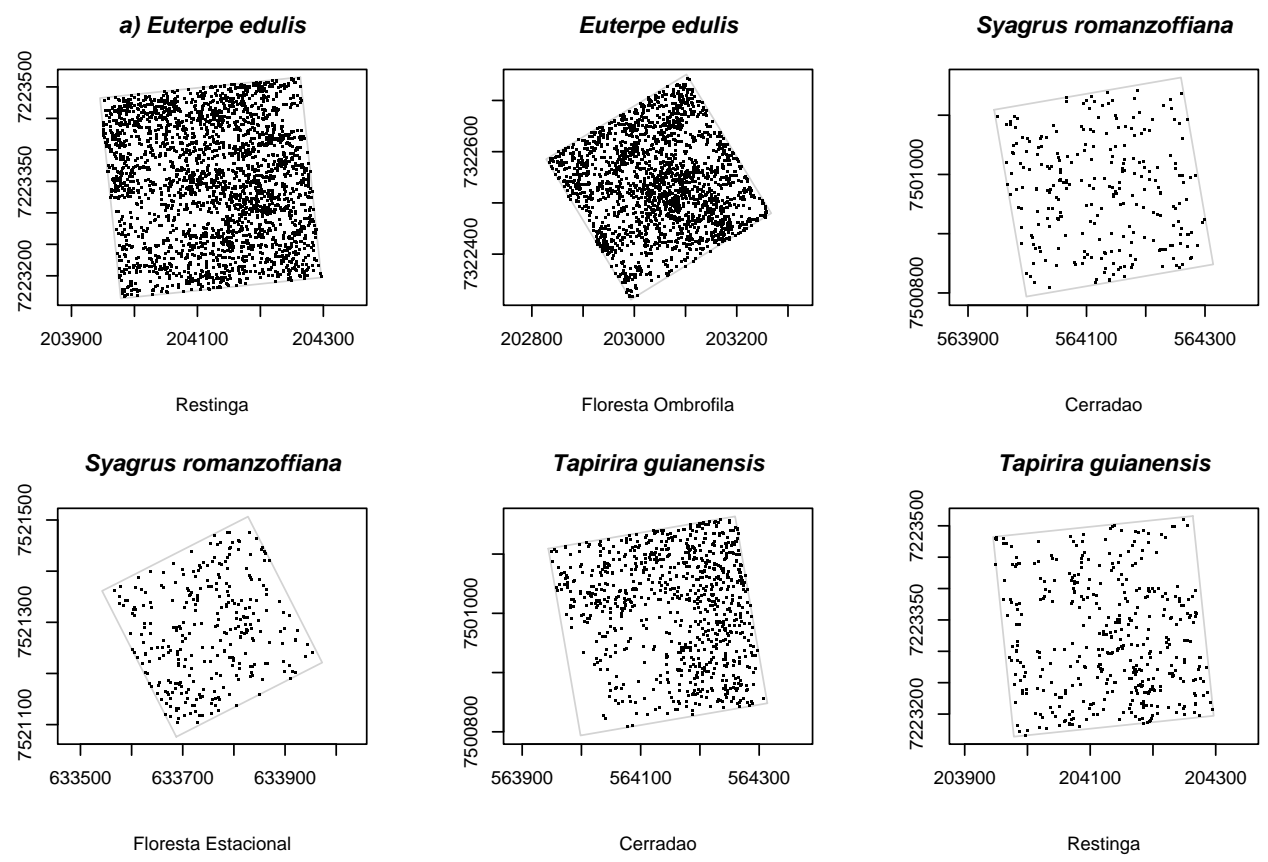

b) Euterpe edulis

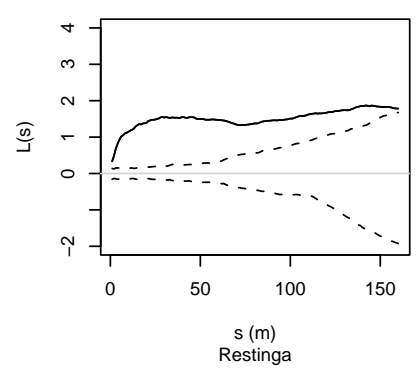

Euterpe edulis

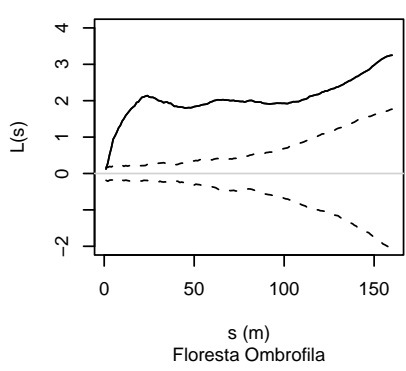

Syagrus romanzoffiana

Syagrus romanzoffiana
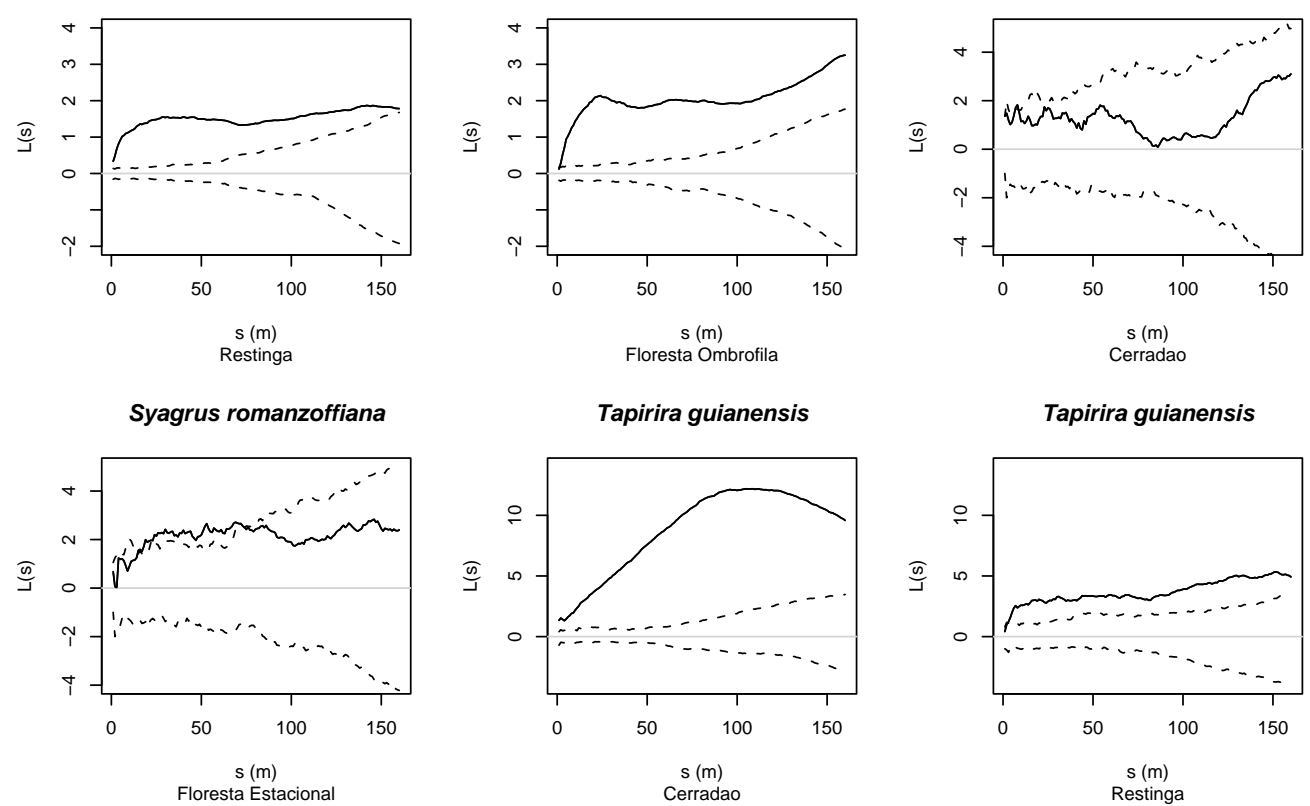

Figura 14 - Padrão espacial observado para as espécies coincidentes entre as quatro parcelas permanentes. a) Mapas das espécies; b) Padrão espacial observado para as espécies; as linhas tracejadas indicam os envelopes de confiança de 99,9\%, dentro dos quais se aceita a CAE 
escalas até $100 \mathrm{~m}$. O padrão espacial na Restinga apresenta grupos bem definidos a menos de $10 m$ de distâncias, e este fato é responsável pelo padrão sempre agregado nas distâncias seguintes.

\subsection{Discussão}

Para a maioria das espécies estudadas aqui, o padrão predominante foi o agregado. Em florestas tropicais, o padrão agregado é o mais comum (Hubbell 1979, Condit et al. 2000). Tal observação é explicada freqüentemente em função da capacidade limitada de dispersão de sementes, da disponibilidade de habitats e de condições microclimáticas favoráveis. O caráter agregado de florestas tropicais se reflete para suas espécies dominantes, segundo Armesto et al. (1986) e Collins \& Klahr (1991).

Padrões agregados são fortes evidências de limitação na capacidade de dispersão das espécies (Barot et al. 1999, Condit et al. 2000). Entre as espécies reconhecidamente zoocóricas e anemocóricas, não foram observadas grandes diferenças de um modo geral, exceto para Syagrus romanzoffiana. Para esta espécie, cujas sementes são procuradas por roedores, o padrão espacial predominante foi aleatório, exceto por uma escala de 25 a $75 \mathrm{~m}$ na Floresta Estacional, onde apresentou desvios em relação à CAE. No Cerradão, Copaifera langsdorffii, cujas sementes são dispersas por animais, e Vochysia tucanorum, cujas sementes são dispersas pelo vento, apresentaram agregação pronunciada em todas as escalas (figura 9). Para Euterpe edulis, que produz grande quantidade de sementes e que também são procuradas pela fauna, o padrão agregado em todas as escalas também foi observado. Condit et al. (2000) não encontraram resultados significativos nos seus estudos na Ilha de Barro Colorado (Costa Rica), quando tentaram observar os padrões de espécies dispersas por animais e de espécies que não apresentavam esta associação.

Diferenças no padrão espacial de espécies de dossel e sub-bosque também não foram observadas de modo geral. Embora espécies integrantes do sub-bosque das florestas estudadas, como Metrodorea nigra em Caetetus, tenham apresentado níveis tímidos de agregação, outras espécies também de sub-bosque, como Xylopia aromatica, 
em Assis, e Amaioua intermedia, na Ilha do Cardoso, apresentaram padrões agregados acentuados. De modo geral, a maioria das espécies deste estudo são integrantes do dossel, e o seu nível de agregação variou bastante conforme cada caso.

A dinâmica de florestas tropicais está intimamente ligada também à dinâmica de clareiras (Grau 2000). Espécies com diferentes preferências em relação à qualidade de luz incidente não mostraram diferenças de modo que fosse possível identificar relações do tipo causa e efeito. Espécies pioneiras e oportunistas aproveitam as brechas no dossel da floresta para explorar os novos recursos abertos em função da queda das árvores, especialmente maior luminosidade e maior temperatura (Leemans 1991, Grau 2000). Padrões agregados para espécies pioneiras, na escala das clareiras, são esperados. Espécies que preferem luz difusa ou necessitam de sombra ao longo do seu ciclo de vida (espécies esciófitas), como Amaioua intermedia, Euterpe edulis (sobretudo em estágios iniciais de vida), Trichilia clausenii e Aspidosperma polyneuron, apresentaram padrões agregados. Espécies que crescem a pleno Sol (heliófitas), como Copaifera langsdorfii, Ocotea corymbosa, Xylopia aromatica e Vochysia tucanorum, espécies dominantes no Cerradão de Assis, também apresentaram padrões agregados em todas as escalas. Apenas para Metrodorea nigra, em Caetetus, um padrão aleatório foi notado a partir de 75 $m$ de distâncias.

No Cerradão, as quatro espécies de maior densidade apresentaram características comuns: todas são heliófitas, e todas apresentaram padrões agregados em todas as escalas (figura 9). O comportamento da curva da Função K de Ripley foi bastante semelhante para Metrodorea nigra, Copaifera langsdorffii e Vochysia tucanorum, com "picos" de agregação claros em distâncias próximas a $75 \mathrm{~m}$. Estas três espécies integram o dossel do Cerradão. A espécie Xylopia aromatica é típica do sub-bosque desta formação florestal. Seu padrão observado, embora fortemente agregado, não apresenta níveis mais pronunciados de agregação em nenhuma escala detemrinada, mas um padrão crescente de agregação até a escala de $160 \mathrm{~m}$. A semelhança no padrão espacial das três espécies de dossel permite concluir que elas são responsáveis pela configuração espacial do topo do Cerradão. A Função K bivariada (figura 13) mostrou dependência espacial entre 
Copaifera langsdorffii e Ocotea corymbosa. Ambas as espécies são descritas na literatura como semidecíduas.

Na Floresta Estacional, duas espécies entre as quatro de maior densidade são reconhecidamente perenifólias: Metrodorea nigra e Aspidosperma polyneuron, embora a primeira seja espécie típica do sub-bosque, e a segunda componente do dossel. Estas duas espécies apresentaram dependência espacial (figura 13) em pequenas distâncias. A grande densidade de Metrodorea nigra (figura 10) certamente contribui para a caracterização do padrão espacial da formação como um todo, uma vez que o padrão espacial observado para a espécie se assemelha muito ao padrão espacial da comunidade (capítulo 2).

Na Floresta Ombrófila, três das quatro espécies de maior densidade apresentaram padrão espacial agregado em todas as escalas, salientado o caráter fortemente agregado do padrão espacial das árvores desta formação florestal. Fica evidente a importância do palmiteiro Euterpe edulis na comunidade, não só em função da sua dominância entre as espécies mais abundantes, como também do seu papel na composição do dossel e sub-bosque da floresta. O palmiteiro possui grande quantidade de frutos (atrativos para a fauna), intensa regeneração nos estratos inferiores da floresta e ainda auxilia na composição do dossel da floresta (Dias 1993). A espécie mostrou níveis de associação espacial com Guapira opposita e Garcinia gardenriana (figura 13). Estas duas espécies associadas ao palmiteiro também mostraram atração espacial entre si, o que é facilmente compreensível até observando a semelhança do mapa das árvores de cada espécie (figura 11).

Também na Restinga se observa a dominância de Euterpe edulis. Vale lembrar que grande parte da Ilha do Cardoso, especialmente na região mais montanhosa, é coberta por Floresta Ombrófila Densa, enquanto a Restinga aparece nas regiões originadas pela sedimentação marinha recente, no litoral da ilha. Assim como na Floresta Ombrófila, o palmiteiro também mostrou grande densidade na Restinga, e padrão agregado em todas as classes. Neis de agregação acentuados também foram observados para as outras três espécies estudadas. A espécie Amaioua intermedia é integrante do sub-bosque da 
Restinga, e seu padrão predominantemente agregado também pode fornecer indícios sobre a estrutura horizontal do estrato inferior da formação florestal. A espécie apresentou evidente associação espacial com Xylopia langsdorffiana (figura 13), em todas as escalas.

A espécie Euterpe edulis parece desempenhar papel importante na dinâmica da Floresta Ombrófila e da Restinga. O fato da espécie ser a mais abundante nas duas áreas já seria suficiente para justificar especial atenção. A espécie possui papel fundamental para a fauna, em razão do grande número de sementes e frutos produzidos, e para a composição de ambos os estratos da floresta, uma vez que é comum observar grande número de plantas e juvenis da espécie no sub-bosque dos remanescentes florestais. Por este motivo, a espécie é apontada como fundamental na recuperação de florestas secundárias (Dias 1993). O palmiteiro, em função da extração do palmito, é também espécie de grande apelo comercial (Anjos et al. 1998).

Analisando o padrão espacial de Euterpe edulis (figura 14), poucas diferenças são observadas entre as duas áreas: um padrão agregado em todas as escalas foi encontrado em ambas as florestas. Anjos et al. (2000), utilizando também a função K de Ripley (e uma escala de distâncias semelhante à utilizada no presente estudo) para estudar o padrão da espécie em Blumenau, sul do Brasil, encontraram um padrão predominantemente agregado até $100 \mathrm{~m}$ de distâncias. Uma forte tendência à regularidade foi notada para distâncias maiores (Anjos et al. 2000). Tal observação dos autores, entretanto, pode apresentar certo viés nas distâncias maiores em função do tamanho da área de estudo $(160 \times 320 \mathrm{~m})$ e da escolha da escala de distâncias (160 m, e não metade do lado menor da área de estudo).

Tomando como exemplo o padrão espacial de Euterpe edulis na Floresta Ombrófila e na Restinga, algumas considerações relevante spodem ser feitas sobre a autoecologia da espécie. A observação do comportamento semelhante de Euterpe edulis nas duas formações florestais reforça a importância da sua produção de frutos, sua capacidade de regeneração nos diferentes estratos da floresta, e sua dispersão de sementes.

As duas outras espécies coincidentes estudadas aqui mostraram padrões espaciais distintos. O padrão espacial do jerivá (Syagrus romanzoffiana) foi diferente nas 
duas florestas onde ocorre: enquanto no Cerradão a espécie apresentou padrão aleatório em todas as escalas, na Floresta Estacional a espécie apresentou ligeira agregação em distâncias menores que $100 \mathrm{~m}$. A espécie é classificada como pioneira (Lorenzi 1992), e segundo a literatura prefere solos úmidos. A espécie, assim como Euterpe edulis, produz grande quantidade de frutos, tornando-se assim uma espécie atrativa para dispersores.

Para Tapirira guianensis, embora o padrão agregado para todas as escalas tenha sido encontrado nas duas áreas de estudo, níveis de agregação diferentes foram observados. Um padrão mais complexo de agregação, com grupos de diversos tamanhos, foi observado para a espécie no Cerradãos. Na literatura, Tapirira guianensis é descrita como espécie que prefere solos úmidos (Lorenzi 1992).

De maneira geral, assume-se que o padrão espacial seja resultado dos processos ecológicos e das variáveis abióticas de cada bioma. Entre os processos ecológicos mais importantes estão a competição e a síndrome de dispersão de sementes. A competição interespecífica, especialmente em florestas livres de grandes perturbações, conduz o padrão espacial das árvores em direção à regularidade (Sterner et al. 1986, Kenkel et al. 1989, Condit et al. 1992, Batista 1994, Haase et al. 1997), embora seus efeitos possam variar bastante segundo suas características ecológicas.

As espécies incluídas neste estudo são as mais abundantes em cada formação florestal. Em razão da sua densidade, eventuais fenômenos como inibição entre as árvores de dossel (como resultado da competição por luz) são pouco evidentes (Batista 1994, John et al 2002).

A dinâmica do dossel de florestas tropicais é responsável por grande parte dos processos ecológicos que mantêm o bioma, como regeneração (Leemans 1991), disponibilidade de habitats (Harms et al. 2001) e de recursos, especialmente luz e nutrientes no solo (Grau 2000). A própria fisionomia conhecida como mosaico vegetacional, caracterizada por manchas de espécies dominantes, é reflexo direto da dinâmica do dossel (Batista 1994). O tamanho das aberturas no dossel e o padrão espacial das árvores no estrato inferior são preponderantes para a definição do padrão agregado e do tamanho dos grupos (Batista 1994, Grau 2000). 
A associação positiva entre as espécies dominantes em cada área, descrita através da função $\mathrm{K}$ bivariada, sugere que a competição entre tais espécies é baixa. Nas quatro áreas de estudo, as espécies dominantes, em sua maioria integrantes do dossel, possuem características ecológicas semelhantes, sobretudo em relação à tolerância a luz e deciduidade. Tendo nichos em comum, seria razoável supor que a competição tivesse efeitos acentuados (Haase et al. 1996) sobre o arranjo espacial das mesmas, o que não ocorre principalmente em razão da sua densidade.

A síndrome de dispersão de sementes pode afetar o padrão espacial das espécies principalmente em relação à escala de distâncias nas quais os agrupamentos são definidos (Janzen 1970, Connell 1978, Augspurger 1983, Houle 1992). A concentração das árvores em curtas distâncias ocorreria em função da limitação na capacidade de dispersão (Hubbell 1979, Condit et al. 2000, Grau 2000), enquanto espécies com mecanismos mais elaborados de dispersão de sementes, através do vento ou de animais, teriam padrões espaciais diferentes em distâncias maiores (Janzen 1970, Connell 1978). Nesta pesquisa, espécies zoocóricas, como Copaifera langsdorffii, Euterpe edulis e Syagrus romanzoffiana apresentaram padrões distintos entre si, com agregação acentuada em distâncias superiores a $15 \mathrm{~m}$ mas comportamentos distintos das curvas da função $\mathrm{K}$ de Ripley. A variação do padrão espacial destas espécies, especialmente das duas últimas, presentes com grande densidade em duas formações florestais distintas, pode ocorrer em função da densidade de dispersores.

O grau de heterogeneidade do ambiente (Condit et al. 2000), a disponibilidade de habitats (Harms et al. 2001), a caracterização do solo, relevo e regime de luz (Grau 2000, Harms et al. 2001, Day et al. 2003, Schwarz et al. 2003, Barot et al. 2003) podem influenciar a vegetação como um todo, assim como as suas espécies dominantes. Diferenciar claramente variáveis bióticas das abióticas não é tarefa simples na prática, uma vez que elas estão intimamente relacionadas. A presença de nutrientes no solo, a temperatura e a quantidade de luz são condicionados pela queda de árvores e abertura de clareiras no dossel (Grau 2000). O padrão espacial de algumas espécies deste estudo pode refletir algumas variáveis abióticas, especialmente solo e relevo. A ausência 
de árvores de Xylopia aromatica em uma região da parcela permanente no Cerradão, o padrão espacial das espécies da Floresta Ombrófila e o padrão espacial de Amaioua intermedia e Xylopia langsdorffiana na Restinga são bons exemplos.

\subsection{Conclusões}

O padrão espacial das espécies acompanhou, em linhas gerais, o padrão espacial das comunidades. Padrões agregados foram encontrados para a maioria das espécies em questão, o que ressalta a característica de manchas na vegetação, comum em florestas tropicais. Nestas manchas encontra-se grupos bem definidos de árvores, em sua maioria de espécies dominantes.

Quando comparados os padrões espaciais de espécies presentes em diferentes formações florestais, pequenas diferenças foram observadas, embora ainda seja difícil identificar claramente a sua razão. Assume-se que características intrínsecas àquelas espécies, como sua fenologia, síndromes de dispersão e polinização, estratégias de ocupação de habitats disponíveis e potencial competitivo possam explicar seu comportamento, no que se refere ao padrão espacial, frente a ambientes tão diferentes. As características abióticas e a própria composição das comunidades podem influenciar no modo de ocupar o espaço horizontal da floresta por tais espécies. 


\section{CONCLUSÕES GERAIS}

Padrões agregados foram predominantes tanto para as florestas de modo geral (o padrão geral em cada formação florestal) quanto para suas espécies mais abundantes. Dizer que o padrão agregado foi encontrado para a maioria dos casos não significa que o padrão seja igual em todos. De fato, diferenças relevantes no padrão observado foram notadas para os diversos conjuntos analisados.

Árvores tropicais tendem, de maneira geral, a padrões agregados (Hubbell 1979), contribuindo para a caracterização do que se chama de mosaico vegetacional, especialmente em razão do grande número de sementes e plântulas nas áreas próximas da árvore parental, e do grau de heterogeneidade de florestas tropicais. Uma paisagem marcada por diferentes manchas de solo, diferenças de relevo, condições microclimáticas, complexa estrutura vertical da floresta, dinâmica de clareiras e disponibilidade de microhabitats é comum em florestas tropicais (Barot et al. 1999, Condit et al. 2000, Grau 2000, Harms et al. 2001), e tais características provêm condições para que as árvores estejam agrupadas em manchas. Os resultados obtidos nesta pesquisa são coerentes com tais argumentos citados na literatura.

Segundo Barot et al. (1999) e Condit et al. (2000), testar a veracidade das teorias de Janzen (1970), Connell (1978) e Hubbell (1979) consiste em estudar o padrão espacial de jovens e adultos, e a relação de depedência espacial entre eles. Analisando o padrão espacial por classes de tamanho, foi possível observar que as árvores das classes menores (onde provavelmente estão incluídas as árvores jovens) mostram acentuada agregação, e que árvores de classes maiores apresentam tendência à padrões aleatórios. Níveis de atração evidentes (dependência espacial) entre as árvores jovens e adultas reforçam tal posição. Janzen (1970, Connell (1978) e Hubbell (1979) afirmam 
que a agregação de árvores jovens e sua afinidade com árvores adultas é resultado direto da limitada capacidade de dispersão, que faz com que a maioria das sementes e frutos produzidos fique no solo próximo à árvore de origem. Processos ecológicos dependentes da densidade, especialmente competição, diminuiríam a densidade dentro de tais conforme as árvores fossem crescendo, diluindo este padrão agregado em direção a padrões aleatórios.

O padrão espacial das espécies mais abundantes em cada formação florestal refletiu o padrão espacial observado para todas as árvores em cada parcela permanente. Tal resultado era esperado, uma vez que as quatro espécies no topo da tabela de abundância reúnem, via de regra, aproximadamente 30\% das árvores em cada floresta.

A complexidade da floresta tropical, onde atuam simultaneamente diversos processos ecológicos, e em que se pese a importância de fatores abióticos na definição da comunidade vegetal, muitas vezes torna difícil identificar claramente quais fatores são mais influentes. Os resultados obtidos através das análises do padrão espacial das espécies individualmente permitem apontar evidências de quais fatores, em cada caso, podem ser mais importantes, especialmente em função da identificação da escala de distâncias em que se observa o padrão espacial das árvores.

Vale ressaltar que algumas espécies em particular parecem desempenhar papéis essenciais na dinâmica das florestas das quais fazem parte. Destaque para o palmiteiro (Euterpe edulis), espécie mais abundante tanto na Floresta Ombrófila Densa Submontana quanto na Restinga, e que possui presença marcante tanto no subbosque, sob a forma de árvores regenerantes, quanto no dossel. Merecem menção ainda Metrodorea nigra, típica do sub-bosque da Floresta Estacional e espécie-chave na estrutura daquela floresta, Tapirira guianensis, espécie comum ao Cerradão e à Restinga, e Syagrus romanzoffiana, que assim como o palmiteiro, possui grande importância para a fauna.

Fica evidente também o potencial de uso da Função K de Ripley para estudos sobre o padrão espacial. Sua robustez e suas ferramentas permitem investigar uma série de questões de relevante interesse em ecologia florestal, especialmente na questão 
da detecção do padrão espacial em diferentes escalas, na análise de padrões espaciais observados comparando com modelos (como o modelo de Completa Aleatoriedade Espacial), e nas análises bivariadas, que avaliam a independência espacial entre grupos de árvores (classes de diâmetro ou espécies individualmente, neste estudo).

Os resultados aqui apresentados devem fornecer suporte a diversos outros estudos, inclusive dentro do próprio Projeto "Biota Parcelas Permanentes", e no cenário de pesquisas científicas em ecologia de populações arbóreas em florestas tropicais. O padrão espacial em cada formação, bem como das suas espécies dominantes, foi descrito. Esta pesquisa forcene subsídios para inúmeros estudos, especialmente no que se trata de fisiologia das espécies, fenologia, dispersão de sementes e autoecologia das espécies arbóreas. 


\section{Referências Bibliográficas}

ANJOS, A.; COUTO, H.T.Z.; BATISTA, J.L.F.; REIS, A. Análise do efeito de um manejo em regime de rendimento sustentável sobre o padrão de distribuição espacial do palmiteiro (Euterpe edulis Martius), utilizando a função K de Ripley. Revista Árvore, v.22, p.215-225, 1998.

ARMESTO, J.J.; MITCHELL, J.D.; VILLAGRAN, C. A comparison of spatial patterns of trees in some tropical and temperate forests. Biotropica, v.8, p.1-11, 1986.

AUGSPURGER, C.K. Offspring recruitment around tropical trees: changes in cohort distance with time. Oikos, v.40, p.189-196, 1983.

AUGSPURGER, C.K. Seedling survival of tropical tree species: interactions of dispersal distance, light-gaps and pathogens. Ecology, v.65, p.1705-1712, 1984.

BARBOSA, A.R.; YAMAMOTO, K.; VALIO, I.F.M. Effect of light and temperature on germination and early growth of Vochysia tucanorum Mart., Vochysiaceae, in cerrado and forest soil under differente radiation levels. Revista Brasileira de Botânica, v.22, p.275-280, 1999.

BAROT, S.; GIGNOUX, J.; MENAUT, J. Demography of a savanna palm tree: predictions from comprehensive spatial pattern analyses. Ecology, v.80, p.1987-2005, 1999. 
BATALHA, M.A.; MANTOVANI, W. Floristic composition of the cerrado in the Péde-Gigante Reserve (Santa Rita do Passa Quatro, Southeastern Brazil). Acta Botanica Brasilica, v.15, p.289-304, 2001.

BATISTA, J.L.F. Spatial dynamics of trees in a brazilian atlantic tropical forest under natural and managed conditions. Seattle, 1994. 392 p. Thesis (Ph.D.) - University of Washington.

BATISTA, J.L.F.; MAGUIRE, D.A. Modelling the spatial structure of tropical forests. Forest Ecology and Management, v.110, p.293-314, 1998.

BALVANERA, P.; LOTT, E.; SEGURA, G.; SIEBE, C.; ISLAS, A. Patterns of $\beta$-diversity in a mexican tropical dry forest. Journal of Vegetation Science, v.13, p.145-158, 2002

BENJAMIN, L. Experimental discrimination between contrasting models of neighbourhood competition. Journal of Ecology, v.81, p.417-423, 1993.

BERTANI, D.F. Análise da estrutura e dinâmica de uma comunidade de espécies arbóreas em um fragmento de floresta ribeirinha, Ipeúna, SP. Piracicaba, 2000. 70 p. Tese (Mestrado), Escola Superior de Agricultura Luiz de Queiroz, Universidade de São Paulo.

BRANDO, P.M; DURIGAN, G. Changes in cerrado vegetation after disturbance by frost, São Paulo State, Brazil. Plant Ecology (no prelo).

BUSING, R.T. Composition, structure and diversity of cove forest stands in the Great Smoky Mountains: a patch dynamcis perspective. Journal of Vegetation Science, v.9, p.881-890, 1998.

CAMARERO, J.J.; GUTIÉRREZ, E.; FORTIN, M. Spatial pattern of subalpine forestalpine grassland ecotones in spanish central Pyrenees. Forest Ecology and Management, v.134, p.1-16, 2000. 
CLARK, D.A.; CLARK, D.B. Spacing dynamics of a tropical rainforest tree: evaluation of the Janzen-Connell model. American Naturalist, v.124, p.769-788, 1984.

COLLINS, S.L.; KLAHR, S.C. Tree dispersion in oak-dominated forests along an environmental gradient. Oecologia, v.86, p.471-477, 1991.

CONDIT, R.; HUBBELL, S.P.; FOSTER, R.B. Recruitment near conspecific adults and the mainenance of tree and shrub diversity in a neotropical forest. American Naturalist, v.140, p.261-286, 1992.

CONDIT, R.; HUBBELL, S.P.; FOSTER, R.B. Density dependence in two understory tree species in a neotropical forest. Ecology, v.75, p.671-680, 1994.

CONDIT, R.; ASHTON, P.; BAKER, P. et al. Spatial Patterns in the distribution of tropical tree species. Science, v.288, p.1414-1418, 2000.

CONDIT, R.; WATTS, K.; BOHLMAN, S.A.; PÉREZ, R.; FOSTER, R.B.; HUBBELL, S.P. Quantifying the deciduousness of tropical forest canopies under varying climates. Journal of Vegetation Science, v.11, p.649-658, 2000.

CONDIT, R.; PITMAN, N.; LEIGH JUNIOR., E.G. et al. Beta-diversity in tropical forest trees. Science, v.295, p.666-669, 2002.

CONNELL, J.H. Diversity in tropical rain forests and coral reefs. Science, v.199, p.1302-1310, 1978.

COOMES, D.A.; REES, M.; TURNBULL, L. Identifying aggregation and association in fully mapped spatial data. Ecology, v.80, p.554-565, 1999.

CUNHA. U.S. Análise da estrutura espacial horizontal de uma floresta de terra firme da Amazônia. Curitiba, 2003. 126 p. Tese (Doutorado), Universidade Federal do Paraná.

DALE, M.R.T.; POWELL, R.D. A new method of characterizing point patterns in plant ecology. Journal of Vegetation Science, v.12, p.609-620, 2001. 
DAY, K.J.; JOHN, E.A.; HUTCHINGS, M.J. The effects of heterogeneous nutrient supply on yield, intensity of competition and root placement patterns in Briza media and Festuca ovina. Functional Ecology, v.17, p.454-463, 2003.

DIGGLE, P.J. Statistical analysis of spatial point patterns. London: Academic Press. 1983. 272p.

DURIGAN, G.; FRANCO, G.A.D.C.; SAITO, M.; BAITELLO, J.B. Estrutura e diversidade do componente arbóreo da floresta na estação ecológica dos Caetetus, Gália, SP. Revista Brasileira de Botânica, v.23, p.371-383, 2000.

EDMAN, M.; JONSSON, B.G. Spatial pattern of downed logs and wood-decaying fungi in an old-growth Picea abies forest. Journal of Vegetation Science, v.12, p.609620, 2001.

GETIS, A.; FRANKLIN, J. Second-order neighbourhood analysis of mapped point patterns. Ecology, v.68, p.473-477, 1987.

GRAU, H.R. Regeneration patternos of Cedrela lilloi (Meliaceae) in northwestern Argentina subtropical montane forests. Journal of Tropical Ecology, v.16, p.227$242,2000$.

GOREAUD, F.; LOUREAU, M.; MILLIER, C. Spatial structure and the survival of an inferior competitor: a theorical model of neighbourhood competition in plants. Ecological Modelling, v.158, p.1-19, 2002.

HAASE, P. Spatial pattern analysis in ecology based on Ripleyt's K function: introduction and methods of edge correction. Journal of Vegetation Science, v.6, p.575-582, 1995.

HAASE, P. Can isotropy vs. anisotropy in the spatial association of plant speceis reveal physical vs. biotic facilitation? Journal of Vegetation Science, v.12, p.127-136, 2001. 
HAASE, P; PUGNAIRE, F.L.; CLARK, S.C.; INCOLL, L.D. Spatial patterns in two-tired semi-arid shrubland in southeastern Spain. Journal of Vegetation Science, v.7, p.527-534, 1996.

HAASE, P.; PUGNAIRE, F.; CLARK, S.C.; INCOLL, L.D. Spatial pattern in Anthyllis cytisoides shrubland on abandoned land in southeastern Spain. Journal of Vegetation Science, v.8, p.627-634, 1997.

HARMS, K.E.; CONDIT, R.; HUBBELL, S.P., FOSTER, R.B. Habitat associations of trees and shrubs in a 50ha neotropical forest plot. Journal of Vegetation Science, v.11, p.801-812, 2001.

HE, F.; DUNCAN, R.P. Density-dependence effects in tree survival on a old-growth Douglas fir forest. Journal of Ecology, v.88, p.676-688, 2000.

HOULE, G. Spatial relationship between seed and seedling abundance and mortality in a deciduous forest of north-eastern North Amercia. Journal of Ecology, v.80, p.99-108, 1992.

HUBBELL, S.P. Tree dispersion, abundance and diversity in a tropical dry forest. Science, v.203, p.1299-1309, 1979.

JANZEN, D.H. Herbivores and the number of tree species in tropical forests. American Naturalist, v.104, p.501-528, 1970.

JOHN, R.; DATTARAJA, H.S.; SURESH, H.S; SUKUMAR, R. Density-dependenbce in common tree species in a tropical dry forest in Mudumalai, Southern India. Journal of Vegetation Science, v.13, p.45-56, 2002.

KENKEL, N.C. Pattern of self-thinning in jack pine: testing the random mortality hypothesis. Ecology, v.69, p.1017-1024, 1988.

KENKEL, N.C. Modelling markovian dependence in populations of Aralia nudicaulis. Ecology, v.74, p.1700-1706, 1993. 
KENKEL, N.C.; HOSKINS, J.A; HOSKINS, W.D. Local competition in a naturally established jack pine stand. Canadian Journal of Botany, v.67, p.2630-2635, 1989.

KUULUVAINEN, T.; ROUVINEN, S. Post-fire understorey regeneration in boreal Pinnus sylvestris forest sites with different fire histories. Journal of Vegetation Science, v.11, p.801-812, 2000.

LEEMANS, R. Canopy gaps and establishment patterns of spruce (Picea abies (L.) Karst.) in two old-growth coniferous forests in central Sweden. Vegetatio, v.93, p.157-165, 1991.

LEGENDRE, P. Spatial autocorrelation: trouble or new paradigm? Ecology, v.74, p.1659-1673, 1993.

LEGENDRE, P.; FORTIN, M. Spatial pattern and ecological analysis. Vegetatio, v.80, p.107-138, 1989.

LOTWICK, H.W.; SILVERMAN, B.W. Methods for analysing spatial processes of several types of points. Journal of the Royal Statistical Society, v.44, p.406-413, 1982.

MAAS, P.J.M.; KAMER, H.M.; JUNIKKA,L.; MELLO-SILVA,R.; RAINER,H. Annonnaceae from central-eastern Brazil. Rodriguésia, v.52, p.65-98, 2001.

MIYADOKORO, T.; NISHIMURA, N.; YAMAMOTO, S. Populatiuon structure and spatial patterns of major trees in a subalpine old-growth coniferous forest, central Japan. Forest Ecology and Management, v.182, p.259-272, 2003.

NICOTRA, A.B. Sex ratio and spatial distribution of Siparuna grandiflora, a tropical dioecious shrub. Oecologia, v.115, p.102-113, 1998.

PÉLISSIER, R. Tree spatial patterns in three contrasting plot of a southern Indian tropical moist evergreen forest. Journal of Tropical Ecology, v.14, p.1-16, 1998. 
PIELOU, R.C. The use of plant-to-neighbour distances for the detection of competition. Journal of Ecology, v.50, p.357-367, 1962.

PHILIPS, D.T.; MACMAHON, J.A. Competition and spacing patterns in desert shrubs. Journal of Ecology, v.69, p.97-115, 1981.

PLOTKIN, J.B.; POTTS, M.D.; LESLIE, N.; MANOKARAN, N.; LAFRANKIE, J.L.; ASTON, P.S. Species-area curves, spatial aggregation and habitat specialization in tropical forests. Journal of Theoretical Biology, v.207, p.81-89, 2000.

PYKE, C.R.; CONDIT, R.; AGUILAR, S.; LAO, S. Floristic compostion accross a climatic gradient in a neotropical lowland forest. Journal of Vegetation Science, v.12, p.553-566, 2001.

PUGNAIRE, F.I.; HAASE, P. Facilitation between higher plant species in a semiarid environment. Ecology, v.77, p.1420-1426, 1996.

REES, M.; CONDIT, R.; CRAWLEY, M.; PACALA, S.; TILMAN, D. Long-term studies of vegetation dynamics. Science, v.293, p.650-655, 2001.

RESENDE, J.C.F.; KLINK, C.A.; SCHIAVINI, I. Spatial heterogeneity and its influence on Copaifera langsdorffii Desf. (Caesalpiniaceae). Brazilian Archives of Biology and Technology, v.46, p.405-414, 2003.

RIPLEY, B.D. Modelling spatial patterns. Journal of the Royal Statistic Society, v.39, p.172-212, 1977.

RIPLEY, B.D. Spectral Analysis and the analysis of pattern in plant communities. Journal of Ecology, v.66, p.965-981, 1978.

RIPLEY, B.D. Tests of 'randomness' for spatial point patterns. Journal of the Royal Statistic Society B, v.41, p.368-374, 1979.

RIPLEY, B.D. Spatial statistics. New York: John Wiley. 1981. 183p. 
ROBERTSON, K.M.; AUGSPURGER, C.K. Geomorphic processes and spatial patterns of primary forest succession on the Bogue Chitto River, USA. Journal of Ecology, v.87, p.1052-1063, 1999.

SAMPAIO, D. Levantamento das espéies arbóreas de uma parcela permanente em floresta de restinga do parque estadual da llha do Cardoso, município de Cananéia / São Paulo. 2003. 161 p. Tese (Mestrado), Escola Superior de Agricultura Luiz de Queiroz, Universidade de São Paulo.

SCHWARZ, P.A; FAHEY, T.J.; MCCULLOCH, C.E. Factors controlling spatial variation of tree species abundance in a forested landscape. Ecology, v.84, p.1862-1878, 2003.

STOYAN, D.; STOYAN, H. Improving ratio estimators of second order point processes characteristics. Scandinavian Journal of Statistics, v.27, p.641-656, 2000.

VILELA, E.A.; OLIVEIRA-FILHO, A.T.; CARVALHO, D.A.; GUILHERME, F.A.G.; APPOLINARIO, V. Caracterização estrutural de floresta ripária do Alto Rio Grande, em Madre de Deus de Minas, MG. Revista Cerne, v.6, p.41-54, 2000. 